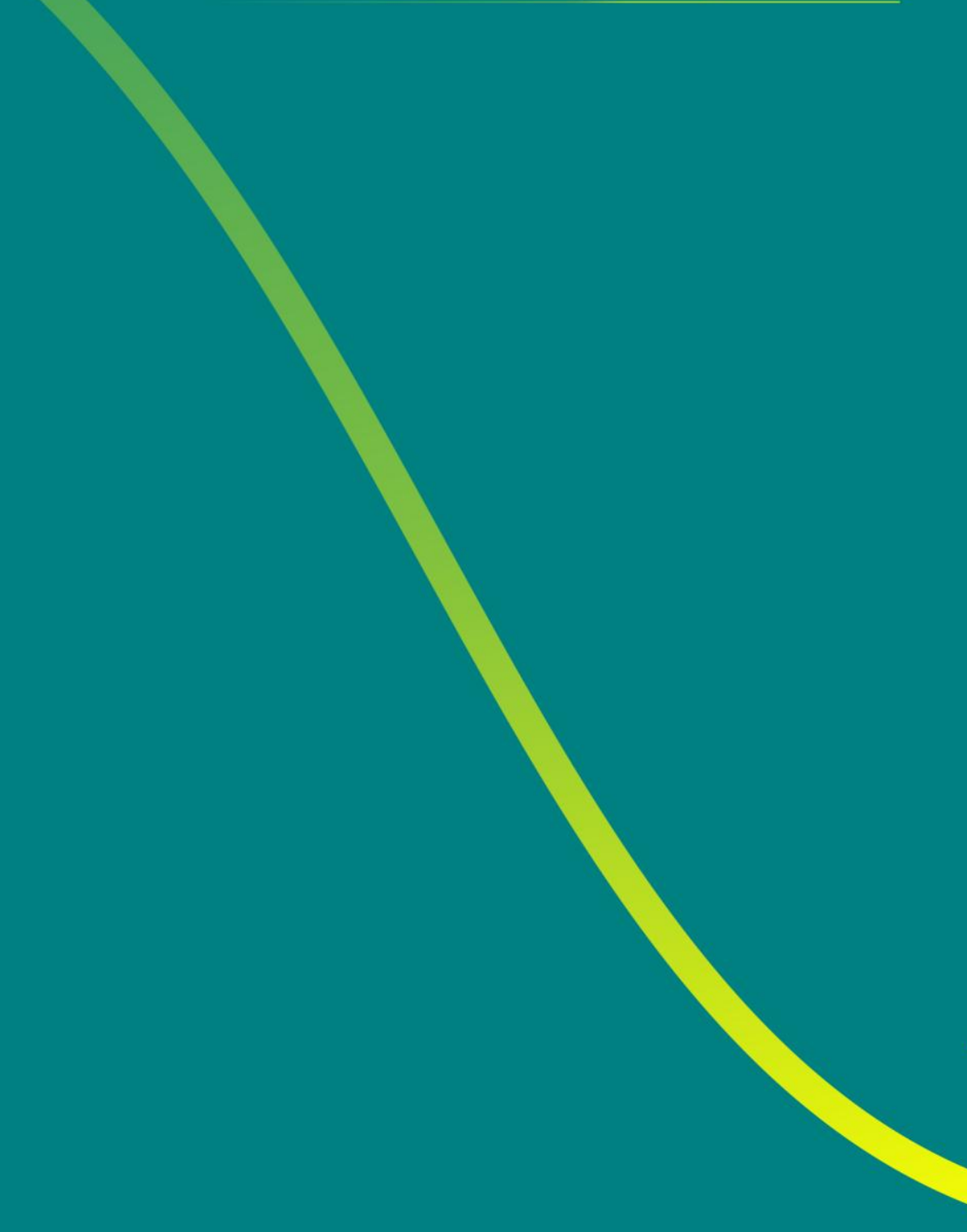

BUKU AJAR BAHASA INDONESIA MISD

(Teori Sastra dan Linguistik)

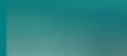

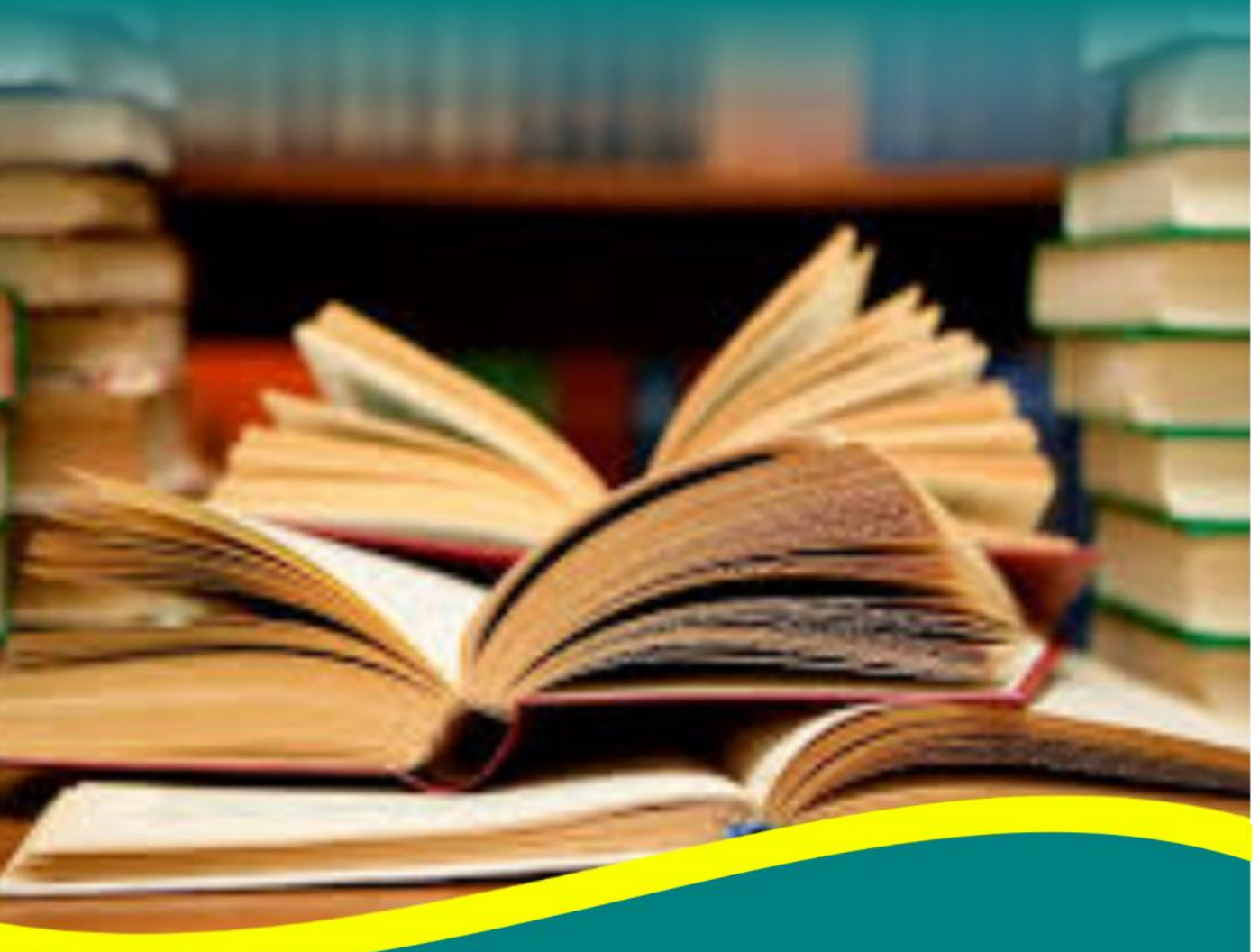

PROGRAM STUDI PENDIDIKAN GURU MADRASAH IBTIDAIYYAH FAKULTAS AGAMA ISLAM UNIVERSITAS MUHAMMADIYAH SIDOARJO 2017 


\title{
BUKU AJAR \\ BAHASA INDONESIA MI/SD
}

\author{
Penulis
}

Ruli Astuti,S.S., M.Pd.I

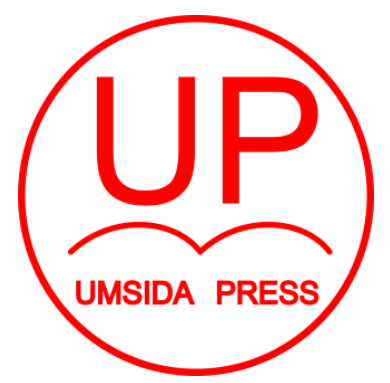

Diterbitkan oleh

\section{UMSIDA PRESS}

Jl. Mojopahit 666 B Sidoarjo

ISBN: 9789793401690

Copyright@2017.

Authors

All rights reserved 


\section{BUKU AJAR}

\section{BAHASA INDONESIA MI/SD}

\section{Penulis :}

Ruli Astuti,S.S., M.Pd.I

\section{ISBN :}

9789793401690

\section{Editor :}

Septi Budi Sartika, M.Pd

M. Tanzil Multazam, S.H., M.Kn.

\section{Copy Editor :}

Fika Megawati, S.Pd., M.Pd.

\section{Design Sampul dan Tata Letak :}

Mochamad Nashrullah, S.Pd

\section{Penerbit :}

UMSIDA Press

\section{Redaksi :}

Universitas Muhammadiyah Sidoarjo

Jl. Mojopahit No 666B

Sidoarjo, Jawa TImur

\section{Cetakan pertama, Agustus 2017}

(C) Hak cipta dilindungi undang-undang

Dilarang memperbanyak karya tulis ini dengan suatu apapun tanpa ijin tertulis dari penerbit. 


\section{KATA PENGANTAR}

Puji syukur penulis panjatkan kehadirat Allah SWT atas rahmat, berkah, dan karuniaNya penyusunan buku ajar Bahasa Indonesia MI/SD dapat terselesaikan.

Buku ini disusun sebagai salah satu bahan ajar untuk menunjang pelaksanaan kegiatan perkuliahan. Dalam buku ini disajikan berbagai materi yang berkaitan dengan linguistik dan sastra yang mencakup konsep perkembangan bahasa, morfologi, fonologi, kesusastraan Indonesia dan apresiasi sastra. Buku ini dilengkapi dengan rangkuman materi dan soal evaluasi di tiap-tiap akhir bab sehingga memudahkan para mahasiswa dalam mendalami materi.

Penulis menyampaikan ucapan terima kasih yang sebesarbesarnya kepada unit LP3IK Universitas Muhammadiyah Sidoarjo yang telah memfasilitasi penerbitan buku ajar ini.

Penulis 


\section{DAFTAR ISI}

KATA PENGANTAR......................................................... i

DAFTAR ISI ............................................................

BAB I TEORI PEMEROLEHAN BAHASA PERTAMA

DAN PERKEMBANGAN BAHASA MANUSIA

A. Pengertian Bahasa ................................. 1

B. Pemerolehan Bahasa Pertama ......................... 8

C. Teori Pemerolehan Bahasa Pertama (B1) ....... 9

D. Perkembangan Bahasa Pada Anak ............... 14

BAB II RAGAM BAHASA INDONESIA
A. Pengertian Ragam Bahasa ................... 26
B. Ragam Bahasa Baku Dan Tidak Baku ... 28
C. Fungsi Bahasa Baku .......................... 30

BAB III MORFOLOGI BAHASA INDONESIA
A. Pengertian Morfologi ........................... 35
B. Morfem …........................................ 36
C. Identifikasi Morfem............................ 37
D. Jenis Morfem …................................. 38
E. Morfem Dasar, Bentuk Dasar,
Pangkal, Akar, Dan Leksem.......................... 40
F. Proses Morfemis .......................................... 42
G. Morf Dan Alomorf ...................................... 48

\section{BAB IV FONOLOGI BAHASA INDONESIA}

A. Pengertian Fonologi .............................. 53

B. Pengertian Dan Jenis Fonem …............. 55

C. Alofon ................................................. 57

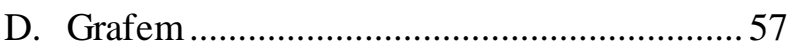

E. Klasifikasi Bunyi.............................................58 
BAB V KALIMAT
A. Pengertian Kalimat .......................................... 65
B. Jenis Kalimat.................................................. 66
C. Makna Kata ................................................... 76
D. Relasi Makna .............................................. 79
E. Pergeseran Makna Bahasa Indonesia ............ 83

BAB VI PARAGRAF
A. Pengertian Paragraf
B. Ciri Dan Komponen Paragraf........................ 90
C. Jenis Paragraf …………………..................... 93
D. Pengembangan Paragraf ................................. 96

\section{BAB VII SEJARAH DAN PERIODISASI SASTRA INDONESIA}
A. Pengertian Sastra ............................................ 106
B. Fungsi Sastra................................................ 107
C. Sejarah Sastra Indonesia.............................. 108
D. Periodisasi Sastra Indonesia ........................ 109

BAB VIII JENIS DAN BENTUK KARYA SASTRA
A. Jenis-Jenis Sastra........................................ 129
B. Unsur Karya Sastra Indonesia ..................... 130
C. Bentuk Karya Sastra.................................... 143
D. Resensi Karya Sastra ( Novel Dan Cerpen) 167

\section{BAB IX APRESIASI SASTRA}
A. Pengertian Apresiasi Sastra 176
B. Fungsi Apressiasi Sastra 178
C. Pendekatan Dalam Apresiasi Sastra 180
D. Aliran Dan Teori Apresiasi Sastra 185
E. Apresiasi Sastra Di Sekolah Dasar 187
F. Genre Karya Sastra Di Sekolah Dasar. 196 
DAFTAR PUSTAKA.................................................... 206

\section{BAB I}

\section{TEORI PEMEROLEHAN BAHASA PERTAMA DAN PERKEMBANGAN BAHASA MANUSIA}

\section{Tujuan Instruksional}

Mahasiswa mampu memahami dan menganalisis beberapa teori pemerolehan bahasa dan perkembangan bahasa manusia

\section{A. PENGERTIAN BAHASA}

Bahasa diartikan sebagai suatu sistem lambang bunyi yang bersifat arbitrer dan digunakan oleh sekelompok masyarakat untuk berinteraksi dan mengidentifikasikan diri (Chaer, 1994). Bahasa merupakan alat yang dipergunakan untuk membentuk pikiran dan perasaan, keinginan, serta perbuatan-perbuatan. Pendapat lain tentang bahasa juga dikemukakan oleh Kartono (1990) bahwa bahasa merupakan tanda atau simbol-simbol dari benda-benda, serta merujuk pada maksud-maksud tertentu. Kata-kata, kalimat, dan bahasa selalu menampilkan arti-arti tertentu. Sistem aturan bahasa terdiri dari fonologi (studi tentang sistem bunyi-bunyi bahasa), morfologi (studi yang berhubungan dengan ketentuan pengkombinasian morfem), sintaksis (mencakup kata-kata yang dikombinasukan untuk membentuk ungkapan maupun kalimat yang dapat diterima), semantik (berhubungan dengan makna dan kalimat), serta pragmatik. Menurut Dhieni (2008) bahasa memiliki beberapa karakteristik diantaranya: 
1. Sistematis, yang berarti bahasa merupakan suatu cara menggabungkan bunyi maupun tulisan yang teratur, standar, serta konsisten. Masing-masing bahasa memiliki tipe konsistensi yang berbeda-beda.

2. Arbitrer, artinya bahasa terdiri dari hubungan antara berbagai suara maupun visual, objek, gagasan. Masingmasing bahasa memiliki kata yang berbeda dalam memberikan simbol pada benda tertentu. Misalnya benda yang berbentuk rumah,dalam bahasa Indonesia ditandai dengan kata rumah, sedangkan dalam bahasa Inggris ditandai dengan kata house, dan dalam bahasa Jawa ditandai dengan kata omah.

3. Fleksibel, artinya bahasa dapat berubah-ubah seiring dengan perkembangan zaman, misalnya kosakata. Setiap terjadi perubahan zaman, perkembangan pengetahuan dan teknologi, kosakata akan terus bertambah. Kosakata tersebut terdiri dari kata-kata baru yang berkaitan dengan istilah teknologi dan ilmu pengetahuan lainnya. Selain itu berbagai singkatan dan jargon akan bermunculan dan menyebar di masyarakat luas.

4. Beragam, artinya bahasa memiliki beragam dialek dalam hal pengucapan. Variasi atau perbedaan dialek itu terjadi dalam pengucapan, kosakata, maupun sintaks. Pada awalnya perbedaan dialek terjadi karena adanya perbedaan faktor geografis, akan tetapi seiring perkembangan zaman perbedaa dialek bisa ditentukan oleh adanya kelompok sosial yang berbeda dalam suatu masyarakat.

5. Kompleks, artinya kemampuan berfikir dan bernalar ditentukan oleh adanya kemampuan dalam menggunakan 
bahasa yang menjelaskan berbagai konsep, ide yang diungkapkan. Meskipun bahasa bukanlah satu-satunya prasyarat dalam kemampuan berfikir, akan tetapi bahasa dapat membantu kemampuan berfikir karena keduanya berkembang bersama. Sebagai contoh, anak yang berusia 1,5 tahun belum memiliki kemampuan berbahasa yang baik akan tetapi mereka sudah memiliki kemampuan bernalar dan bisa diajak untuk berkomunikasi.

Selain memiliki karakteristik diatas, Chaer (2012) berpendapat bahasa memiliki ciri, diantaranya:

1. Bahasa merupakan sebuah sistem. Artinya bahasa terdiri dari beberapa unsur atau komponen yang secara teratur tersusun menurut pola dan membentuk satu kesatuan. Misalnya dalam contoh kalimat berikut:

a. Ayam itu memakan semua biji jagung.

b. Memakan itu ayam jagung semua biji.

Kalimat (a) memiliki pola dan aturan sistem Bahasa Indonesia yang benar dan bisa disebut sebagai kalimat Bahasa Indonesia. Sedangkan kalimat (b) tidak memiliki pola yang benar dan tidak sesuai aturan bahasa Indonesia yang benar maka kalimat tersebut bukanlah kalimat bahasa Indonesia.

Sebagai sebuah sistem bahasa bersifat sistemis dan sistematis. Sistemis artinya bahasa bahasa terdiri dari beberapa sub sistem atau sistem bawahan atau dengan kata lain bahasa bukanlah sistem tunggal. Sedangkan kata sistematik artinya bahasa tersusun menurut pola tertentu (tidak tersusun secara acak dan sembanrangan). Jenjang dari sistem linguistik ini lazim dikenal dengan nama tataran linguistik atau tataran bahasa. 
2. Bahasa berwujud lambang. Artinya bahasa dapat ditandai dengan lambang tertentu. Lambang ini menandai sesuatu secara konvensional, tidak secara alamiah dan langsung, misalnya gambar padi dan kapas dalam simbol Negara Pancasila melambangkan asas keadilan sosial. Lambang bahasa sebenarya bersifat arbitrer, misalnya warna kuning tidak selalu dilambangkan sebagai tanda adanya duka atau orang meninggal. Dalam konteks lain misalnya pertandingan sepak bola dan rambu lalu lintas warna kuning memiliki perbedaan makna.

3. Bahasa itu berupa bunyi, artinya bahasa merupakan sistem lambang bunyi. Adapun yang dimaksud dengan bunyi bahasa atau lambang bahasa merupakan bunyibunyi yang dihasilkan oleh alat ucap manusia, kecuali bunyi teriak, bersin, batuk, dengkuran. Bunyi teriakan, batuk, bersin meskipun berasal dari alat ucap manusia, akan tetapi tidak bisa disebut sebagai bunyi bahasa karena tidak bisa dikombinasikan dengan bunyi lain untuk menyampaikan pesan. Begitu juga dengan suara dengkuran, bunyi dengkuran terjadi karena tidak disadari dan tidak dapar menyampaikan pesan apapun.

4. Bahasa bersifat arbitrer, artinya tidak memiliki hubungan wajib antara lambang bahasa yang berwujud bunyi dengan pengertian yang dimaksud dalam lambang itu. Misalnya singa merupakan sejenis binatang yang berkaki empat dan juga buas. Kita tidak dapat menjelaskan mengapa binatang tersebut dilambangkan dengan bunyi 
[singa] kanapa tidak dilambangkan dengan bunyi [ayam], [ngais] atau lambang bunyi lainnya. Dalam bahasa Indonesia ada istilah penanda dan petanda. Penanda (signifiant) merupakan lambang bunyi sedangkan petanda (signify) merupakan konsep yang dikandungnya. Lambang yang berupa bunyi tersebut tidak memberi saran atau petunjuk apapun mengenai konsep yang diwakilinya atau dengan kata lain tidak ada hubungan antara signifiant dan signify.

5. Bahasa itu bermakna, artinya bahasa merupakan lambang yang mengacu pada suatu konsep, ide, atau pikiran. Lambang-lambang bunyi bahasa yang bermakna tersebut berupa satuan-satuan bahasa yang diwujudkan dalam morfem, kata, frasa, klausa, kalimat serta wacana.

6. Bahasa bersifat konvensional, artinya kekonvensionalan bahasa terletak pada kepatuhan para penutur bahasa dalam mengguankan lambang tersebut sesuai dengan konsep yang dilambangkannya.

7. Bahasa bersifat unik, artinya bahasa memiliki ciri khas yang spesifik yang tidak dimiliki oleh bahasa lain. Adapun ciri khas suatu bahasa bisa menyangkut sistem bunyi, pembentukan kata dan kalimat, dan sistem lainnya.

8. Bahasa bersifat universal, artinya ciri yang terdapat dalam suatu bahasa terdapat pula dalam bahasa lainnya. 
Ciri yang universal tentunya merupakan unsur bahasa yang umum yang dimiiki oleh beberapa bahasa, misalnya setiap bahasa memiliki satuan-satuan bahasa yang bermakna baik satuan berupa kata, frase, klausa, maupun kalimat.

9. Bahasa bersifat produktif, artinya meskipun unsrurunsur bahasa itu terbatas akan tetapi bisa dibuat satuansatuan bahasa yang jumlahnya tidak terbatas. Misalnya kita ambil contoh fonem bahasa Indonesia /t/, /p/, /a/, /i/ maka dari keempat fonem tersebut dapat dihasilkan satuan bahasa /p/-/i///t/-/a/ dan /t/-/a/-/p/-/i/.

10. Bahasa itu bervariasi, artinya bahasa yang digunakan oleh masyarakat dengan latar belakang budaya, profesi, tempat tinggal, serta lingkungan yang berbeda seringkali mengakibatkan adanya variasi atau ragam bahasa. Berkenaan dengan variasi bahasa, terdapat tiga istilah yang perlu diketahui yaitu idiolek, dialek, dan ragam. Idiolek yaitu ragam bahasa yang bersifat perseorangan. Dialek merupakan variasi bahasa yang digunakan oleh sekelompok orang di suatu tempat atau suatu waktu, misalnya dekenal adanya Bahasa Jawa dialek Tegal, dialek Kediri, dan sebagainya. Dialek bahasa berdasarkan tempat umumnya disebut sebagai dialek regional, dialek geografi, atau dialek areal. Sedangkan variasi bahasa yang digunakan berdasarkan waktu misalnya pada zaman Balai Pustaka, orde baru, dan sebagainya disebut sebagai dialek temporal atau kronolek. Yang dimaksud dengan idiolek yaitu ragam 
bahasa yang digunakan oleh sekelompok anggota masyarakat dengan status sosial tertentu.

11. Bahasa bersifat dinamis, artinya bahasa mengalami perubahan karena adanya perubahahan kehidupan yang berlangsung dalam masyarakat, misalnya di bidang sosial, politik, budaya, ilmu pengetahuan, dan sebagainya. Perubahan tersebut bisa saja terjadi pada selurh tataran baik fonologi, morfologi, sintaksis, semantik, maupun leksikon. Akan tetapi perubahan yang paling menonjol diantara tataran tersebut adalah bidang leksikon dan semantik. Hal ini bisa dilihat dari adanya perkembangan kata-kata baru yang muncul karena adanya perubahan budaya dan ilmu pengetahuan. Perubahan yang terjadi dalam suatu bahasa tidak hanya berupa pengembangan dan perluasan, akan tetapi adanya kemunduran karena adanya perubahan yang terjadi di masyarakat bahasa yang bersangkutan. Sebagai contoh banyak masyarakat yang tidak lagi menggunakan bahasanya dan menggunakan bahasa lain sehingga banyak bahasa daerah yang ditinggalkan oleh penuturnya terutama karena alasan sosial.

12. Bahasa berfungsi sebagai alat interaksi sosial, artinya bahasa digunakan sebagai alat untuk berkomunikasi dan berinteraksi. Interaksi yang dilakukan oleh manusia sebagain besar dilakukan dengan mengguankan bahasa, misalnya digunakan untuk 
meminta bantuan, melarang, memerintah orang lain dan sebagainya.

13. Bahasa merupakan identitas penuturnya, artinya bahasa dijadikan sebagai identitas individu, keompok, bahkan identitas suatu Negara.

\section{B. PEMEROLEHAN BAHASA PERTAMA}

Pemerolehan bahasa merupakan proses yang berlangsung di dalam otak anak ketika dia memperoleh bahasa pertamanya. Bahasa pertama ini disebut juga sebagai bahasa ibu. Bahasa pertama diperoleh melalui beberapa tahap dan setiap tahap berikutnya lebih mendekati tata bahasa dari bahasa orang dewasa. Menurut para ahli, tahaptahap ini sedikit banyaknya ada ciri kesemestaan dalam berbagai bahasa di dunia. Dardjowidjojo (2008) menyatakan bahwa pemerolehan bahasa anak (language acquistion) adalah proses penguasaan bahasa yang dilakukan oleh anak secara natural pada waktu ia belajar bahasa ibunya (native language). Keajaiban akan muncul ketika anak mulai mengucapkan kata pertamanya. Setelah kata pertama, kemudian akan muncul kata-kata yang lain, dan seterusnya. Jadi, bahasa sebagai alat komunikasi akan diperoleh manusia sejak lahir sampai usia lima tahun, yang dikenal dengan istilah pemerolehan bahasa. Dalam proses pemerolehan bahasa dikenal dengan suatu masa yang dinamakan critical period (periode kritis). Critical period merupakan periode yang mana penguasaan bahasa terjadi secara alami dan dilakukan tanpa sengaja. Pada proses ini 
anak menemukan bunyi atau kalimat yang didengarnya tanpa ada rasa takut salah.

\section{C.TEORI PEMEROLEHAN BAHASA PERTAMA (B1)}

Pemerolehan bahasa pada dasarnya berlangsung di dalam otak seorang anak saat memperoleh bahasa pertama atau bahasa ibu. Pemerolehan bahasa pertama pada dasarnya terjadi melalui dua proses, yaitu proses kompetensi dan performansi (Chaer, 2015). Proses penguasaan tata bahasa yang berlangsung secara tidak sadar disebut sebagai proses kompetensi. Proses kompetensi ini menjadi syarat untuk terjadinya proses performansi. Proses performansi terdiri dari dua buah proses, yaitu proses pemahaman dan juga penerbitan atau proses menghasilkan kalimat. Proses pemahaman melibatkan kemampuan mengamati dan mempersepsi kalimat yang didengar. Sedangkan proses penerbitan melibatkan kemampuan mengeluarkan kalimat-kalimat sendiri. Apabila kedua proses ini telah dikuasai oleh anakanak maka akan menjadi kemampuan linguistik anak tersebut. Beberapa teori yang menjelaskan tentang pemerolehan bahasa pertama diataranya:

a. Hipotesis nurani (Innateness hypotesis)

Teori hipotesis nurani lahir dari beberapa pengamatan yang dilakukan oleh beberapa pakar terhadap pemerolehan bahasa anak-anak, hasil pengamatan tersebut diantaranya:

1. Semua anak yang normal akan memperoleh dan menguasai bahasa ibunya asalkan mereka 
diperkenalkan pada bahasa ibunya itu. Artinya, mereka tidak diasingkan dari kehidupan keluarganya

2. Pemerolehan bahasa tidak secara langsung berhubungan dengan tinggi rendahnya IQ. Artinya, baik anak yang cerdas maupun tidak cerdas akan memperoleh bahasa itu.

3. Kalimat yang didengar anak sering kali tidak gramatikal, tidak lengkap dan jumlahnya sedikit, namun pada akhirnya anak dapat menguasainya

4. Bahasa hanya dikuasai manusia, tidak dapat diajarkan pada makhluk lainnya

5. Proses pemerolehan bahasa pada anak-anak dimanapun akan sesuai dengan proses pematangan jiwanya

6. Struktur bahasa yang awalnya rumit, kompleks dan bersifat universal, tetap dapat dikuasai anak dalam waktu yang relatif singkat, yaitu dalam waktu antara 3-4 tahun saja

Teori hipotesis nurani menyebutkan bahwa pemerolehan bahasa sangat didukung adanya LAD (Language Acquisition Device). Chomsky dan Miller (1957) menyebutkan bahwa LAD dimiliki anak sejak lahir, sehingga anak-anak dimungkinkan mampu memperoleh B1. Disamping itu LAD membuat anak mampu memperkirakan struktur bahasa. Oleh karena itu, banyak tata bahasa pertama yang tidak perlu dipelajari secara khusus. Struktur dan pola-pola bahasa yang dibawa sejak lahir itu sama dalam semua bahasa, hal inilah yang disebut tata bahasa semesta (universal grammar). Karena semua orang dilengkapi LAD, maka seorang anak 
tidak perlu menghafal dan menirukan pola-pola kalimat agar mampu menguasai bahasa itu. Ia akan mampu mengucapkan suatu kalimat yang belum pernah didengar sebelumnya dengan menerapkan kaidah-kaidah tata bahasa yang tidak sadar diketahui melalui LAD, dan yang dicamkan dalam hati (internalize).

Hipotesis nurani dibagi menjadi dua macam, yaitu hipotesis nurani mekanisme dan hipotesis nurani bahasa. Hipotesis nurani mekanisme menyatakan bahwa proses pemerolehan bahasa manusia ditentukan oleh perkembangan kognitif umum dan mekanisme nurani umum yang berinteraksi dengan pengalaman. Sedangkan hipotesis nurani bahasa merupakan satu asumsi yang menyatakan bahwa sebagian atau keseluruhan bagian dari bahasa tidak diperoleh maupun dipelajari, akan tetapi ditentukan oleh fitur-fitur nurani yang khusus dari organisme manusia. Saat ini, hipotesis nurani bahasa lebih dikenal dengan nania, yang diusulkan oleh Mc. Neil (1970), hipotesis kesemestaan linguistik kuat atau versi kuat hipotesis nurani. Sedangkan hipotesis nurani mekanisme disebut kesemestaan linguistik lemah atau veri lemah hipotesis nurani.

\section{b. Hipotesis Tabularasa}

Hipotesis tabularasa menyatakan bahwa pada waktu bayi dilahirkan otak bayi masih seperti kertas kosong, nantinya akan diisi dengan pengalaman-pengalaman. Hipotesis ini dikemukakan oleh John Locke, kemudian disebarluaskan oleh tokoh terkemuka aliran behaviorisme dalam psikologi yaitu John Watson (Chaer, 2015 : 173). 
Teori ini menyatakan bahwa semua pengetahuan dalam bahasa manusia yang tampak dalam perilaku berbahasa merupakan hasil dari integrasi beberapa peristiwa linguistik yang dialami maupun yang diamatinya. Sejalan dengan hipotesis ini, teori behaviorisme menyoroti aspek perilaku kebahasaan yang dapat diamati langsung dan hubungan antara rangsangan (stimulus) dan reaksi (response). Perilaku bahasa yang efektif adalah membuat reaksi yang tepat terhadap rangsangan. Teori ini lebih mengarah pada proses menghafal dan menirukan pola-pola kalimat agar mampu menguasai bahasa tersebut. Penerapan kedua teori ini pada metode pengajaran bahasa disebut sebagai audiolingualisme.

Berbicara merupakan satu respon operan yang dilazimkan kepada sesuatu stimulus dari dalam maupun dari luar yang sebenarnya tidak jelas diketahui (Skinner, 1957 dalam Chaer, 2015). Skinner memperkenalkan sekumpulan kategori respon bahasa yang hampir serupa fungsinya dengan ucapan, yaitu mands, tacts, echoics, textuals, dan intra verbal operant. Mands dalam tata bahasa sama dengan kalimat imperatif, yang merupakan satu operan bahasa di bawah pengaruh stimulus yang bersifat menyingkirkan, merampas, atau menghabiskan. Tacts, merupakan benda atau peristiwa nyata yang muncul sebagai akibat adanya stimulus. Misalnya, jika kita melihat sebuah televisi sebagai stimulus, maka kita akan mengeluarkan satu tact "televisi" sebagai respon. Echoics, adalah satu perilaku berbahasa yang dipengaruhi oleh respon orang lain sebagai stimulusnya, kemudian kita akan meniru ucapan itu. Misalnya ada seseorang yang mengucapkan kata "televisi", maka stimulus tersebut membuat kita mengucapkan kata " televisi” sebagai sebuah respon. 
Textuals, merupakan perilaku berbahasa yang diatur oleh stimulus tertulis sedemikian rupa sehingga bentuk perilaku itu memiliki korelasi dengan bahasa yang tertulis itu. Adapun yang dimaksud sebagai korelasi yaitu hubungan sistemik antara sistem penulisan atau ejaan suatu bahasa dengan respon ucapan apabila membacanya secara langsung. Sebagai contoh, ketika kita melihat tulisan "televisi" sebagai stimulus, maka sebagai respons kita mengucapkan kata tersebut. Intraverbal operant, yaitu operan berbahasa yang diatur oleh perilaku berbahasa terdahulu yang dilakukan atau dialami oleh penutur. Misalnya, jika ada sebuah kata yang dituliskan sebagai stimulus, maka kata lain yang ada hubungannya dengan kata tersebut akan diucapkan sebagai respon. Jika ada seseorang mengucapkan kata "televisi" sebagai stimulus, maka akan membangkitkan kata "remote" sebagai bentuk responnya.

\section{c.Hipotesis Kesemestaan Kognitif}

Teori ini diperkenalkan oleh Piaget dan telah digunakan sebagai dasar untuk menjelaskan proses-proses pemerolehan bahasa anak. Menurut teori ini, bahasa diperoleh berdasarkan struktur-stuktur kognitif deriamotor (Chaer, 2015). Beberapa struktur ini diperoleh anak-anak melalui interaksi terhadap benda atau orang-orang yang ada di sekitarnya. Adapun urutan pemerolehan bahasa ini secara garis besar dijelaskan sebagai berikut:

1. Anak usia $0-1,5$ tahun.

Pada usia 0- 1,5 tahun, anak-anak mengembangkan pola-pola aksi dengan cara bereaksi terhadap alam sekitarnya. Pola-pola ini kemudian diatur menjadi 
struktur-struktur akal atau mental. Berdasarkan struktur akal ini, seorang anak akan mulai membangun satu dunia benda-benda yang kekal atau disebut sebagai kekekalan benda. Anak-anak akan mulai sadar bahwa meskipun benda-benda yang pernah ia amati ataupun disentuh hilang dari pandangannya, akan tetapi tidak berarti banda tersebut sudah tidak ada lagi. Benda tersebut bisa dicari dengan struktur aksi tertentu, atau bisa dilihat lagi di tempat lain.

\section{Usia 2-7 tahun}

Pada usia 2-7 tahun, anak-anak memasuki tahap representasi kecerdasan. Anak-anak mampu membentuk representasi simbolik benda-benda seperti permainan simbolik, peniruan, gambar, dan lain sebagainya. Setelah melalui tahap representasi kecerdasan dan representasi simbolik, maka bahasa anak semakin berkembang.

\section{PERKEMBANGAN BAHASA PADA ANAK}

Setiap anak yang normal pertumbuhan pikirannya akan belajar bahasa pertamanya atau bahasa ibu pada masa tahun-tahun pertama dalam hidupnya, proses ini terjadi hingga kira-kira umur lima tahun. Perkembangan bahasa pada anak terjadi dan dipengaruhi oleh beberapa faktor, sebagaimana disebutkan oleh para ahli yang menjelaskan tentang pemerolehan bahasa pertama. Beberapa teori yang menyatakan tentang perkembangan bahasa pada anak adalah teori nativisme yang berpendapat bahwa penguasaan bahasa pada anak bersifat alamiah, behaviorisme, yang menyatakn bahwa penguasaan bahasa pada anak bersifat suapan 
(nurture), dan kognitivisme yang berpendapat bahwa penguasaan bahasa berasal dari pematangan kognitif.

a. Teori Nativisme

Teori ini dipelopori oleh Noam Chomsky pada awal tahun 1960-an. Pandangan nativisme terhadap pemerolehan bahasa pertama yaitu selama proses pemerolehan bahasa pertama, anak-anak sedikit demi sedikit membuka kemampuan lingualnya yang secara genetis telah diprogramkan (Chaer, 2015). Menurut teori nativisme lingkungan dianggap tidak mempunyai pengaruh dalam proses pemerolehan bahasa, karena bahasa merupakan pemberian biologis sebagaimana yang disebut dalam teori hipotesis nurani. Teori nativisme juga menyatakan bahwa bahasa itu terlalu kompleks dan rumit sehingga mustahil dapat dipelajari dalam waktu singkat melalui metode peniruan.

Nativisme juga percaya bahwa setiap manusia yang lahir sudah dibekali dengan suatu alat untuk memperoleh bahasa yaitu $L A D$. Alat ini dianggap sebagai bagian fisiologis dari otak yang khusus digunakan untuk memproses bahasa dan tidak ada kaitannya dengan kemampuan kognitif lainnya.

\section{b. Teori Behaviorisme}

Teori behaviorisme menyatakan bahwa pemerolehan bahasa pertama dikendalikan oleh rangsangan yang diberikan oleh anak melalui lingkungan (Chaer, 2015). Anak dianggap sebagai penerima pasif dari lingkungan, sehingga dia tidak memiliki peranan aktif dalam proses perkembangan perilaku verbalnya. Pandangan behaviorisme 
menyatakan bahwa proses perkembangan bahasa pada anak ditentukan oleh lamanya latihan yang diberikan oleh lingkungannya. Dalam hal ini, stimulus dari lingkungan tertentu akan memperkuat kemampuan berbahasa pada anak. Kaum behavioris tidak mengakui pandangan bahwa anak menguasai kaidah bahasa dan memiliki kemampuan untuk mengabstrakkan ciri penting dari bahasa di lingkungannya. Stimulus dari lingkungan tertentu akan memperkuat kemampuan berbahasa pada anak.

\section{c. Teori Kognitivisme}

Teori ini dipelopori oleh Jean Piaget yang mengatakan bahwa bahasa merupakan salah satu di antara beberapa kemampuan yang berasal dari kematangan kognitif. Dengan kata lain, perkembangan bahasa itu ditentukan oleh urutanurutan perkembangan kognitif dan bukanlah suatu ciri alamiah yang terpisah, melainkan salah satu diantara beberapa kemampuan yang berasal dari kematangan kognitif. Bahasa terstruktur karena adanya nalar, maka perkembangan bahasa juga harus didasarkan pada perubahan yang lebih mendasar pada kognisi. Jadi, urutanurutan perkembangan kognitif menentukan urutan perkembangan bahasa (Chaer, 2003:223). Hal ini tentu saja berbeda dengan pendapat Chomsky yang menyatakan bahwa mekanisme umum dari perkembangan kognitif tidak dapat menjelaskan struktur bahasa yang kompleks, abstrak, dan khas. Begitu juga dengan lingkungan berbahasa. Bahasa harus diperoleh secara alamiah. 
Sejalan dengan beberapa teori di atas, Poerwo (dalam Chaer, 2015) menjelaskan bahwa proses perkembangan bahasa pada anak dibagi menjadi dua tahapan, yaitu (1) tahap perkembangan artikulasi, dan (2) tahap perkembangan kata dan kalimat.

1. Tahap perkembangan artikulasi

Tahapan ini akan dilalui oleh bayi yang berusia nol hingga usia kurang lebih 14 bulan. Tahap perkembangan artikulasi ini dibagi menjadi beberapa rangkaian, yaitu:

\section{a. Bunyi resonansi}

Bunyi yang dihasilkan oleh seorang bayi yang terjadi di dalam rongga mulut tidak terlepas dari kegiatan serta perkembangan motorik (Chaer, 2015). Kegiatan ini dilakukan oleh seorang bayi sampai mereka berusia enam bulan, yaitu sekatu bayi menyusu pada ibunya. Dalam kegiatan menyusu ini, si bayi akan menghasilkan gerak ritmis yang disebut sebagai kenyut-telan atau suck-swallow. Pada saat bayi baru lahir, proses kenyutan ini melibatkan gerak rahang ke atas dan ke bawah. Berikutnya, beberapa minggu kemudian bayi akan mengembangkan gerakan kenyutannya ke arah samping. Pertumbuhan yang cepat yang terjadi di dalam rongga mulut, hidung, dan leher pada seorang bayi memungkinkan adanya peluang dalam menghasilkan berbagai macam bunyi. Bunyi yang paling umum yang dihasilkan oleh bayi adalah bunyi tangisan karena merasakan atau meminta sesuatu, misalnya merasa lapar, atau tidak enak badan. Menjelang akhir bulan pertama, bunyi tangisan bayi 
mulai bisa dibedakan. Tangisan yang mengindikasikan bayi saat merasa lapar, atau merasa tidak nyaman akan mulai bisa dibedakan. Seorang ibu biasanya akan memperhatikan pola tangisan seorang bayi.

b. Bunyi dekutan

Pada tahap ini bayi sudah mulai menghasilkan suara tawa dan juga berdekut (cooing). Seorang anak melalui tahapan ini saat ia berusia antara dua sampai tiga bulan. Bunyi yang dihasilkan saat berdekut adalah bunyi konsonan belakang dan tengah vokal belakang, tapi tanpa resonansi penuh. Bunyi konsonan yang dihasilkan mirip seperti bunyi [s] dan bunyi hambat velar yang mirip dengan bunyi $[\mathrm{k}]$ dan $[\mathrm{g}]$. Bunyi dekutan sering kali disertai dengan suara tawa dan terjadi saat bayi berinteraksi dengan orang lain.

c. Bunyi berleter

Bunyi ini biasanya dihasilkan oleh seorang bayi saat ia berusia antara empat sampai enam bulan. Pada tahap ini si bayi sudah mampu membuat bunyi vokal yang mirip bunyi [a]. Kemampuan bayi untuk mengatupkan bibir memungkinkan dapat menghasilkan bunyi labial. Bunyi yang dihasilkan itu mirip bunyi frikatif, tetapi lebih bergetar. Masa ini lazim disebut sebagai masa berleter atau dikenal dengan istilah babling. Anak akan mengucapkan sejumlah bunyi ujaran tanpa makna atau beberapa penggal kata saja karena kebetulan (Indah, 2008). Senada dengan hal tersebut, Dardjowidjojo (2000) menjelaskan bahwa seorang anak pada usia sekitar 6 bulan sudah mulai 
mengeluarkan bunyi-bunyi konsonan atau vokal. Seorang anak dalam masa babbling cenderung mengkombinasikan antara bunyi konsonan yang diikuti dengan bunyi vokal.

\section{d. Bunyi berleter ulang}

Tahap ini dilaui oleh seorang anak saat berusia enam sampai sepuluh bulan. Menjelang usia enam bulan, si anak mampu menggerakkan bibir ke depan dan menariknya ke dalam tanpa menggerakkan rahang. Kemudian, dua bulan berikutnya anak mampu mengatupkan bibirnya rapat-rapat selama mengunyah dan menelan makanan yang agak cair. Lalu, saat si anak berusia delapan bulan, pola penjuluran dan penarikan lidahnya secara berangsur berubah menjadi gerakan ke samping, dan dapat dinaikkan tanpa tergantung pada gerakan rahang (Chaer, 2015). Konsonan yang mula-mula diucapkan oleh bayi adalah bunyi labial $[\mathrm{p}]$ dan [b], bunyi letup alveolar [t] dan [d], serta bunyi nasal dan bunyi [j]. Bunyi yang dihasilkan umumnya bunyi yang suku katanya merupakan rangkaian konsonan dan vokal, misalnya ba-ba-ba atau ma-ma-ma. Bunyi berleter ini biasanya dihasilkan oleh seorang bayi saat ia sendirian

e. Bunyi vokabel

Bunyi vokabel merupakan bunyi yang hampir menyerupai kata, akan tetapi tidak memiliki arti, dan bukan merupakan tiruan dari orang dewasa. Bunyi vokabel ini dihasilkan oleh seorang anak yang berusia antara 11 hingga 14 bulan. Menjelang usia satu tahun, anak sudah mampu mengenal berbagai macam bunyi, 
dan tidak lagi mengulang gabungan konsonan dan vokal, akan tetapi sudah membuat gabungan yang bervariasi. Intonasi yang dihasilkanpun menyerupai bicaranya orang dewasa, rentetan bunyi mirip seperti kalimat berita atau kalimat tanya akan tetapi isinya tidak bisa dipahami. Anak melakukan bunyi vokabel saat ia sedang sendiri.

\section{Tahap perkembangan kata dan kalimat}

Penguasaan kata dan kalimat dilalui oleh seorang anak secara bertahap. Mulai tahap kata pertama, kalimat satu kata, kaimat dua kata, hangga menghasilkan sebuah kalimat.

a. Kata pertama

De Villerr, (1979) (dalam Chaer, 2015) menjelaskan bahwa pengucapan kata pertama oleh seorang anak sangat ditentukan oleh penguasaan artikulasi, serta kemampuan mengaitkan kata dengan benda yang menjadi rujukannya. Pengaitan subuah kata dengan benda tertentu akan memudahkan seorang anak dalam mengucapkan kata tersebut.

b. Kalimat satu kata

Kata yang dihasilkan oleh anak pertama kali akan diikuti oleh kata kedua, ketiga, dan seterusnya hingga menghasilkan kalimat yang bermakna. Kata yang pertama kali muncul merupakan ujaran yang sering diucapkan oleh orang dewasa dan yang sering didengarnya, atau kata yang sudah akrab seperti mainan, orang, 
binatang piaraan, makanan atau pakaian. Kalimat satu kata ini disebut juga dengan holofrastis. Para pakar berpendapat bahwa kalimat satu kata yang dihasilkan oleh seorang anak dapat dianggap bukan sebagai kalimat, karena maknanya sukar diprediksi (Chaer, 2015). Pada usia satu tahun anak mulai menggunakan serangkaian bunyi berulang-ulang untuk makna yang sama. Misalnya Mam (untuk mengatakan saya mau makan), $M a$ (untuk meminta supaya mamanya ada di sini) (Indah, 2008). Kata-kata dalam tahapan ini memiliki tiga fungsi, yaitu : (1) menghubungkan antara kata-kata dengan perilaku anak itu sendiri, (2) untuk mengungkapkan suatu perasaan, dan (3) untuk memberi nama suatu benda. Kata-kata dalam tahapan ini terdiri dari konsonan yang mudah dilafalkan seperti ( $m, p, j$, dan $k)$, dan vokal seperti (a,u, dan o).

c. Kalimat dua kata

Kalimat yang dihasilkan oleh anak pada tahap ini terdiri dari dua buah kata. Tahap ini berlangsung sewaktu anak berusia menjelang 18 bulan. Tahap ini memasuki tahap pertama kali mengucapkan dua kata dalam rangkaian yang cepat. Komunikasi yang ingin ia sampaikan adalah bertanya dan meminta. Dalam pikitan anak konsep subyek + predikat terdiri dari kata benda + kata benda, misalnya "makan anggur", yang berarti ia ingin makan anggur, atau menghubungkan kata 
sifat, seperti " kotor baju” yang berarti baju ini kotor, dan sebagainya.

d. Kalimat lebih lanjut

Penguasaan kalimat lebih lanjut ini dilalui oleh seorang anak setelah penguasaan dua katanya tercapai. Menjelang usia dua tahun, rata-rata anak sudah mampu menyusun kalimat yang terdiri dari empat kata. Pada masa ini perkembangan bahasa anak berkembang sangat pesat, terutama jika seorang ibu sering menggunakan berbagai teknik untuk mengajak seorang anak untuk bercakapcakap.

\section{E. RANGKUMAN}

a. Bahasa merupakan suatu sistem lambang bunyi yang bersifat arbitrer dan digunakan oleh sekelompok masyarakat untuk berinteraksi dan mengidentifikasikan diri.

b. Bahasa memiliki beberapa karakteristik diantaranya: (a) Sistematis, (b) Arbitrer, (c) fleksibel, (d) beragam, dan (e) kompleks.

c. Bahasa memiliki ciri, diantaranya: (a) bahasa merupakan sebuah sistem, (b) bahasa berwujud lambang, (c) bahasa itu berupa bunyi, (d) bahasa bersifat arbitrer, (e) bahasa itu bermakna, (f) bahasa bersifat konvensional, (g) bahasa bersifat unik, (h) bahasa bersifat universal, (i) bahasa bersifat produktif, (j) bahasa itu bervariasi, (k) bahasa bersifat dinamis, (l) bahasa berfungsi sebagai alat interaksi 
sosial, dan (m) bahasa merupakan identitas penuturnya

d. Pemerolehan bahasa pertama pada dasarnya terjadi melalui dua proses, yaitu proses kompetensi dan performansi

e. Proses kompetensi merupakan penguasaan tata bahasa yang berlangsung secara tidak sadar. Proses kompetensi ini menjadi syarat untuk terjadinya proses performansi.

f. Proses performansi terdiri dari dua buah proses, yaitu proses pemahaman dan juga penerbitan atau proses menghasilkan kalimat. Proses pemahaman melibatkan kemampuan mengamati dan mempersepsi kalimat yang didengar. Sedangkan proses penerbitan melibatkan kemampuan mengeluarkan kalimatkalimat sendiri. Apabila kedua proses ini telah dikuasai oleh anak-anak maka akan menjadi kemampuan linguistik anak tersebut.

g. Beberapa teori yang menjelaskan tentang pemerolehan bahasa pertama diataranya: Teori Hipotesis nurani (Innateness hypotesis), Teori Hipotesis Tabularasa, dan Teori Hipotesis Kesemestaan Kognitif

h. Beberapa teori yang menyatakan tentang perkembangan bahasa pada anak adalah (1) Teori nativisme yang berpendapat bahwa penguasaan bahasa pada anak bersifat alamiah, (2) behaviorisme, yang menyatakan bahwa penguasaan bahasa pada anak bersifat suapan (nurture), dan (3) kognitivisme 
yang berpendapat bahwa penguasaan bahasa berasal dari pematangan kognitif.

i. Proses perkembangan bahasa pada anak dibagi menjadi dua tahapan, yaitu (1) tahap perkembangan artikulasi, dan (2) tahap perkembangan kata dan kalimat.

\section{F. SOAL EVALUASI}

1. Jelaskan apa yang dimaksud dengan bahasa menurut beberapa ahli!

2. Berikan penjelasan mengenai karakteristik bahasa!

3. Diskusikan dengan temanmu mengenai proses kompetensi dan performansi!

4. Diskusikan dengan teman sekelasmu mengenai perkembangan bahasa anak mulai dari tahap pra linguistik sampai tahap linguistik (usia 5 tahun).

5. Menurut paham behaviorisme, proses perkembangan bahasa ditentukan oleh lamanya latihan yang diberikan oleh lingkungannya. Jelaskan maksud dari pernyataan tersebut!

6. Diskusikan dengan teman sekelompokmu mengenai konsep keberadaan LAD dan bagaimana cara kerjanya?

7. Jelaskan mengenai keterkaitan antara perkembangan bahasa dengan perkembangan sosial anak!

8. Jelaskan mengenai perbedaan pendapat antara Chomsky dan Piaget mengenai pemerolehan bahasa pada anak!

9. Jelaskan mengenai hubungan antara hipotesis nurani dengan teori perkembangan kognitif! 
10. Berikan pendapatmu mengenai kekuatan dan kelemahan teori behavioristik!

11. Jelaskan mengenai urutan pemerolehan bahasa menurut hipotesis Tabularasa!

12. Jelaskan mengenai urutan pemerolehan bahasa menurut hipotesis kesemestaan kognitif! 


\section{BAB II}

\section{RAGAM BAHASA INDONESIA}

\section{Tujuan Instruksional}

Mampu memahami dan menguasai konsep dasar bahasa Indonesia yang meliputi ragam bahasa baku dan tidak baku, serta penggunaan bahasa baku dan tidaka baku

\section{A. PENGERTIAN RAgAM BAHASA}

Ragam bahasa merupakan variasi bahasa menurut aturan pemakaian, topik pembicaraan, hubungan antara pembicara dengan lawan bicara, serta media pembicaraan (Chaer, 2012). Penggunaan bahasa pada situasi formal digunakan ragam bahasa baku atau bahasa standar, sedangkan dalam situasi nonformal digunakan bahasa tidak baku atau nonstandar. Berdasarkan media atau sarana yang digunakan, ragam bahasa dibedakan menjadi dua jenis yaitu bahasa lisan dan bahasa tulis. Bahasa lisan yaitu bahasa yang dihasilkan oleh alat ucap, sedangkan bahasa tulis yaitu bahasa yang ditulis atau dicetak. Terdapat beberapa perbedaan antara bahasa lisan dan bahasa tulis, diantaranya dari aspek suasana peristiwanya, dan fungsi gramatikalnya. Orang yang menggunakan bahasa lisan akan menyertakan gerak atau isyarat, pandangan, anggukan dan ekspresi lainnya yang tidak mungkin muncul pada bahasa tulis. Selain itu, intonasi, tinggi rendahnya suara, dan irama yang biasanya terjadi pada bahasa lisan juga tidak bisa digambarkan dalam bahasa tulis. Intonasi, ekspresi, serta nada suara yang digunakan dalam ragam bahasa lisan mempengaruhi makna ujaran yang disampaikan. Sedangkan 
dalam bahasa tulis, penggunaan tanda baca sangat mempengaruhi makna kalimat yang dituliskan.

Apabila ditinjau dari aspek gramatikalnya, penggunaan subyek, predikat dan objek sangat penting dalam ragam bahasa tulis, akan tetapi dalam ragam bahasa lisan, unsurunsur tersebut tidak selalu dinyatakan dengan kata-kata, karena penutur dalam bahasa lisan berkomunikasi secara langsung, fungsi tersebut dinyatakan dengan isyarat gerak tubuh. Ragam bahasa lisan umumnya digunakan dalam ceramah, pidato, membaca berita, dan sebagainya, sedangkan ragam bahasa tulis umumnya digunakan dalam penulisan artikel, majalah, karya ilmiah, dan sebagainya.

Terkait dengan penggunaan ragam bahasa baku tulis, penguasaan ejaan, susunan kalimat, tata bahasa dan kosakata (pemilihan kata) sangat diperlukan agar mampu menghasilkan bahasa Indonesia yang baik dan benar. Sedangkan untuk ragam bahasa lisan kita harus mampu menggunakan bahasa Indonesia dengan baik dan sopan.

Apabila ditinjau dari aspek situasi pemakaian bahasa, ragam bahasa dibagi menjadi tiga jenis, yaitu ragam formal, ragam nonformal, dan ragam semiformal. Ragam bahasa formal digunakan dalam situasi resmi dan menggunakan bahasa baku, misalnya digunakan dalam pidato, komunikasi resmi, dan sebagainya. Sedangkan ragam semiformal digunakan dalam situasi semiformal. Penggunaan ragam bahasa semiformal tetap memenuhi kaidah atau aturan berbahasa, akan tetapi terkadang menggunakan bahasa tidak baku tergantung tujuannya, mislanya pembacaan berita. Ragam nonformal digunakan dalam situasi yang tidak resmi 
dan menggunakan bahasa percakapan sehari-hari, misalnya bercakap-cakap dengan teman, dan sebagainya.

\section{B. RAGAM BAHASA BAKU DAN TIDAK BAKU 1. Ragam Bahasa Baku}

Ragam bahasa baku merupakan ragam bahasa yang sesuai dengan kaidah bahasa Indonesia baku serta diakui oleh sebagian besar warga masyarakat pemakainya sebagai bahasa resmi dan menjadi kerangka rujukan norma bahasa. Struktur dan ejaan bahasa baku mengikuti kaidah yang sesuai dengan EYD, serta menggunakan pilihan kata yang tepat sehingga gagasan yang disampaikan dalam kalimat atau ujaran dapat dipahami oleh pembaca atau lawan bicara. Ragam bahasa baku umumnya digunakan dalam beberapa konteks pertama, digunakan dalam komunikasi resmi, misalnya dalam surat resmi, pengumuman yang dikeluarkan oleh instansi resmi, perundang-undangan, dan sebagainya. Kedua, digunakan dalam wacana teknis, misalnya untuk menuliskan laporan resmi, karangan ilmiah, dan sebagainya. Ketiga, digunakan dalam konteks pembicaraan di depan umum, misalnya ceramah, pidato dan sebagainya. Keempat, digunakan saat berbicara dengan orang yang dihormati yang sifatnya formal.

Muslich (1990) menjelaskan bahwa bahasa baku memiliki beberapa ciri, diantaranya:

a. Memiliki sifat kemantapan dinamis, artinya bahasa baku harus memiliki kaidah dan aturan yang tetap dan luwes. Bahasa baku tidak dapat berubah setiap saat.

b. Bersifat kecendekiaan, artinya bahwa bahasa baku dapat mengungkapkan penalaran atau pemikiran yang teratur, logis dan masuk akal. Ragam baku berangkat dari nalar 
bahwa proses berfikir secara ilmiah bersifat semesta dan bukan monopoli bangsa Barat, artinya sifat kecendikiaan dalam bahasa bau bukan berarti pembaratan bahasa.

c. Penyeragaman kaidah, artinya adanya keseragaman aturan atau norma. Akan tetapi bukan berarti penyamaan ragam bahasa.

Selain pendapat Muslich di atas, Suandi, dkk, (2013) menjelaskan bahwa terdapat beberapa ciri bahasa Indonesia baku, yaitu:

a. Dari segi bahasa lisan, bahasa Indonesia baku menggunakan lafal yang baku. Terkait dengan lafal baku, belum ada ketentuan bagaimana pelafalan baku dalam bahasa Indonesia, akan tetapi yang bisa dijadikan acuan yaitu tidak adanya pengaruh pelafalan dari daerah. Misalnya masyarakat Jawa melafalkan kata Blitar dengan lafal sengau, bunyi /b/ pada kata Blitar dilafalkan sebagai mBlitar.

b. Dari segi bahasa tulis, bahasa Indonesia baku sesuai dengan EYD.

c. Tidak terpengaruh oleh unsur bahasa daerah, baik secara leksikal maupun gramatikal. Misalnya : Saya cinta sama dia. (Bahasa tidak baku)

Saya mencintai dia. (Bahasa baku)

d. Fungsi gramatikal (subjek, predikat, dan sebagainya) digunakan secara eksplisit dan konsisten. Misalnya: Kemarin saya ke Blitar. (Bahasa tidak baku)

Kemarin saya pergi ke Blitar. (Bahasa baku)

e. Konjungsi digunakan secara eksplisit dan konsisten. 
Misalnya: Ayah sudah tahu kamu yang menyapu halaman itu. (Bahasa tidak baku)

Ayah sudah tahu bahwa kamu yang menyapu halaman itu. (Bahasa baku)

f. Awalan meN- dan ber- digunakan secara konsisten.

Misalnya: Kakak kerja di perusahaan terkenal. (Bahasa tidak baku)

Kakak bekerja di perusahaan terkenal. (Bahasa baku)

\section{Ragam Bahasa tidak Baku}

Ragam bahasa tidak baku bisa diartikan sebagai bahasa yang tidak sesuai dengan kaidah baku bahasa Indonesia baik dari segi struktur, ejaan, pelafalan, mupun penulisan. Ragam bahasa tidak baku umumnya digunakan dalam percakapan sehari-hari yang sifatnya tidak formal, misalnya percakapan dengan teman, percakapan yang terjadi di pasar, tulisan di buku harian, dan sebagainya. Beberapa contoh kata tidak baku yaitu gue, nyokap, ketemu,lain kesempatan, dan sebagainya.

\section{FUNGSI BAHASA BAKU}

Sebelum membahas penggunaan bahasa baku, terlebih dahulu akan dibahas mengenai fungsi bahasa secara umum. Secara umum, bahasa berfungsi sebagai alat interaksi sosial dalam artian alat untuk menyampaikan pikiran, gagasan, konsep, dan juga perasaan (Chaer, 2015). Sedangkan menurut Kinneavy (dalam Chaer, 2015) bahasa memiliki beberapa fungsi dasar, diantaranya fungsi ekspresi, fungsi informasi, 
fungsi eksplorasi, fungsi persuasi, dan fungsi entertainment. Fungsi informasi artinya bahasa digunakan untuk menyampaikan pesan atau amanat kepada orang lain. Fungsi eksplorasi artinya bahasa digunakan untuk menjelaskan suatu hal, atau keadaan tertentu. Fungsi persuasi yaitu bahasa digunakan untuk mempengaruhi dan mengajak orang lain untuk melakukan ataupun tidak melakukan sesuatu secara baik-baik. Fungsi entertainmen yaitu bahasa digunakan untuk menghibur, menyenangkan, atau memuaskan perasaan batin.

Penggunaan ragam bahasa cukup berpengaruh terhadap kehidupan masyarakat. Penggunaan ragam bahasa perlu disesuaikan dengan konteks dan latar belakang pengguna bahasa. Muslich (1990) menjelaskan ada tiga fungsi bahasa baku, yaitu:

1. Sebagai pelambang (simbolis)

Bahasa baku berfungsi sebagai pelambang yaitu pemersatu dan pemberi kekhasan Bahasa Indonesia. Dengan adanya bahasa Indonesia baku mampu mempersatukan segala penutur dari bermacam-macam dialek, sehingga kepribadian nasional akan semakin kuat. Bahasa Indonesia juga memiliki kekhasan dibandingkan bahasa-bahasa lainnya. Bahkan, Bahasa Indonesia berbeda dengan bahasa-bahasa Melayu di Singapura, Malaysia, Brunei, bahkan memiliki perbedaan dengan Bahasa Melayu Riau yang dulunya menjadi induknya. Dengan demikian, penggunan ragam bahasa baku dapat dijadikan modal untuk mewujudkan integrasi nasional dan harmoni sosial.

2. Fungsi pembawa kewibawaan 
Bahasa Indonesia baku baik dari segi norma dan kaidahnya menjadi tolok ukur benar tidaknya pemakaian bahasa Indonesia. Oleh karena itu, fungsi pembawa kewibawaan menuntut orang agar berbahasa dengan baik dan benar. Bahkan, dapat disaksikan bahwa adanya penghormatan kepada pemakai bahasa yang baik dan benar. Bahasa Indonesia yang baik mengacu pada pemakaian bahasa Indonesia yang sesuai dengan situasi kebahasaan yang ada, sedangkan bahasa Indonesia yang benar mengacu pada pemakaian bahasa Indonesia yang sesuai dengan kaidah bahasa.

\section{Fungsi yang bersifat obyektif}

Bahasa Indonesia baku menjadi kerangka acuan bagi fungsi estetika bahasa. Dalam hal ini, fungsi tersebut tidak hanya terbatas pada bidang sastra, akan tetapi mencakup bidang lainnya, misalnya bidang permainan kata, iklan, serta berita.

\section{RANGKUMAN}

a. Ragam bahasa merupakan variasi bahasa menurut aturan pemakaian, topik pembicaraan, hubungan antara pembicara dengan lawan bicara, serta media pembicaraan.

b. Ditinjau dari aspek situasi pemakaian bahasa, ragam bahasa dibagi menjadi tiga jenis, yaitu ragam formal, ragam nonformal, dan ragam semiformal.

c. Ragam bahasa formal digunakan dalam situasi resmi dan menggunakan bahasa baku, misalnya digunakan dalam pidato, komunikasi resmi, dan sebagainya.

d. Ragam semiformal digunakan dalam situasi semiformal. 
e. Ragam nonformal digunakan dalam situasi yang tidak resmi dan menggunakan bahasa percakapan sehari-hari, misalnya bercakap-cakap dengan teman, dan sebagainya.

f. Ragam bahasa baku merupakan ragam bahasa yang sesuai dengan kaidah bahasa Indonesia baku serta diakui oleh sebagian besar warga masyarakat pemakainya sebagai bahasa resmi dan menjadi kerangka rujukan norma bahasa.

g. Ragam bahasa baku biasa dipakai dalam pertemuanpertemuan yang bersifat formal, dalam tulisan-tulisan ilmiah (makalah, skripsi, tesis, disertasi), percakapan dengan pihak yang berstatus akademis yang lebih tinggi, dan sebagainya.

h. Bahasa baku memiliki beberapa ciri, diantaranya memiliki sifat kemantapan dinamis, bersifat kecendekiaan, dan penyeragaman kaidah, artinya adanya keseragaman aturan atau norma.

i. Bahasa Indonesia baku memiliki beberapa ciri yaitu: menggunakan lafal yang baku, sesuai dengan EYD, tidak terpengaruh oleh unsur bahasa daerah, baik secara leksikal maupun gramatikal, fungsi gramatikal (subjek, predikat, dan sebagainya) digunakan secara eksplisit dan konsisten, konjungsi digunakan secara eksplisit dan konsisten, dan awalan meN- dan ber- digunakan secara konsisten.

j. Bahasa baku memiliki beberapa fungsi yaitu:sebagai pelambang (simbolis), pembawa kewibawaan, bersifat obyektif.

k. Ragam bahasa tidak baku bisa diartikan sebagai bahasa yang tidak sesuai dengan kaidah baku bahasa Indonesia baik dari segi struktur, ejaan, pelafalan, mupun penulisan. 
1. Bahasa nonbaku berfungsi untuk mengakrabkan diri dan menciptakan kenyamanan serta kelancaran saat berkomunikasi (berbahasa).

\section{E.SOAL EVALUASI}

1. Jelaskan apa yang dimaksud dengan ragam atau variasi bahasa!

2. Diskusikan dengan teman sekelasmu mengenai penggunaan ragam bahasa baku dan tidak baku!

3. Berikan masing-masing contoh kalimat baku dan tidak baku!

4. Jelaskan fungsi dari bahasa baku dan tidak baku!

5. Berikan penjelasan mengenai beberapa faktor yang menyebabkan adanya ragam bahasa! 


\section{BAB III \\ MORFOLOGI BAHASA INDONESIA}

\section{Tujuan Instruksional}

Mampu memahami dan menganalisis morfologi bahasa Indonesia: morfem, alomorf, dan kata dasar

\section{A. PENGERTIAN MORFOLOGI}

Secara etimologi, kata morfologi berasal dari kata morf yang berarti bentuk, dan kata logi yang berarti ilmu. Kata morphologie berasal dari bahasa Yunani morphe yang digabungkan dengan logos. Morfologi merupakan cabang linguistik yang mengidentifikasi satuan-satuan dasar bahasa sebagai satuan gramatikal (Venhaar, 2012). Morfologi mempelajari seluk-beluk bentuk kata dan pengaruh perubahan bentuk kata terhadap golongan dan arti kata. Atau dengan kata lain dapat dikatakan bahwa morfologi mempelajari seluk-beluk bentuk kata serta fungsi perubahan-perubahan bentuk kata itu, baik fungsi gramatik maupun fungsi semantik. Di dalam hierarki linguistik, kajian morfologi berada diantara kajian fonologi dan sintaksis. Keterkaitan morfologi dengan fonologi tampak jelas dengan adanya kajian yang disebut sebagai morfonologi atau morfofonemik, yaitu ilmu yang mengkaji terjadinya perubahan fonem akibat adanya proses morfologi. Sedangkan kaitan antara morfologi dengan sintaksis tampak dengan adanya kajian yang disebut serbagai morfosintaksis. Morfologi mengkaji berbagai hal yang berkaitan dengan satuan-satuan morfologi, proses morfologi serta alat-alat dalam proses morfologi. Objek satuan morfologi mencakup morfem serta kata. Sedangkan 
proses morfologi melibatkan komponen dasar (bentuk dasar), alat pembentuk (afiks, duplikasi, komposisi,akronimisasi, serta konversi), dan maksa gramatikal (Chaer, 2008).

\section{B. MORFEM}

Morfem adalah satuan bahasa atau gramatikal terkecil yang memiliki makna (Chaer, 2012). Sedangkan menurut Ramlan (1983) morfem ialah satuan gramatik yang paling kecil yang tidak mempunyai satuan lain selain unsurnya. Morfem dapat berupa akar (dasar) dan dapat pula berupa afiks. Sebagai satuan gramatikal terkecil, morfem tidak dapat dipecah menjadi bagian-bagian yang lebih kecil, karena makna yang terkandung akan hilang. Dengan kata terkecil berarti satuan itu tidak dapat dianalisis menjadi lebih kecil lagi tanpa merusak maknanya. Misalnya kata mencuci bisa dianalisis menjadi dua bentuk $\{$ me- $\}$ dan \{cuci\}. Bentuk \{me\} merupakan sebuah morfem, yaitu morfem afiks yang secara gramatikal memiliki makna, sedangkan bentuk \{cuci\} juga sebuah morfem, yaitu morfem dasar yang secara leksikal memiliki makna. Jika kata beli dipenggal menjadi be- dan limaka penggalan kata tersebut tidak memiliki makna, kedua penggalan kata tersebut bukan merupakan morfem. Dalam konversi linguistik sebuah bentuk kata dinyatakan sebagai morfem ditulis dalam kurung kurawal atau \{ \}. Morfem dalam setiap bahasa dapat diklasifikasikan berdasarkan beberapa kriteria, antara lain berdasarkan kebebasannya, keutuhanya, maknanya dan sebagainya. 


\section{IDENTIFIKASI MORFEM}

Untuk mengidentifikasi sebuah bentuk termasuk morfem atau bukan maka bisa didasarkan pada bentuk dan makna itu. Berikut merupakan pedoman yang bisa dijadikan sebagai acuan untuk menentukan sebuah morfem atau bukan.

1. Dua bentuk yang sama atau lebih jika memiliki makna yang sama merupakan sebuah morfem. Contoh:

- Bulan depan Roni akan pergi ke Semarang.

- Selama empat bulan pria itu ditinggalkan istrinya.

- Bulan April lamanya 30 hari.

2. Dua bentuk yang sama atau lebih jika memiliki makna yang berbeda merupakan morfem yang berbeda. Contoh

- Robi membawa setangkai bunga melati untuk Ibunya.

- Koperasi simpan pinjam itu memberi bunga 3 persen per tahun.

3. Dua buah bentuk yang berbeda, tapi memiliki makna yang sama, merupakan dua morfem yang berbeda. Contoh:

- Ibu pergi ke Solo

- Mama membeli sepatu baru.

4. Bentuk-bentuk yang mirip atau sedikit berbeda tetapi memiliki makna yang sama merupakan sebuah morfem yang sama, asalkan perbedaan bentuk tersebut bisa dapat dijelaskan secara fonologis. Misalnya bentuk me-, men-. Contoh:

- melihat

- mendengar

5. Bentuk yang hanya muncul dengan pasangan satu satunya merupakan sebuah morfem. Misalnya bentuk 
bugar pada bentukan kata segar bugar, dan bentuk kuyup pada bentukan kata basah kuyup.

6. Bentuk yang muncul berulang-ulang pada satuan yang lebih besar apabila memiliki makna yang sama merupakan morfem yang sama. Contoh:

- membaca

- pembaca

- bacaan

7. Bentuk yang muncul berulang-ulang pada satuan bahasa yang yang lebih besar (kausa, kalimat) apabila maknanya berbeda secara polisemi merupakan morfem yang sama.

Contoh:

- Pak Hari menjadi kepala staf di perusahaan itu.

- Setiap kepala mendapat bantuan satu juta rupiah.

\section{JENIS MORFEM}

Morfem dalam setiap bahasa bisa dibedakan berdasarkan beberapa kriteria, diantaranya berdasarkan kebebasannya, keutuhannya, maknanya, dan sebagainya. Menurut kebebasannya, morfem dapat dibedakan atas dua macam, yaitu, (a) morfem bebas, dan (b) morfem terikat (Chaer, 2008).

a) Morfem bebas, yaitu morfem yang dapat berdiri sendiri dari segi makna tanpa harus dihubungkan dengan morfem yang lain. Semua kata dasar merupakan morfem bebas, misalnya: \{pulang\}, \{beli\}, \{bawa $\}$ dan sebagainya. Contoh-contoh tersebut dikatakan morfem karena merupakan bentuk terkecil yang dapat berdiri sendiri dan mempunyai arti. Apabila bentuk itu kita pecah lagi, sehingga 
menjadi pu-lang, be-li, dan ba - wa, maka bentuk-bentuk tersebut tidak mempunyai arti.

b) Morfem terikat. Morfem terikat merupakan morfem yang tidak dapat berdiri sendiri dari segi makna. Morfem terikat harus bergabung dengan morfem lain agar dapat digunakan dalam pertuturan. Morfem terikat akan memiliki makna setelah morfem itu dihubungkan dengan morfem yang lain. Dalam hal ini, semua afiks (awalan, sisipan, akhiran, serta kombinasi awalan dan akhiran) dalam bahasa Indonesia termasuk morfem terikat. Prefiks (awalan), misanya: me-, ber-, ter-, di-, ke-, pe-, per-, se. Infiks ( sisipan), misalnya : -em, -el, er-. Sufiks (akhiran), misalnya -an, -i, -kan, -nya, man, -wati, -wan, -nda. Sedangkan konfiks (gabungan) misalnya: ke+an, pe+an, per+an, me+kan, di+kan, me+per+kan, di+per+kan, me+per+i, di+per+i, ber+kan, ber+an. Selain itu unsur-unsur seperti partikel -lah, -kah, dan bentuk lain yang tidak dapat berdiri sendiri, juga tergolong sebagai morfem terikat .

Menurut keutuhannya, morfem dibedakan menjadi dua jenis, yaitu morfem utuh dan morfem terbagi. Morfem utuh secara fisik merupakan satu kesatuan yang utuh. Yang termasuk morfem utuh yaitu semua morfem dasar, baik bebas maupun terikat, serta prefiks, infiks, dan sufiks. Yang dimaksud dengan morfem terbagi yaitu morfem yang disisipi oleh morfem lain atau bisa dikatakan bentuk fisiknya telah terbagi. Yang termasuk morfem terbagi yaitu semua konfiks (pe-an, ke-an, dan per-an). Contoh morfem terbagi yaitu kata perbuatan, terdiri atas satu morfem utuh yaitu \{buat\} serta satu morfem terbagi yaitu $\{$ per-/-an $\}$. 
Berdasarkan jenis fonem yang membentuknya, morfem dibagi menjadi dua jenis yakni, morfem segmental dan morfem suprasegmental. Morfem segmental merupakan morfem yang dibentuk oleh fonem-fonem segmental seperti morfem \{lihat\}, \{lah\}, \{sikat\}, dan \{ber\}. Jadi semua morfem yang berwujud bunyi adalah morfem segmental. Sedangkan morfem suprasegmental adalah morfem yang dibentuk oleh unsur-unsur suprasegmental seperti tekanan, nada, durasi, dan sebagainya.

Berdasarkan ciri semantiknya, morfem dibedakan menjadi dua jenis, yaitu morfem bermakna leksikal dan morfem tak bermakna leksikal. Morfem dikatakan bermakna leksikal karena secara inheren morfem tersebut memiliki makna, misalnya $\{$ makan\}, \{tidur\}, dan sebagainya. Semua morfem dasar bebas termasuk morfem yang bermakna leksikal. Morfem bermakna leksikal ini bisa langsung menjadi unsur dalam pertuturan sedangkan morfem tak bermakna leksikan tidak dapat menjadi unsur dalam pertuturan. Contoh morfem tak bermakna leksikal adalah afiks $\{$ ber- $\},\{$ ke- $\}$, dan $\{$ ter $\}$.

\section{E. MORFEM DASAR, BENTUK DASAR, PANGKAL, AKAR, DAN LEKSEM}

Morfem dasar, bentuk dasar (base), pangkal (stem), akar (root) dan leksem merupakan beberapa istilah yang sering digunakan dalam kajian morfologi. Akan tetapi, seringkali penggunaannya kurang cermat, atau malah berbeda (Chaer, 2008). Morfem dasar merupakan istilah yang yang biasanya dipakai sebagai dikotomi dengan morfem afiks. Sebuah morfem dasar dapat menjadi bentuk dasar dalam suatu proses morfologi, artinya dapat diberi afiks tertentu dalam proses 
afiksasi, dapat diulang dalam proses reduplikasi, atau dapat digabung dengan morfem lainnya dalam proses komposisi atau kemajemukan.

Bentuk dasar (base) merupakan bentuk yang langsung menjadi dasar dalam proses morfologi, yang bisa berwujud morfem tunggal atau dalam bentuk polimorfemis (gabungan morfem), misalnya pada kata berlari terdiri dari morfem \{ber-\} dan \{lari\}, maka morfem \{lari\} menjadi bentuk dasar dari kata berlari, yang kebetulan juga berupa morfem dasar. Contoh lain pada bentuk reduplikasi pada kata buku-buku bentuk dasarnya merupakan buku, reduplikasi kemerahmerahan bentuk dasarnya adalah kemerahan.

Pangkal atau stem digunakan untuk menyebut bentuk dasar dalam proses infleksi, atau proses pembubuhan afiks inflektif. (Chaer, 2008). Dalam bahasa Indonesia proses pembentukan kata inflektif hanya terjadi pada proses pembentukan verba transitif, yaitu verba yang ber prefiks me(dapat diganti dengan di-, prefiks ter-, dan prefiks zero). Contohnya pada kata mendaratkan bentuk pangkalnya adalah daratkan, serta pada kata mencuci pangkalnya adalah cuci.

Akar (root) digunakan untuk menyebut bentuk yang tidak dapat dianalisis lebih jauh lagi. Artinya, akar merupakan bentuk yang tersisa setelah semua afiksnya ditinggalkan. Misalnya pada kata memberlakukan setelah semua afiksnya ditinggalkan, yaitu me-, ber- dan -kan maka yang tersisa hanya akar laku. Akar laku ini tidak dapat dianalisis lebih jauh lagi tanpa merusak makna akar tersebut (Chaer, 2008).

Leksem digunakan dalam bidang kajian linguistik morfologi dan semantik. Dalam kajian morfologi, laksem digunakan untuk mewadahi konsep bentuk yang menjadi kata 
dalam proses morfologi. Sedangkan dalam kajian semantik, leksem merupakan satuan bahasa yang memiliki sebuah makna. Dalam proses morfologi, misalnya dalam bentuk PUKUL (Leksem dalam konversi morfologi ditulis dengan huruf kapital semua) menurunkan kata misalnya memukul, dipukul, terpukul, pukulan, pukul, pemukul, dan pemukulan (Chaer, 2008).

\section{F. PROSES MORFEMIS}

Dalam proses morfologi melibatkan beberapa komponen yang meliputi bentuk dasar, pembentuk kata (afiksasi, reduplikasi, komposisi, akronimisasi, dan konversi), makna gramatikal, serta hasil dari proses pembentukan.

a. Bentuk dasar

Bentuk dasar dapat berupa akar dan polimorfemis. Dalam proses reduplikasi, bentuk dasar dapat berupa akar dan berupa kata imbuhan. Bentuk dasar yang berupa akar,misalnya pada kata rumah-rumah, akarnya adalah rumah, kata marah-marah, akarnya adalah marah. Bentuk dasar yang berupa imbuhan, misalnya kata kemerahmerahan, dari karta kemerahan, menembak-nembak, dari kata menembak.

Dalam bentuk komposisi, bentuk dasar bisa berupa akar atau dua buah akar. Bentuk dasar berupa satu akar, misalnya akar sate pada kata sate ayam,dan sate lilit. Bentuk dasar berupa dua buah akar, misalnya akar kampung dan akar halaman pada kata kampung halaman. 
b. Pembentuk kata

Pembentuk kata dalam proses morfologi berupa (a) afiksasi, (b) reduplikasi, (c) komposisi, (d) akronimisasi, dan (e) konversi.

(a) Afiksasi.

Afiksasi merupakan proses pembubuhan afiks pada bentuk dasar. Bentuk dasar yang menjadi dasar dalam proses afiksasi bisa berupa akar, bentuk kompleks atau bisa berupa frasa. Bentuk dasar yang berupa akar misalnya meja, kursi, dan tidur. Sedangkan yang berbentuk kompleks misalnya terbelakang pada kata keterbelakangan, berlaku pada kata memberlakukan. Contoh pembentukan yang berupa frasa yaitu pada kata ikut serta dalam kata keikutsertaan, tiba di Malang, pada setiba di Malang.

Berdasarkan sifat kata yang dibentuknya afiks dibedakan menjadi dua jenis, yaitu afiks inflektif dan afiks derivatif (Chaer, 2012). Afiks inflektif merupakan afiks yang digunakan dalam pembentukan kata-kata inflektif, misalnya dalam bahasa Indonesia dibedakan adanya prefiks me- yang inflektif, dan me- yang derivatif. Prefiks me- dalam afiks inflektif menandai bentuk kalimat aktif, sedangkan prefiks di- menandakan bentuk pasif. Sebagai afiks derivatif, prefiks me- membentuk kata baru, yaitu identitas leksikalnya tidak sama dengan bentuk dasarnya, misalnya kata membungkuk yang berkelas verba yang berasal dari dasar ajektif atau kata sifat, kata memahat yang berkelas verba dari dasar nomina atau kata benda. Dalam bahasa Inggris juga terdapat contoh pembentukan kata inflektif, misalnya sufiks $-\mathrm{s}$ pada kata pencils 
merupakan penanda jamak, atau sufiks -ed pada kata walked merupakan penanda lampau.

Jika dilihat dari proses melekatnya pada kata dasar, proses afiksasi dibedakan menjadi beberapa jenis, yaitu prefiks, infiks, sufiks, dan konfiks, interfiks, dan juga transfiks (Chaer, 2012). Prefiks, yaitu imbuhan (afiks) yang dibubuhkan disebelah kiri atau di depan kata dasar, yaitu prefiks ber-, me-, per-, di-, ter-, se-, dan ke-. Misalnya kata menghibur, terdapat prefiks me-. Prefiks dapat muncul bersamaan dengan sufiks atau afiks lain, misalnya prefiks ber-, dengan sufiks -kan pada kata berdasarkan.

Infiks, yaitu imbuhan yang dibubuhkan di tengah kata dasar, misalnya -el-, -em-, dan

-er-, misalnya pada kata suling terdapat sufiks -er, kata tunjuk terdapat sufiks -el.

Sufiks, merupakan imbuhan yang dibubuhkan di sebelah kanan atau di akhir kata dasar, yaitu $-k a n,-i$, -an, dan nya. Sebagai contoh pada kata bagikan, terdapat sufiks kan. Contoh dalam bahasa Inggris misalnya pada kata constitution terdapat sufiks -ion.

Konfiks, yaitu imbuhan yang dibubuhkan di sebelah kiri dan kanan kata dasar secara bersamaan karena merupakan satu kesatuan afiks. Misalnya ke-an, ber-an, pe-an, per-an, dan se-nya.

Dalam linguistik, penggunaan istilah sirkumfiks tidaklah sama. Sirkumfiks digunakan untuk menyebut gabungan afiks yang bukan konfiks, misalnya ber- 1 -an pada kata beraturan, kata ini memiliki arti mempunyai aturan. Adapun yang dimaksud dengan interfiks yaitu 
sejenis infiks atau elemen penyambung yang muncul dalam proses penggabungan dua buah unsur. Interfiks banyak dijumpai pada bahasa Indo German. Transfiks yaitu afiks yang berwujud vokal yang diimbuhkan pada keseluruhan dasar. Transfik bisa dijumpai pada bahasa Semit (Arab dan Ibrani).

(b) Reduplikasi

Reduplikasi biasanya disebut dengan istilah kata ulang. Bentuk pengulangan dalam proses reduplikasi bisa terjadi secara keseluruhan, sebagian, maupun dengan perubahan bunyi. Contoh reduplikasi secara keseluruhan yaitu kata kursi-kursi, dari kata dasar kursi. Reduplikasi parsial atau sebagian contohnya lelaki, dari kata dasar laki, sedangkan contoh reduplikasi dengan perubahan bunyi yaitu bolakbalik dari kata dasar balik. Menurut Chaer (2012), ada beberapa hal yang perlu diperhatikan mengenai proses reduplikasi, yaitu:

Pertama, bentuk dasar reduplikasi bisa berupa morfem dasar, bentuk berimbuhan, dan bentuk gabungan kata. misalnya kursi, menjadi kursi-kursi. Contoh reduplikasi dari morfem dasar yaitu kata buku, setelah mengalami reduplikasi menjadi buku-buku. Reduplikasi dari bentuk berimbuhan misalnya pembangunan menjadi pembangunan-pembangunan. Sedangkan contoh reduplikasi dari bentuk gabungan misalnya surat kabar, menjadi surat-surat kabar.

Kedua,reduplikasi yang disertai afiks yang terjadi secara bersamaan, misalnya berkilo-kilo meter, reduplikasi kemudian disusul afiks,misalnya mengingat-ingat, atau 
afiksasi terlebih dahulu lalu diikuti oleh reduplikasi, misalnya kesatuan-kesatuan.

Ketiga, reduplikasi bisa terjadi secara penuh ataupun parsial. Reduplikasi secara penuh misalnya rumah-rumah susun. Sedangkan reduplikasi parsial contohnya sawah ladang-sawah ladang.

Keempat, reduplikasi bisa bersifat paradigmatis dan hanya memberi makna jamak atau kevariasian, serta bersifat derivasional misalnya kamu-kamu, merekamereka, dan sebagainya.

Kelima, reduplikais semantis, yaitu dua buah kata yang maknanya bersinonim membentuk satu kesatuan gramatikal,misalnya hancur lebur, alim ulama.

\section{(c) Komposisi}

Komposisi merupakan hasil dan proses penggabungan antar morfem dasar baik morfem yang terikat maupun bebas sehingga akan terbentuk sebuah konstruksi yang memiliki identitas leksikal yang baru, misalnya lalu lalang, rumah bersalin.

\section{(d) Akronimisasi}

Akronimisasi merupakan kependekan yang berupa gabungan huruf, suku kata, frasa,yang ditulis dan dilafalkan seperti kata, misalnya Jakarta Bogor Ciawi menjadi Jagorawi.

\section{(e) Konversi}

Konversi merupakan proses pembentukan kata dari sebuah kata menjadi kata lain tanpa perubahan unsur 
segmental. Misalnya sapu merupakan kata benda apabila terdapat dalam kalimat sapu ini terbuat dari ijuk, akan tetapi kata tersebut bisa berubah status menjadi kata kerja jika terdapat dalam kalimat sapu dulu lantai dapur itu.

\section{c. Makna gramatikal}

Makna gramatikal merupakan makna memiliki hubungan erat dengan komponen makna yang dimiliki oleh bentuk dasar yang terlibat dalam proses pembentukan kata. Makana gramatikal baru akan muncul dalam proses gramatika baik secara morfologi maupun sintaksis. Setiap makna gramatikal dalam suatu proses morfologi akan tampak makna maupun bnetuk dasarnya misalnya kata berkuda, maknanya mengendarai kuda.

\section{d.Tahap pembentukan}

Berdasarkan tahapan prosesnya, tahap pembentukan ini dapat dibedakan menjadi tiga proses, yaitu pembentukan setahap, bertahap, dan melalui bentuk perantara. Pembentkan setahap terjadi apabila bentuk dasarnya berupa akar atau morfem dasar (bebas atau terikat). Misalnya pengimbuhan me-pada kata beli menjadi membeli.

Pembentukan bertahap terjadi apabila bentuk dasar yang mengalami proses morfologi itu berupa bentuk polimorfemis yang sudah menjadi kata baik kata berimbuhan, berulang, maupun kata gabungan). Misalnya kata pakaian, jika ditambahkan prefiks ber- menjadi berpakaian. Pembentukan kata melalui bentuk perantara seperti terjadi pada kata perbaikan, dibentuk dari akar baik, 
lalu dengan konfiks per -an melalui verba memperbaiki. Perhatikan bagan berikut:

baik $\longrightarrow$ memperbaiki $\longrightarrow$ perbaikan

\section{G. MORF DAN ALOMORF}

Morf dan alomorf merupakan dua buah nama untuk untuk sebuah bentuk yang sama. Morf bisa dikatakan sebagai nama untuk sebuah bentuk yang belum diketahui statusnya (misal: $\{i\}$ pada kenai); sedangkan alomorf adalah nama untuk bentuk tersebut kalau sudah diketahui statusnya. Atau bisa didefinisikan sebagai anggota satu morfem yang memiliki wujud berbeda, akan tetapi yang mempunyai fungsi dan makna yang sama. Dengan kata lain alomorf adalah perwujudan konkret (di dalam penuturan) dari sebuah morfem. Jadi setiap morfem tentu mempunyai alomorf, entah satu, dua, atau enam buah. Contohnya, morfem meN- (dibaca: me-nasal): me-, mem- men-, meny-, meng-, dan menge-. Secara fonologis, bentuk meberdistribusi, antara lain, pada bentuk dasar yang fonem awalnya konsonan /I/ dan /r/; bentuk mem- berdistribusi pada bentuk dasar yang fonem awalnya konsonan /b/ dan juga $/ \mathrm{p} /$; bentuk men- berdistribusi pada bentuk dasar yang fonem awalnya /d/ dan juga /t/; bentuk meny- berdistribusi pada bentuk dasar yang fonem awalnya /s/; bentuk mengberdistribusi pada bentuk dasar yang fonem awalnya, antara lain konsonan /g/ dan /k/; dan bentuk menge- berdistribusi pada bentuk dasar yang ekasuku, contohnya [menge]+[cat] $=$ mengecat. Bentuk-bentuk realisasi yang berlainan dari morfem yang sama tersebut disebut alomorf. 


\section{H. RANGKUMAN}

a. Morfologi merupakan cabang linguistik yang mengidentifikasi satuan-satuan dasar bahasa sebagai satuan gramatikal

b. Morfologi mengkaji berbagai hal yang berkaitan dengan satuan-satuan morfologi, proses morfologi serta alat-alat dalam proses morfologi.

c. Morfem adalah satuan bahasa atau gramatikal terkecil yang memiliki makna.

d. Beberapa pedoman yang bisa dijadikan sebagai acuan untuk menentukan sebuah morfem atau bukan diantaranya:

- Dua bentuk yang sama atau lebih jika memiliki makna yang sama merupakan sebuah morfem

- Dua bentuk yang sama atau lebih jika memiliki makna yang berbeda merupakan morfem yang berbeda.

- Dua buah bentuk yang berbeda, tapi memiliki makna yang sama, merupakan dua morfem yang berbeda.

- Bentuk-bentuk yang mirip atau sedikit berbeda tetapi memiliki makna yang sama merupakan sebuah morfem yang sama, asalkan perbedaan bentuk tersebut bisa dapat dijelaskan secara fonologis.

- Bentuk yang hanya muncul dengan pasangan satu satunya merupakan sebuah morfem.

- Bentuk yang muncul berulang-ulang pada satuan yang lebih besar apabila memiliki makna yang sama merupakan morfem yang sama.

- Bentuk yang muncul berulang-ulang pada satuan bahasa yang yang lebih besar (kausa, kalimat) apabila maknanya berbeda secara polisemi merupakan morfem yang sama. 
e. Morfem bebas, yaitu morfem yang dapat berdiri sendiri dari segi makna tanpa harus dihubungkan dengan morfem yang lain.

f. Morfem terikat merupakan morfem yang tidak dapat berdiri sendiri dari segi makna.

g. Morfem utuh secara fisik merupakan satu kesatuan yang utuh. Yang termasuk morfem utuh yaitu semua morfem dasar, baik bebas maupun terikat, serta prefiks, infiks, dan sufiks.

h. Morfem terbagi yaitu morfem yang disisipi oleh morfem lain atau bisa dikatakan bentuk fisiknya telah terbagi. Yang termasuk morfem terbagi yaitu semua konfiks (pe-an, kean, dan per-an).

i. Morfem segmental merupakan morfem yang dibentuk oleh fonem-fonem segmental seperti morfem \{lihat\}, $\{$ lah $\}$, \{sikat $\}$, dan $\{$ ber $\}$.

j. Morfem suprasegmental adalah morfem yang dibentuk oleh unsur-unsur suprasegmental seperti tekanan, nada, durasi, dan sebagainya.

k. Bentuk dasar (base) merupakan bentuk yang langsung menjadi dasar dalam proses morfologi, yang bisa berwujud morfem tunggal atau dalam bentuk polimorfemis (gabungan morfem).

1. Afiksasi merupakan proses pembubuhan afiks pada bentuk dasar.

m. Afiks inflektif merupakan afiks yang digunakan dalam pembentukan kata-kata inflektif.

n. Prefiks yaitu imbuhan (afiks) yang dibubuhkan disebelah kiri atau di depan kata dasar. 
o. Infiks yaitu imbuhan yang dibubuhkan di tengah kata dasar.

p. Sufiks merupakan imbuhan yang dibubuhkan di sebelah kanan atau di akhir kata dasar.

q. Konfiks, yaitu imbuhan yang dibubuhkan di sebelah kiri dan kanan kata dasar secara bersamaan karena merupakan satu kesatuan afiks.

r. Transfiks yaitu afiks yang berwujud vokal yang diimbuhkan pada keseluruhan dasar.

s. Komposisi merupakan hasil dan proses penggabungan antar morfem dasar baik morfem yang terikat maupun bebas sehingga akan terbentuk sebuah konstruksi yang memiliki identitas leksikal yang baru.

t. Akronimisasi merupakan kependekan yang berupa gabungan huruf, suku kata, frasa, yang ditulis dan dilafalkan seperti kata.

u. Konversi merupakan proses pembentukan kata dari sebuah kata menjadi kata lain tanpa perubahan unsur segmental.

v. Makna gramatikal merupakan makna memiliki hubungan erat dengan komponen makna yang dimiliki oleh bentuk dasar yang terlibat dalam proses pembentukan kata.

w. Morf merupakan nama untuk sebuah bentuk yang belum diketahui statusnya (misal: $\{\mathrm{i}\}$ pada kenai);

x. Alomorf adalah nama untuk bentuk tersebut kalau sudah diketahui statusnya.

\section{SOAL EVALUASI}

1. Diskusikan dengan teman sekelompokmu mengenai perbedaan morfem, morf, dan alomorf! 
2. Berikan masing-masing contoh morfem bebas, merfem terikat, morf, dan alomorf!

3. Jelaskan yang dimaksud dengan proses morfofonemik! Berikan contoh dari bahasa daerahmu!

4. Jelaskan perbedaan antara afiks inflektif dan afiks derivatif!

5. Berikan masing-masing contoh morfem bermakna leksikal dan morfem bermakna tak leksikal!

6. Jelaskan mengenai istilah (a) afiksasi, (b) reduplikasi, (c) komposisi, (d) akronimisasi, dan (e) konversi!

7. Berikan masing-masing contoh dari proses (a) afiksasi, (b) reduplikasi, (c) komposisi, (d) akronimisasi, dan (e) konversi! 


\section{BAB IV}

\section{FONOLOGI BAHASA INDONESIA}

\section{Tujuan Instruksional}

Mampu memahami konsep fonologi bahasa Indonesia:

fonem, alofon, dan grafem

\section{A. PENGERTIAN FONOLOGI}

Fonologi merupakan cabang ilmu bahasa yang mempelajari dan menganalisis sistem bunyi bahasa (Chaer, 2012). Fonologi mengkaji bunyi ujaran yang dihasilkan oleh alat ucap manusia. Yang dimaksud sebagai bunyi ujaran merupakan pembentukan fonem-fonem yang disatukan menjadi sebuah kata. Menurut hierarki satuan bunyi, fonologi dibedakan menjadi fonetik dan fonemis. Bunyi-bunyi ujaran merupakan unsur bahasa terkecil yang merupakan bagian dari sistem bahasa dan berfungsi untuk membedakan makna. Fonologi yang memandang bunyi-bunyi ujaran sebagai bagian dari sistem bahasa disebut fonemik (Muslich, 2008). Ruang lingkup kajian fonologi tidak hanya mengkaji beberapa bunyi bahasa dan fonem-fonemnya akan tetapi tetapi lebih luas dari itu yaitu mengkaji peran fonem tersebut dalam membentuk struktur suku kata serta penggabungan morfem dengan morfem yang lain dalam bahasa itu. Dengan kata lain bisa disimpulkan bahwa ruang lingkup fonologi berawal dari penemuan bunyi bahasa, yaitu menyelidiki alat ucap yang menghasilkanya dan pembentukannya sehingga ditemukannya bunyi-bunyi bahasa itu. Berikut akan dibahas mengenai kajian fonologi.

a. Fonetik 
Fonetik merupakan ilmu bahasa yang mempelajari bunyi bahasa (fon) yang dihasilkan alat ucap manusia tanpa memperhatikan apakah bunyi tersebut mempunyai fungsi sebagai pembeda makna atau tidak (Chaer, 2012). Menurut proses terjadinya bunyi bahasa, fonetik dibedakan menjadi tiga macam, yaitu fonetik artikulatoris, fonetik akustik, dan fonetik auditoris. Kridalaksana (2008) menjelaskan fonetikfonetik sebagai berikut :

a) Fonetik artikulatoris adalah cabang fonetik yang menyelidiki bunyi yang dihasilkan oleh alat ucap manusia. Dalam hal ini fonetik artikulatoris mempelajari bagaiamana mekanisme alat-alat bicara manusia bekerja dalam menghasilkan bunyi bahasa dan bagaimana bunyi tersebut diklasifikasikan.Fonetik artikulatoris disebut juga sebagai fonetik organis atau fonetik fisiologis.

b) Fonetik akustik adalah cabang fonetik yang mempelajari ciri-ciri fisik bunyi bahasa sebagai peristiwa fisis atau fenomena alam. Bunyi-bunyi tersebut diselidiki frekuensi getarannya, amplitudonya, intensitasnya serta timbrenya. Alat-alat yang digunakan untuk mengkaji gelombang bunyi bahasa dan mengukur pergerakan udara yaitu spektograf (alat yang digunakan untuk menganakisis dan memaparkan frekuensi dan tekanan), sedangkan oscilloscop yaitu alat yang digunakan untuk memaparkan ciriciri kenyaringan bunyi.

c) Fonetik audiotoris adalah cabang fonetik yang mempelajari bagaimana mekanisme penerimaan bunyi itu oleh pendengaran kita.

Dari ketiga jenis fonetik tersebut yang paling berurusan dengan dunia lingusitik adalah fonetik artikulatoris, karena 
fonetik tersebut berkenaan dengan masalah bagaimana bunyibunyi bahasa itu dihasilkan atau diucapkan oleh manusia. Sedangkan fonetik akustik lebih berkenaan dengan bidang fisika, dan fonetik auditoris berkenaan dengan bidang kedokteran.

\section{Fonemik}

Fonemik adalah ilmu bahasa yang membahas bunyi bahasa yang berfungsi membedakan makna kata (Chaer, 2012). Jika dalam fonetik mempelajari segala macam bunyi yang dapat dihasilkan oleh alat ucap serta bagaimana tiap-tiap bunyi itu dilaksanakan, maka dalam fonemik membahas dan menyelidiki kemungkinan bunyi ujaran yang manakah yang dapat mempunyai fungsi untuk membedakan arti. Chaer (2007) menjelaskan bahwa fonemik mengkaji bunyi bahasa yang mampu atau berfungsi membedakan makna kata.

\section{B. PENGERTIAN DAN JENIS FONEM}

Fonem adalah kesatuan terkecil suatu bahasa yang berfungsi membedakan makna (Muslich, 2008). Menurut Maksan (1994) bahwa dalam suatu bahasa, fonem mempunyai distribusi tertentu yang memiliki perbedaan dengan bahasa lain. Sebuah fonem dapat berada di posisi awal, tengah, dan akhir dari sebuah kata. Akan tetapi, fonemfonem tertentu hanya mampu menempati posisi tertentu saja, misalnya hanya bisa menempati posisi tengah saja atau bahkan tidak dapat menempati posisi akhir, dan sebagainya. Chaer (2009), menjelaskan bahwa distribusi fonem merupakan kemampuan fonem untuk berada pada posisi tertentu dalam sebuah kata dasar. Dalam bahasa, fonem akan 
membentuk tuturan, sedangkan kombinasi beberapa fonem akan membentuk suku kata dan suku kata pada akhirnya akan membentuk kata, sedangkan kata akan membentuk kalimat dan tuturan. Menurut Chaer (1994) untuk mengidentifikasi apakah sebuah bunyi merupakan fonem atau bukan, maka langkah yang ditempuh yaitu harus mencari sebuah satuan bahasa atau sebuah kata yang mengandung bunyi tersebut lalu membandingkannya dengan satuan bahasa yang lain yang mirip dengan satuan bahasa yang pertama. Apabila kedua satuan bahasa tersebut memiliki perbedaan makna, berarti bunyi tersebut adalah fonem karena ia bisa atau berfungsi membedakan makna kedua satuan bahasa itu. Sebagai contoh dalam kata "murah dan "lurah", kedua kata itu sangat mirip, masing-masing terdiri dari lima bunyi yaitu [m], [u], [r], [a], dan [h],serta [1],[u],[r],[a], dan [h]. Jika kedua bunyi tersebut dibandingkan ternyata perbedaannya hanya pada bunyi $[\mathrm{m}]$ dan [1], akan tetapi kedua kata tersebut memiliki arti yang berbeda. Dengan demikian dapat diambil kesimpulan bahwa bunyi [m] dan [1] adalah fonem yang berbeda dalam bahasa Indonesia.

Dalam ilmu bahasa bahwa fonem setiap bahasa terbagi atas fonem segmental dan fonem suprasegmental (Kentjono, 1982 ; Pateda, 1990, Verhaar, 1996). Fonem segmental merupakan jenis fonem yang keberadaannya dapat dianalisa. Fonem ini terdiri dari vokal dan konsonan. Sedangkan fonem suprasegmental adalah fonem yang harus berada bersamasama dengan fonem segmental. Fonem suprasegmental meliputi tekanan (stress), nada (pitch), panjang (length) dan jeda (juncture). Tekanan (stress) merupakan kuat lemahnya suara ketika suatu bunyi difonasikan. Panjang (length) adalah 
lamanya bunyi dilafalkan. Nada (pitch) berkaitan dengan tinggi rendahnya suara atau bunyi jika terdapat pengucapan dengan fonem yang sama, tapi nada ucapannya berbeda, maka akan berbeda makna. Lambang teknisnya adalah tanda [:]. Samsuri (1991) menyebut fonem suprasegmental sebagai prosodi, sedangkan Bloomfield (1995) menyebutnya fonem sekunder.

\section{ALOFON}

Chaer (1994) menjelaskan bahwa alofon merupakan realisasi bunyi dari sebuah fonem. Sedangkan Suparno (2002) menjelaskan bahwa sifat alofon ialah fonetis, jadi tidak membedakan arti. Dalam bahasa Indonesia fonem /i/ memiliki empat buah alofon, yaitu bunyi [i] dalam kata cita, bunyi [I] dalam kata tarik. Beberapa alofon dari sebuah fonem memiliki kemiripan fonetis, yang berarti bahwa banyak memiliki kesamaan dalam pengucapannya, atau jika diliohat dalam peta fonem, letaknya masih berdekatan.

\section{GRAFEM}

Grafem merupakan satuan terkecil dalam aksara yang menggambarkan fonem (Chaer, 1994). Sedangkan Nurhadi (1995) menjelaskan bahwa grafem adalah perlambang fonem yang berbentuk huruf. Sedangkan fonem lebih merujuk pada bunyi bahasa, misalnya kata buku terdiri atas empat grafem yaitu $\langle\mathrm{b}\rangle,\langle\mathrm{u}\rangle,\langle\mathrm{k}\rangle,\langle\mathrm{u}\rangle$, dan terdiri dari tiga grafem yaitu $/ \mathrm{b} /, / \mathrm{u} /, / \mathrm{k} /$. 


\section{E. KLASIFIKASI BUNYI}

Bunyi bahasa dibedakan menjadi dua jenis yaitu bunyi vokal dan konsonan. Bunyi vokal dihasilkan dengan pita suara sedikit terbuka kemudian bergetar saat dilalui arus udara yang dipompakan dari paru-paru. Setelah itu, arus udara tersebut keluar melalui rongga mulut tanpa mengalami hambatan apapun. Sedangkan bunyi konsonan dihasilkan setelah adanya arus udara yang melewati pita suara yang terbuka sedikit atau agak lebar lalu diteruskan ke rongga mulut atau rongga hidung dengan mendapat hambatan ditempat-tempat tertentu. Jadi bisa bisa disimpulkan bahwa perbedaan antara bunyi vokal dan konsonan yaitu pada proses adanya arus udara dalam pembentukan bunyi vokal tidak ada hambatan apapun setelah melewati pita suara, sedangkan pada bunyi konsonan arus udara yang melewati pita suara mendapat hambatan atau gangguan. Semua bunyi vokal menghasilkan suara karena dihasilkan dengan pita suara yang sedikit terbuka, sedangkan bunyi konsonan ada yang menghasilkan suara da nada yang tidak. Apabila menghasilkan suara artinya pita suara sedikit terbuka, dan apabila tidak menghasilkan suara berarti pita suara terbuka agak lebar. Berdasarkan hasil penelitian, bahasa Indonesia memiliki kurang lebih 6 fonem vokal dan 22 fonem konsonan (Muslich, 2012).

\section{a. Klasifikasi Vokal}

Bunyi vokal diklasifikasikan dan diberi nama berdasarkan posisi lidah dan bentuk mulut. Posisi lidah bisa bersifat vertical atau horizontal. Apabila bersifat vertical maka bisa diklasifikasikan menjadi vokal tinggi, vokal 
tengah, dan vokal rendah. Vokal tinggi misalnya bunyi [i] dan $[u]$, vokal tengah misalnya bunyi $[\mathrm{e}]$ dan $[\partial]$ dan vokal rendah misalnya bunyi [a]. secara horizontal maka bisa dibedakan menjadi bunyi vokal depan, vokal pusat, dan vokal belakang. Vokal depan misalnya bunyi [i] dan [e], vokal pusat misalnya bunyi $[\partial]$, dan vokal belakang misalnya bunyi $[\mathrm{u}]$ dan [o]. Apabila ditinjau dari bentuk mulut maka dbunyi vokal dibedakan menjadi dua jenis, yaitu vokal bundar (bentuk mulut membundar saat mengucapkan vokal tersebut) dan vokal tak bundar (bentuk mulut tidak membundar/ melebar saat melafalkan vokal tersebut). Yang termasuk vokal bundar yaitu bunyi [o] dan [u], sedangkan vokal tak bundar misalnya vokal [e] dan dan [i].

Selain beberapa bunyi vokal di atas, ada istilah diftong atau vokal rangkap. Disebut sebagai vokal rangkap karena saat memproduksi bunyi tersebut posisi lidah tidak sama pada bagian awal dan bagian akhir. Ketidaksamaan tersebut diakibatkan adanya tinggi rendahnya lidah, bagian lidah yang bergerak, dan struktur lidah. Bunyi yang dihasilkan bukanlah dua buah bunyi akan tetapi sebuah bunyi karena berada dala satu silabel, misalnya bunyi [au], dan [ai]. Diftong dibedakan menjadi dua jenis yaitu diftong naik dan diftong turun. Diftong naik yaitu bunyi pertama yang dihasilkan posisinya lebih rendah dari pada bunyi kedua. Sedangkan diftong turun yaitu bunyi pertama yang dihasilkan lebih tinggi dari pada bunyi kedua.

b.Klasifikasi Konsonan

Bunyi konsonan dibedakan berdasarkan tiga kriteria yaitu posisi pita suara, tempat artikulasi, dan cara artikulasi. Jika dilihat dari posisi pita suara, bunyi konsonan dibedakan 
menjadi bunyi bersuara dan bunyi tak bersuara. Bunyi bersuara misalnya bunyi $[\mathrm{b}],[\mathrm{d}],[\mathrm{g}]$, dan [c]. Sedangkan bunyi tak bersuara misalnya bunyi $[\mathrm{s}],[\mathrm{k}],[\mathrm{p}]$, dan $[\mathrm{t}]$. bunyi bersuara timbul akibat adanya getaran pada pita suara yang terbuka sedikit, sedangkan bunyi tak bersuara timbul karena pita suara terbuka agak lebar sehingga tidak terjadi getaran.

Apabila ditinjau dari tempat artikulasinya, konsonan dibagi menjadi beberapa jenis, yaitu:

1. Bilabial

Bunyi bilabial terjadi pada kedua belah bibir, yaitu bibir bawah yang merapat pada bibir atas, misalnya bunyi $[\mathrm{b}]$, [p], dan [m]. Bunyi [b] dan [p] merupakan bunyi oral karena dikeluarkan melalui rongga mulut, sedangkan bunyi [m] merupakan bunyi nasal karena dikeluarkan melalui rongga hidung.

\section{Labiodental}

Labiodendal merupakan konsonan yang terjadi pada gigi bawah serta bibir atas. Sedangkan posisi gigi bawah merapat pada bibir atas. Beberapa contoh bunyi labiodental misalnya bunyi [f] dan [v].

3. Laminoalveolar

Laminoalveolar yaitu konsonan yang terjadi pada daun lidah dan gusi. Sedangkan posisi daun lidah menempel pada gusi. Beberapa contoh bunyi laminoalveolar yaitu bunyi $[\mathrm{t}]$ dan $[\mathrm{d}]$. 


\section{Dorsovelar}

Dorsovelar yaitu konsonan yang terjadi pada pangkal lidah dan velum (langit-langit lunak). Beberapa contoh bunyi dorsovelar yaitu bunyi $[\mathrm{k}]$ dan $[\mathrm{g}]$.

Sedangkan ditinjau dari cara artikulasinya (bagaimana gangguan atau hambatan yang dilakukan terhadap arus udara) bunyi konsonan dibagi menjadi beberapa jenis, yaitu:

1. Hambat (letupan / plosive / stop)

Bunyi hambat terjadi apabila articulator menutup aliran udara sepenuhnya, sehingga mengakibatkan udara terhambat atau mampat dibelakang tempat penutupan itu. Setelah itu, penutupan tersebut dibuka secara tiba-tiba sehingga mengakibatkan adanya letupan. Beberapa contoh bunyi konsonan letupan yaitu bunyi [p], [b], [t], [d], [k], dan [g].

2. Geseran / frikatif

Bunyi geseran terjadi apabila aktikulator aktif mendekati articulator pasif sehingga membentuk celah sempit sedangkan udara yang lewat mendapat gangguan pada celah tersebut. Beberapa contoh bunyi geseran yaitu bunyi [f], [s], dan [z].

3. Paduan / frikatif

Bunyi paduan terjadi apabila articulator aktif menghabat aliran udara sepenuhnya, kmeudian membentuk celah sempit dengan articulator pasif. Beberapa contoh bunyi paduan yaitu bunyi [c] dan [j].

4. Sengauan / nasal

Bunyi sengauan terjadi apabila articulator sepenuhnya menghambat aliran udara melalui mulut akan tetapi 
membiarkannya keluar melalui rongga hidung dengan bebas. Beberapa contoh buyi sengauan yaitu bunyi $[\mathrm{m}],[\mathrm{n}]$, dan $[\mathrm{\eta}]$.

5. Getaran / trill

Bunyi getaran terjadi apabila articulator aktif melakukan kontak beruntun dengan artikulatorpasif, sehingga terjadi getaran bunyi yang berulang-ulang. Beberapa contoh bunyi getaran yaitu bunyi [r].

6. Sampingan / lateral

Bunyi sampingan terjadi apabila articulator aktif menghambat aliran udara pada bagian tengah mulut, kemudian membiarkan udara tersebut keluar melalui samping lidah. Beberapa contoh bunyi sampingan yaitu bunyi [1].

7. Hampirn / aproksiman

Bunyi hampiran terjadi apabila articulator aktif dan pasif membentuk ruang yang mendekati posisi terbuka seperti dakam pembentukan vokal, akan tetapi tidak cukup sempit untuk menghasilkan konsonan geseran. Contoh bunyi geseran yaitu [w] dan $[y]$.

\section{F. RANGKUMAN}

a. Fonologi merupakan ilmu yang mengkaji bunyi ujaran yang dihasilkan oleh alat ucap manusia.

b. Fonetik merupakan ilmu bahasa yang mempelajari bunyi bahasa (fon) yang dihasilkan alat ucap manusia tanpa memperhatikan apakah bunyi tersebut mempunyai fungsi sebagai pembeda makna atau tidak 
c. Fonetik artikulatoris adalah cabang fonetik yang menyelidiki bunyi yang dihasilkan oleh alat ucap manusia.

d. Fonetik audiotoris adalah cabang fonetik yang mempelajari bagaimana mekanisme penerimaan bunyi itu oleh pendengaran kita.

e. Fonemik adalah ilmu bahasa yang membahas bunyi bahasa yang berfungsi membedakan makna kata.

f. Fonem adalah kesatuan terkecil suatu bahasa yang berfungsi membedakan makna.

g. Fonem segmental merupakan jenis fonem yang keberadaannya dapat dianalisa. Fonem ini terdiri dari vokal dan konsonan.

h. Fonem suprasegmental adalah fonem yang harus berada bersama-sama dengan fonem segmental.

i. Alofon merupakan realisasi bunyi dari sebuah fonem.

j. Grafem merupakan satuan terkecil dalam aksara yang menggambarkan fonem.

k. Bunyi bahasa dibedakan menjadi dua jenis yaitu bunyi vokal dan konsonan.

1. Apabila ditinjau dari tempat artikulasinya, konsonan dibagi menjadi beberapa jenis, yaitu:bilabial, labiodental, laminoalveolar, dan dorsovelar.

m. Ditinjau dari cara artikulasinya (bagaimana gangguan atau hambatan yang dilakukan terhadap arus udara) bunyi konsonan dibagi menjadi beberapa jenis, yaitu:hambat/ letupan, geseran / frikatif, paduan/ frikatif, sengauan/ nasal, getaran/trill, sampingan /lateral, dan hampiran/aproksiman. 


\section{G.SOAL EVALUASI}

1. Diskusikan dengan teman sekelompokmu mengenai perbedaan antara fonem, alofon, dan grafem!

2. Berikan masing-masing contoh bunyi fonem alofon, dan grafem!

3. Hitunglah jumlah fonem yang ada pada kata :
a. Menari
b. Pusing
c. Mengkhawatirkan

4. Apa yang dimaksud dengan alofon? Apakah setiap fonem memiliki alofon?

5. Mengapa kriteria klasifikasi dan penamaan fonem sama dengan kriteria untuk klaifikasi dan penamaan fon?

6. Jelaskan perbedaan antara asimilasi fonetis dan asimilasi fonemis! Berikan contohnya!

7. Jelaskan mengenai proses bunyi vokal dan bunyi konsonan!

8. Berikan contoh bunyi diftong naik dan diftong turun!

9. Jelaskan perbedaan antara konsonan labiodental dengan laminoalveolar, dan berikan masing-masing dua contoh bunyi tersebut!

10. Jelaskan terjadinya proses bunyi geseran!

11. Berikan masing-masing dua contoh bunyi sengauan dan hampiran! 


\section{BAB V}

\section{KALIMAT}

\section{Tujuan Instruksional:}

Mampu memahami dan menganalisis komponen kalimat, jenis kalimat, jenis paragraf, serta pengembangan kalimat dan paragraf

\section{A. PENGERTian Kalimat}

Kalimat merupakan satuan sintaksis yang tersusun atas konstituen dasar berupa klausa dan dilengkapi dengan konjungsi, serta disertai dengan intonasi akhir (Chaer, 2012). Sedangkan Ramelan (1987) mendefinisikan kalimat sebagai satuan gramatikal yang dibatasi oleh jeda panjang yang disertai nada akhir turun atau naik. Kalimat bisa berwujud lisan atau tulisan yang mengungkapkan pikiran yang utuh dan kata-kata yang teratur. Dari definisi di atas dapat disimpulkan bahwa dalam kalimat yang paling penting adalah adanya konstituen dasar yang berupa klausa, frasa, atau kata serta intonasi akhir, karena konjungsi hanya ada jika diperlukan. Jika sebuah klausa diberi intonasi akhir maka akan membentuk kalimat. Kalimat yang terdiri dari konstituen dasar berupa klausa maka kalimat tersebut disebut sebagai kalimat mayor atau kalimat bebas. Akan tetapi jika sebuah kalimat terdiri dari konstituen dasar berupa kata atau frasa, maka kalimat tersebut menjadi kalimat terikat. 


\section{B. JENIS KALIMAT}

a. Kalimat Inti dan Kalimat Non Inti

Kalimat inti atau kalimat dasar merupakan kalimat yang terbentuk dari klausa inti lengkap. Klausa inti tersebut bisa bersifat deklaratif, aktif, serta afirmatif (Chaer, 2012). Pola atau struktur kalimat inti biasanya tersusun atas:

1. Frasa nominal + frasa verbal

Contoh: Paman pergi.

2. Frasa nominal + frasa verbal + frasa nominal Contoh : Paman membeli baju.

3. Frasa nominal + frasa verbal + frasa nominal + frasa nominal

Contoh : Paman membelikan adik baju.

4. Frasa nominal + frasa nominal

Contoh: Paman petani.

5. Frasa nominal + frasa ajektifal

Contoh: Paman rajin.

6. Frasa nominal + frasa numeral

Contoh : Uangnya empat juta.

7. Frasa nominal + frasa preposisi

Contoh: Uangnya di brangkas.

Kalimat non inti terjadi karena adanya proses transformasi dari kalimat inti. Kalimat inti bisa diubah menjadi kalimat non inti dengan berbagai proses, misalnya proses transformasi pemasifan, pengingkaran, penanyaan, perintah, dan sebagainya (Chaer, 2012).

- Contoh proses transformasi pemasifan: 
Paman membeli baju, mengalami proses transformasi pemasifan menjadi Baju dibeli Paman.

- Contoh proses transformasi pengingkaran:

Paman membeli baju, mengalami proses transformasi pengingkaran menjadi: Paman tidak membeli

\section{b. Kalimat Tunggal dan Kalimat Majemuk}

Berdasarkan jumlah klausanya, kalimat dibedakan mejadi dua jenis, yaitu kalimat tunggal dan kalimat majemuk (Alwi,dkk, 2000). Kalimat tunggal merupakan kalimat yang terdiri dari satu klausa (Chaer, 2012). Unsur pembentuk kalimat tunggal atau pola kalimat tunggal terdiri dari subjek dan predikat, akan tetapi dapat diikuti dengan objek dan keterangan. Berdasarkan jenis predikatnya, kalimat tunggal dikelompokkan menjadi beberapa jenis, yaitu:

1. Kalimat nominal

Kalimat nominal yaitu kalimat yang memiliki predikat berupa kata benda.

Contoh: Ayah Petani.

$$
\begin{aligned}
& \text { Ayah }=\text { Subjek } \\
& \text { Petani }=\text { Predikat (berupa kata benda) }
\end{aligned}
$$

2. Kalimat verbal

Kalimat verbal yaitu kalimat yang memiliki predidat berupa kata kerja.

Contoh: Ayah mencangkul.

Ayah $=$ Subjek

Mencangkul $=$ Predikat (berupa kata kerja)

3. Kalimat Numeral 
Kalimat numeral yaitu kalimat yang memiliki predikat berupa kata bilangan.

Contoh: Uangnya empat juta.

Uangnya $=$ Subjek

Empat juta $=$ Predikat (berupa kata numeral / bilangan)

4. Kalimat ajektival

Kalimat ajektival yaitu kalimat yang memiliki predikat berupa kata sifat.

Contoh: Ayah pandai.

$$
\begin{aligned}
& \text { Ayah }=\text { Subjek } \\
& \text { Pandai }=\text { Predikat (berupa kata sifat) }
\end{aligned}
$$

5. Kalimat preposisional

Kalimat preposisional yaitu kalimat yang memiliki predikat berupa kata depan.

Contoh: Ayah dari Blitar.

Ayah $=$ Subjek

Dari Blitar $=$ Predikat (berupa preposisi atau kata depan)

Ramelan (1987) membagi kalimat tunggal menjadi beberapa jenis, yaitu :

1. Kalimat Tanya

Kalimat tanya yaitu kalimat yang mengandung unsur pertanyaan dan bertujuan ingin mengetahui sesuatu.

Contoh: Bapak pergi kemana?

2. Kalimat berita

Kalimat berita yaitu kalimat yang berfungsi untuk memberikan informasi atau sesuatu kepada orang lain (Ramelan, 1987). 
Contoh: Bapak membeli baju di pasar swalayan.

3. Kalimat perintah (imperatif)

Kalimat perintah yaitu kalimat yang digunakan untuk menyuruh orang lain agar melakukan sesuatu.

Contoh: Berikan baju ini ke anak yatim!

Kalimat majemuk yaitu kalimat yang terdiri dari dua klausa atau lebih. Kalimat majemuk dibagi menjadi tiga jenis, yaitu kalimat majemuk setara, kalimat majemuk bertingkat, dan kalimat majemuk campuran. Berdasarkan sifat hubungan antar klausa dalam kalimat Chaer (2012) membagi kalimat majemuk campuran menjadi beberapa jenis, yaitu kalimat majemuk koordinatif (kalimat majemuk setara), kalimat majemuk subordinatif (kalimat majemuk bertingkat), serta kalimat majemuk kompleks.

\section{Kalimat majemuk koordinatif}

Kalimat majemuk koordinatif yaitu kalimat majemuk yang terdiri dari beberapa klausa yang memiliki status yang sama atau setara. Dengan kata lain, klausa yang satu tidak menjadi bagian atau tidak menduduki fungsi tertentu bagi klausa lain. Klausa dalam kalimat majemuk setara (koordinatif) dihubungkan dengan menggunakan konjungsi dan, atau, tetapi, dan lalu.

Contoh kalimat majemuk setara (koordinatif):

- Ayah datang dan duduk di samping saya.

Kalimat tersebut terdiri dari dua klausa, yaitu klausa I "Ayah datang" dan klausa II "duduk di samping saya". Hubungan antara klausa I dengan klausa II setara atau sejajar, karena 
klausa I tidak menjadi bagian dari klausa II, dan klausa II juga tidak menjadi bagian dari klausa I.

\section{Kalimat majemuk majemuk bertingkat (subordinatif)}

Kalimat majemuk bertingkat (subordinatif) yaitu kalimat yang terdiri dari beberapa klausa yang tidak setara yaitu klausa utama (induk kalimat) dan klausa bawahan (anak kalimat). Dengan kata lain, salah satu klausanya menjadi bagian dari klausa yang lain. Klausa dalam kalimat majemuk bertingkat dihubungkan dengan mengguankan konjungsi subordinatif, misalnya kalau, meskipun, ketika, dan karena.

Contoh kalimat majemuk bertingkat (subordinatif):

- Kalau Ayah datang, Aku akan pergi.

Kalimat tersebut terdiri dari dua klausa, klausa I "Kalau ayah datang" dan klausa II "Aku akan pergi". Dari contoh kalimat tersebut dapat kita ketahui bahwa hubungan antara klausa I dan klausa II tidak sederajat. Klausa I mempunyai kedudukan yang lebih tinggi dan klausa II mempunyai kedudukan yang lebih rendah, karena hanya berfungsi sebagai keterangan bagi klausa I. Jadi, kalimat majemuk bertingkat di atas yang menjadi klausa induk (induk kalimat) adalah "Kalau Ayah datang", dan yang menjadi klausa bawahan (anak kalimat) "Aku akan pergi".

Kalimat majemuk bertingkat dibagi menjadi beberapa jenis yaitu:

a. Kalimat majemuk bertingkat hubungan waktu. Kalimat ini ditandai dengan konjungsi sejak, ketika, sampai, manakala, dan setelah. 
Contoh:

- Sewaktu Ayah pergi ke kantor, Kakak sedang membersihkan rumah.

b. Kalimat majemuk bertingkat hubungan tujuan.

Kalimat ini ditandai dengan konjungsi agar, biar, dan supaya.

Contoh:

- Kakak belajar semalaman agar ia lulus ujian.

c. Kalimat majemuk bertingkat hubungan syarat.

Kalimat ini ditandai dengan konjungsi jika, apabila, seandainya, dan andaikan.

Contoh:

- Jika Kakak lulus kuliah, Ayah akan membelikan mobil baru.

d. Kalimat majemuk bertingkat hubungan perbandingan.

Kalimat ini ditandai dengan konjungsi daripada, bagaikan, seperti, dan laksana.

Contoh:

- Kakak memilih untuk mengerjakan tugas dari pada pergi ke pusat perbelanjaan.

e. Kalimat majemuk bertingkat hubungan konsesip.

Kalimat ini ditandai dengan konjungsi walaupun, meskipun, dan sungguhpun.

Contoh:

- Ayah tetap bekerja keras walaupun Ia sedang sakit.

f. Kalimat majemuk bertingkat hubungan penyebaban. Kalimat ini ditandai dengan konjungsi sebab, karena, dan oleh karena.

Contoh: 
- Kakak mendapat hadiah mobil karena Ia lulus kuliah.

g. Kalimat majemuk bertingkat hubungan cara.

Kalimat ini ditandai dengan konjungsi dengan

Contoh:

- Ayah mengantar adik ke sekolah dengan menggunakan mobil.

\section{Kalimat majemuk kompleks (campuran)}

Kalimat majemuk kompleks yaitu kalimat yang terdiri dari tiga klausa atau lebih yang mana bias dihubungkan secara koordinatif maupun subordinatif.

Contoh kalimat majemuk kompleks (campuran):

-Aku sudah menyelesaikan pekerjan ketika Ayah pulang dari kantor dan Ibu sedang menyiapkan makan malam.

Kalimat tersebut terdiri dari tiga klausa, klausa I "Aku sudah menyelesaikan pekerjaan", klausa II "ketika Ayang pulang dari kantor" dan klausa III "Ibu sedang memasak". Hubungan klausa II dan III adalah setara, sedangkan hubungan klausa I dengan klausa II dan III adalah bertingkat. Oleh karena itu klausa klausa tersebut disebut sebagai kalimat majemuk kompleks (campuran) karena terdiri dari klausa setara dan bertingkat.

c. Kalimat Mayor dan Kalimat Minor

Berdasarkan lengkap tidaknya klausa yang menjadi konstituen dasar sebuah kalimat, maka kalimat dibagi menjadi dua jenis yaitu kalimat mayor dan kalimat minor 
(Chaer, 2012). Kalimat mayor yaitu kalimat yang memiliki klausa lengkap, yaitu sekurang-kurangnya memiliki unsur subjek dan predikat.

Contoh kalimat mayor:

- Kakak sudah makan.

$\mathrm{S} \quad \mathrm{P}$

- $\underline{\text { Ayah pergi ke Malang. }}$

$\begin{array}{lll}\mathrm{S} & \mathrm{P} & \mathrm{K}\end{array}$

Adapun yang dimaksud dengan kalimat minor yaitu kalimat yang memiliki klausa tidak lengkap (hanya terdiri dari subjek saja, predikat saja, objek saja, atau keterangan saja). Meskipun kalimat minor ini tidak memiliki klausa lengkap, akan tetapi kalimat ini dapat dipahami oleh pendengar maupun pembicara berdasarkan konteks percakapan. Beberapa contoh kalimat minor yaitu jawaban singkat, kalimat seruan, kalimat perintah, kalimat tanggapan, kalimat larangan, slogan, kalimat panggilan, dan sebagainya.

Contoh kalimat minor:

- (Sudah makan?) Belum. (Jawaban singkat)

- Wah! (Seruan)

- Pergi! (Perintah)

- Jangan! (Larangan)

- Hidup atau mati! (Slogan)

- Bu Guru! (Panggilan)

d. Kalimat verbal dan non verbal 
Berdasarkan banyaknya tipe verbanya, Chaer (2012) menjelaskan bahwa kalimat dikelompokkan menjadi beberapa jenis, yaitu kalimat transitif, kalimat intransitif, kalimat aktif, kalimat pasif, kalimat dinamis, kalimat statis, kalimat refleksif, kalimat resiprokal, dan kalimat ekuatif. Sedangkan kalimat nonverbal merupakan kalimat yang memiliki predikat selain kata kerja, misalnya predikat berupa kata benda atau frasa kata benda, kata sifat atau frasa ajektiva, frasa numeral, atau bias juga berupa frasa preposisional.

Berikut merupakan jenis-jenis kalimat verbal:

1. Kalimat transitif

Kalimat transitif yaitu kalimat yang memiliki predikat berupa kata kerja transitif dan biasanya diikuti oleh objek. Kalimat transitif bisa diikuti oleh satu atau dua objek. Apabila diikuti oleh satu objek, maka disebut sebagai monotransitif, dan apabila diikuti oleh dua objek maka disebut sebagai bitransitif.

Contoh:

- Rosa mencuci baju. (kalimat monotransitif karena terdiri dari satu objek)

- Ayah membelikan Adik baju baru. (kalimat bitransitif karena terdiri dari dua objek)

2. Kalimat intransitif

Kalimat intransitif yaitu kalimat yang memiliki predikat berupa kata kerja intransitive dan tidak memiliki objek.

Contoh:

- Kakak menari.

- Adik berlari ke dapur.

3. Kalimat aktif 
Kalimat aktif yaitu kalimat yang subjeknya berperan sebagai pelaku secara aktif (melakukan tindakan).

Contoh:

- Ayah membaca koran.

- Adik menulis surat.

4. Kalimat pasif yaitu kalimat yang subjeknya dikenai pekerjaan.

Contoh:

- Surat ditulis Adik.

- Payung dibeli oleh Kakak.

5. Kalimat dinamis

Kalimat dinamis yaitu kalimat yang secara semantik (makna) predikatnya menyatakan suatu tindakan.

Contoh:

- Pekerja pabrik itu pulang.

- Kakak pergi begitu saja.

6. Kalimat statis

Kalimat statis merupakan kebalikan dari kalimat dinamis yaitu secara semantis predikatnya menyatakan tindakan.

Contoh:

- Kakak tidur di kursi.

- Kucing kakak sudah mati.

7. Kalimat reflektif

Kalimat reflektif yaitu kalimat yang subjeknya menjadi pelaku dan sekaligus menjadi penderita.

Contoh:

- Ia memukul kepalanya.

8. Kalimat resiprokal 
Kalimat resiprokal yaitu kalimat yang memiliki arti saling berbalasan.

Contoh:

- Adik dan Kakak berebut sepatu.

9. Kalimat ekuatif

Kalimat ekuatif yaitu kalimat yang menyatakan suatu perbandingan yang sama.

Contoh:

- Rumah Kakak sama mewahnya dengan rumah Ayah.

\section{MAKNA KATA}

Makna merupakan konsep atau pengertian yang terdapat pada tanda linguistik (berupa kata atau leksem) (Chaer, 2012). Dari sudut pandang bahasa, makna dibedakan menjadi beberapa jenis, yaitu:

a. Makna leksikal, gramatikal, dan kontekstual

Makna leksikal merupakan makna yang dimiliki sebuah leksem tanpa ada konteks apapun. Dengan kata lain maksa leksikal merupakan makna yang sebenarnya. Makna leksikal sering kali disamakan dengan makna yang ada di dalam kamus. Misalnya kata air memiliki makna leksikal yaitu sejenis benda cair yang bisa digunakan untuk keperluan sehari-hari (Chaer, 2012).

Makna gramatikal merupakan makna yang terbentuk karena adanya proses gramatikal yaitu berupa afiksasi, reduplikasi, maupun komposisi. Misalnya kata dasar "tendang" mendapat prefik me- (menendang) maka kata tersebut akan mendapat makna baru yaitu "melakukan tendangan". 
Makna kontekstual yaitu makna yang muncul berdasarkan konteks tertentu. Misalnya kata "kaki" akan memiliki makana yang berbeda jika dipakai dalam konteks berbeda. Perhatikan contoh berikut:

- Kaki Ayah cidera saat bekerja di ladang.

- Nenek itu sedang mencari kayu bakar di kaki gunung Kelud.

b.Makna referensi dan non referensi

Makna referensi merupakan makna yang memiliki acuan atau referensi dalam dunia nyata, misalnya kata meja, kursi dan kuning. Kata tersebut termasuk kata referensi karena ada di dunia nyata. Sebaliknya, katakata yang tidak memiliki referensi atau acuan di dunia nyata maka termasuk sebagai makna non referensi. Misalnya kata "dan, atau, karena".

Selain makna referensi dan non referensi, terdapat makna yang disebut sebagai makna deiktik yaitu kata yang memiliki acuan tidak tetap dalam satu wujud dan bisa berpindah dari satu wujud ke wujud lain. Kata-kata yang memiliki makna deiktik misalnya pronomina (dia, saya, dan kamu), kata-kata yang menyatakan ruang (di sini, di sana, dan di situ), kata yang menyatakan waktu (sekarang, nanti, dan besok), dan kata yang menyatakan petunjuk (itu dan ini).

\section{c. Makna denotatif dan makna konotatif}

Makna denotatif pada dasarnya sama dengan makna leksikal, yaitu makna yang menyatakan makna sebenarnya. Sedangkan makna konotatif yaitu makna 
tambahan atau diluar makna sebenarnya. Makna konotatif seringkali berkaitan dengan nilai rasa dari penggunanya. Misalnya kata kurus, ramping, dan kerempeng. Kata kurus memiliki makna atau nilai rasa netral, sedangkan kata ramping memiliki makna yang positif (nilai rasa positif), dan kata kerempeng memiliki makan negative (nilai rasa negatif).

\section{d. Makna konseptual dan makna asosiatif}

Makna konseptual pada dasarnya sama dengan makna leksikal, denotatif dan makna referensial yaitu makna yang terlepas dari konteks atau asosiasi apapun. Misalnya kata buku memiliki makna kumpulan kertas atau bahan lainnya yang dijilid.

Sedangkan makna asosiatif yaitu makna yang memiliki hubungan dengan sesuatu di luar bahasa itu. Makna asosiasi pada dasarnya sama dengan makna lambang yang untuk menyatakan konsep lain. Misalnya kata merah mempunyai makna konseptual yaitu sejenis warna yang terang, sedangkan makna asosiasi sebagai lambang keberanian.

\section{e. Makna kata dan makna istilah}

Pada dasarnya setiap kata memiliki makna, akan tetapi makna kata akan lebih jelas jika berada dalam konteks tertentu (Chaer, 2012). Sedangkan makna istilah memiliki makna yang pasti meskipun tanpa konteks. Makna istilah dugunakan hanya pada bidang keilmuan tertentu, misalnya kata telinga, dalam ilmu kedokteran telinga berarti bagian dalam telinga, dan kata kuping merupakan bagian luar 
telinga. Kata kuping dan telinga secara umum berarti sama, akan tetapi dalam ilmu kedokteran kedua kata tersebut merupakan istilah yang berbeda. Seiring perkembangan bahasa, beberapa makna istilah tidak hanya digunakan dalam bidnag keilmuan saja, akan tetapi sudah menjadi kosakata umum yang sering digunakan.

f. Makna idiom dan peribahasa

Makna idiom merupakan makna yang terdiri dari beberapa unsur bahasa yang biasanya terbentuk dari gabungan kata atau frasa, dan maknanya tidak bisa diterangkan secara leksikal atau makna gramatikal (Chaer, 2012). Contoh makna idiom yaitu dalam kata meja hijau, secara leksikal kata tersebut berarti meja yang berwarna hijau, akan tetapi makna idiomnya adalah pengadilan.

Berbeda dengan makna idiom, makna dalam peribahasa bisa dilacak dari unsur-unsurnya karena peribahasa memiliki asosiasi dengan makna aslinya. Misalnya peribahasa "seperti api dalam sekam" yang bermakna kejahatan yang dilakukan secara diam-diam. Makna tersebut memiliki asosiasi bahwa api yang berada dalam sekam secara perlahan akan membakar sekam tersebut hingga habis.

\section{RELASI MAKNA}

Relasi makna merupakan hubungan semantik antara satuan bahasa yaitu berupa kata, frasa, maupun kalimat (Chaer, 2012). Relasi makna erat kaitannya dengan sinonim, antonim, polisemi, homonimi, ambiguiti, dan juga redundansi.

a.Sinonim 
Sinonim merupakan hubungan semantik yang menyatakan adanya kesamaan arti antara satu ungkapan dengan ungkapan lainnya, ungkapan tersebut bisa berupa kata, frasa atau bisa berupa kalimat (Chaer, 2012), misalnya kata manfaat memiliki persamaan arti dengan kata faedah. Sedangkan contoh persamaan arti dalam kalimat yaitu "Kakak menanam mawar di kebun", kalimat tersebut memiliki persamaan arti dengan kalimat "Mawar ditanam Kakak di kebun".

b. Antonim

Antonim yaitu ungkapan atau ujaran yang memiliki makna kebalikan atau berlawanan. Ungkapan atau ujaran tersebut bisa berupa kata, frasa, atau kalimat (Chaer, 2012). Contoh antonim terdapat pada kata baik memiliki arti yang berlawanan atau kontras dengan kata buruk. Menurut Chaer (2012) antonim dibedakan menjadi beberapa jenis jika dilihat dari sifat hubungannya. Pertama antonim yang bersifat mutlak, misalnya kata diam dan bergerak. Kata diam berarti tidak bergerak dan jika sedang bergerak artinya tidak diam. Kedua, antonym yang bersifat relatif misalnya kata besar dan kecil. Kedua kata tersebut memiliki arti yang bersifat relatif tergantung ukuran perbandingannnya. Yang kegita antonim yang bersifat relasional, misalnya kata suami dan istri, kedua kata tersebut memiliki relasi. Adanya kata suami karena ada kata istri. Contoh konkritnya seorang laki-laki tidak akan disebut sebagai suami jika tidak memiliki istri. Keempat, antonim yang bersifat hierarkial, misalnya kata kilometer dan hektometer. Kedua kata tersebut memiliki arti yang 
bersifat hierarki karena berada pada satu hirarki atau jenjang.

\section{c. Polisemi}

Polosemi merupakan ujaran yang memiliki makna lebih dari satu (Chaer, 2012). Makna dalam ujaran atau kata tersebut masih memiliki relasi antara satu dengan yang lainnya. Kata dalam polisemi ini memiliki tulisan dan pelafalan yang sama, misalnya kata kepala. Kata kepala ini bisa digunakan dalam beberapa kalimat dalam konteks yang berbeda, misalnya dalam kalimat (a) Kepala jarum itu terbuat dari plasitik, dan (b) Kepalanya terluka akibat benturan.

\section{d. Homonim}

Suatu kata atau ujaran yang memiliki ejaan dan lafal yang sama akan tetapi memiliki makna berbeda disebut sebagai homonim (Chaer, 2012). Misalnya kata bisa, memiliki arti yang berbeda yaitu bisa dalam artian sanggup dan bisa yang berarti racun ular. Dalam istilah homonim dikenal juga istilah lain yang disebut sebagai homofon dan homograf. Homofon yaitu kata yang memiliki kesamaan bunyi dengan kata lain tetapi memiliki ejaan dan makna yang berbeda. Misalnya kata bank yang berarti lembaga keuangan dan bang (bentuk singkat dari kata abang) yang berarti kakak laki-laki. Sedangkan homograf yaitu bentuk ujaran yang memiliki bentuk ejaan yang sama, tetapi pelafalan dan maknanya berbeda. Misalnya kata apel (lafal e seperti pada teh) yang berarti upacara dan kata apel (lafal e seperti pada teman) yang berarti nama buah. Perbedaan makna kata dalam polisemi dan homonim yaitu terletak pada relasi makna, 
makna kata dalam polisemi meskipun berbeda akan tetapi jika dilacak secara semantik dan etimologi, makna-makna tersebut masih memiliki hubungan. Sedangkan makna homonim tidak memiliki hubungan sama sekali.

\section{e. Hiponim}

Hiponim merupakan hubungan semantik antara ujaran atau kata yang maknanya tercakup dalam ujaran atau makna kata lainnya (Chaer, 2012) dengan kata lain kata-kata yang tingkatannya ada di bawah kata yang menjadi superordinatnya (hipernim). Misalnya terdapat pada kata-kata mangga, jeruk, apel, rambutan, kata-kata tersebut merupakan hiponim, sedangkan hipernimnya yaitu kata buah.

\section{f. Ambiguity}

Ambiguity merupakan terjadinya kegandaan makna pada kata, frasa, dan kalimat akibat tafsiran perbedaan gramatikal (Chaer, 2012). Makna ambiguity ini biasanya terjadi pada bahasa tulis, karena dalam bahasa tulis unsur intonasinya tidak ada. Contoh kalimat yang mangandung makna ambiguity yaitu "Anak guru yang pandai itu berasal dari Malang". Makna kalimat tersebut dapat ditafsirkan (1) yang pandai adalah guru, atau (2) yang pandai adalah anak guru.

g. Redundansi (kelebihan makna)

Makna redundansi merupakan makna yang penggunaannya berlebihan dalam suatu ujaran (Chaer, 2012). Misalnya dalam kalimat "Mawar itu ditanam oleh Kakak" akan memiliki makna yang sama dengan "Mawar itu ditanam Kakak". Penggunaan preposisi oleh ini dianggap berlebihan 
dalam menggunakan kata-kata. Dalam ragam bahasa baku, kita dituntut untuk menggunakan kata-kata secara efisien, sehingga kata-kata yang dianggap berlebihan harus dibuang selama tidak mengurangi makna dalam kalimat tersebut. Akan tetapi, dalam analisis semantik, setiap penggunaan unsur segmental dianggap membawa makna masing-masing. Misalnya dalam contoh kalimat di atas penggunaan preposisi oleh dianggap peran pelaku atau subjek lebih ditonjolkan, sedangkan kalimat yang tidak menggunakan preposisi oleh, peran pelaku atau subjek tidak ditonjolkan. Persamaan kedua kalimat dia atas hanya pada informasinya saja.

\section{E. PERGESERAN MAKNA BAHASA INDONESIA}

Pergeseran makna berarti adanya perubahan atau pergeseran makna suatu kata menjadi makna baru atau memiliki makna baru. Beberapa faktor yang menyebabkan adanya pergeseran makna diantaranya perkembangan ilmu dan teknologi, pengaruh sosial budaya, perbedaan bidang pemakaian, adanya penyingkatan, adanya proses gramatikal, perbedaan penafsiran, pengembangan istilah, dan sebagainya. Pergeseran makna kata dibagi menjadi beberapa jenis diantaranya:

1. Makna meluas atau generalisasi

Makna meluas terjadi apabila cakupan makna suatu kata menjadi lebih luas dari makna asalnya, misalnya kata $I b u$, kata tersebut sebelumnya memiliki makna sebutan bagi seorang wanita yang telah melahirkan seseorang. Kata $I b u$ mengalami perluasan makna menjadi panggilan bagi seseorang untuk menghormati. 
2. Makna menyempit atau spesialisasi

Makna menyempit merupakan kebalikan dari makna generalisasi, yaitu terjadi apabila cakupan makna suatu kata lebih sempit dari makna asalnya, misalnya kata sarjana, kata tersebut sebelumnya memiliki makna ahli ilmu pengetahuan atau cendekiawan. Kata tersebut mengalami penyempitan makna menjadi gelar S1.

3. Sinestesia

Sinestesia terjadi akibat adanya pertukaran anggapan antara dua indera yang berlainan. Perhatikan contoh kalimat berikut:

(a) Tutur katanya sungguh manis. (manis artinya menyenangkan)

(b) Semangka itu rasanya manis. (manis artinya rasa yang manis)

4. Ameliorasi

Makna ameliorasi terjadi apabila ada perubahan makna yang memiliki nilai rasa lebih tinggi, sopan, dan lebih baik dari makna sebelumnya, misalnya kata jamban memiliki nikai rasa yang lebih tinggi dari kata kakus.

5. Peyorasi

Peyorasi merupakan kebalikan dari ameliorasi, yaitu terjadi apabila ada perubahan makna kata yang memiliki nilai rasa yang lebih rendah, tidak sopan, dan kurang baik drai makna sebelumnya, misalnya kata bunting memiliki makna yang kurang baik dibandingkan dengan kata istri. 


\section{Asosiasi}

Asosiasi terjadi apabila ada persamaan sifat kata lama dengan kata baru yang sering bermakna kiasan. Perhatikan contoh kalimat berikut:

- Kakak sering memancing kemarahan Nenek. (kata memancing memiliki makna melakukan sesuatu agar terpenuhi keinginannya dan memiliki makna yang sama dengan kata memancing yang bermakna mengail ikan.

\section{F. RANGKUMAN}

a. Kalimat merupakan satuan sintaksis yang tersusun atas konstituen dasar berupa klausa dan dilengkapi dengan konjungsi, serta disertai dengan intonasi akhir.

b. Kalimat inti atau kalimat dasar merupakan kalimat yang terbentuk dari klausa inti lengkap. Klausa inti tersebut bisa bersifat deklaratif, aktif, serta afirmatif

c. Kalimat non inti merupakan kalimat yang terjadi karena adanya proses transformasi dari kalimat inti.

d. Berdasarkan jumlah klausanya, kalimat dibedakan mejadi dua jenis, yaitu kalimat tunggal dan kalimat majemuk.

e. Kalimat tunggal merupakan kalimat yang terdiri dari satu klausa.

f. Kalimat majemuk yaitu kalimat yang terdiri dari dua klausa atau lebih.

g.Kalimat majemuk dibagi menjadi tiga jenis, yaitu kalimat majemuk setara, kalimat majemuk bertingkat, dan kalimat majemuk campuran.

h.Berdasarkan sifat hubungan antar klausa dalam kalimat, kalimat majemuk campuran menjadi beberapa jenis, yaitu 
kalimat majemuk koordinatif (kalimat majemuk setara), kalimat majemuk subordinatif (kalimat majemuk bertingkat), serta kalimat majemuk kompleks.

i. Kalimat majemuk koordinatif yaitu kalimat majemuk yang terdiri dari beberapa klausa yang memiliki status yang sama atau setara.

j. Kalimat majemuk bertingkat (subordinatif) yaitu kalimat yang terdiri dari beberapa klausa yang tidak setara yaitu klausa utama (induk kalimat) dan klausa bawahan (anak kalimat).

k. Kalimat majemuk kompleks yaitu kalimat yang terdiri dari tiga klausa atau lebih yang mana bias dihubungkan secara koordinatif maupun subordinatif.

1. Kalimat mayor yaitu kalimat yang memiliki klausa lengkap, yaitu sekurang-kurangnya memiliki unsur subjek dan predikat.

m. Kalimat minor yaitu kalimat yang memiliki klausa tidak lengkap (hanya terdiri dari subjek saja, predikat saja, objek saja, atau keterangan saja).

n.Kalimat transitif yaitu kalimat yang memiliki predikat berupa kata kerja transitif dan biasanya diikuti oleh objek.

o.Kalimat intransitif yaitu kalimat yang memiliki predikat berupa kata kerja intransitive dan tidak memiliki objek.

p.Kalimat aktif yaitu kalimat yang subjeknya berperan sebagai pelaku secara aktif.

q.Kalimat pasif yaitu kalimat yang subjeknya dikenai pekerjaan.

r. Kalimat dinamis yaitu kalimat yang secara semantik (makna) predikatnya menyatakan suatu tindakan. 
s. Kalimat statis merupakan kebalikan dari kalimat dinamis yaitu secara semantis predikatnya menyatakan tindakan.

t. Kalimat reflektif yaitu kalimat yang subjeknya menjadi pelaku dan sekaligus menjadi penderita.

u.Makna leksikal merupakan makna yang dimiliki sebuah leksem tanpa ada konteks apapun.

v.Makna gramatikal merupakan makna yang terbentuk karena adanya proses gramatikal yaitu berupa afiksasi, reduplikasi, maupun komposisi.

w. Makna kontekstual yaitu makna yang muncul berdasarkan konteks tertentu.

x.Makna idiom merupakan makna yang terdiri dari beberapa unsur bahasa yang biasanya terbentuk dari gabungan kata atau frasa, dan maknanya tidak bisa diterangkan secara leksikal atau makna gramatikal.

y. Jenis pergeseran makna diantaranya: generalisasi, spesialisasi, sinestesia, ameliorasi, peyorasi, dan asosiasi.

\section{G.SOAL EVALUASI!}

1. Diskusikan dengan teman sekelompokmu mengenai perbedaan frasa, klausa dan kalimat!

2. Sebutkan jenis-jenis kalimat, dan berikan masing-masing 5 contoh kalimat tersebut!

3. Jelaslan beberapa pola atau struktur kalimat inti dan berikan masing-masing contohnya!

4. Sebutkan jenis-jenis kalimat tunggal dan berikan masingmasing contohnya!

5. Jelaskan perbedaan kalimat majemuk koordinatif dan kalimat majemuk subordinatif!

6. Buatlah 5 contoh kalimat majemuk kompleks (campuran)! 
7. Sebutkan jenis-jenis kalimat verbal! Berikan masingmasing contohnya!

8. Jelaskan perbedaan antara makna leksikal, gramatikal, dan kontekstual! Berikan masing-masing contohnya!

9. Jelaskan perbedaan antara makna referensi dan non referensi! Berikan masing-masing contohnya!

10. Berikan masing-masing 5 contoh dari makna denotatif dan makna konotatif!

11. Jelaskan perbedaan antara homofon dan homograf! Berikan masing-masing contohnya!

12. Buatlah 5 contoh kalimat yang mengandung makna redundansi!

13. Berikan masing-masing 3 contoh pergeseran makna generalisasi, spesialisasi, sinestesia, ameliorasi, peyorasi, dan asosiasi! 


\section{BAB VI \\ PARAGRAF}

\section{Tujuan Instruksional}

Mahasiswa mampu mengetahui definisi paragraf, ciri dan komponen paragraf, jenis paragraf, dan pengembangan paragraf

\section{A. PENGERTIAN PARAGRAF}

Paragraf merupakan suatu satuan pikiran yang terkecil dalam suatu karangan. Menurut Widjono (2007) bahwa paragraf merupakan bagian dari sebuah karangan yang terdiri dari beberapa kalimat yang tersusun secara runtut, logis dalam satu kesatuan ide yang tersusun secara utuh dan padu. Paragraf mengemukakan sebuah pokok pikiran atau satu gagasan utama yang disampaikan dalam himpunan kalimat yang koherensif. Paragraf bisa terdiri dari dua kalimat, tiga kalimat, empat kalimat, bahkan terdiri dari puluhan kalimat. Paragraf yang hanya terdiri dari dua kalimat dinamakan paragraf kurus, sedangkan paragraf yang terdiri dari puluhan kalimat disebut dengan paragraf gemuk. Paragraf yang terdiri dari dua kalimat memuat informasi yang sangat terbatas, ide pokok yang dirumuskan dalam satu kalimat topik hanya dijelaskan oleh satu kalimat penjelas saja. Hal ini akan menjadikan paragraf tersebut kurang bisa dipahami oleh pembaca. Sebaliknya, paragraf yang terdiri darsi berpuluhpuluh kalimat akan menyulitkan pembaca untuk menemukan ide pokok dari suatu paragraf. Biasanya, paragraf yang terdiri dari puluhan kalimat akan menyampaikan informasi yang sampai pada hal-hal yang kecil bahkan informasi yang kurang 
penting, sehingga ada kecenderungan menyimpang dari ide pokok. Dalam menulis sebuah karangan, paragraf gemuk hendaknya dihindari supaya ide yang diungkapkan bisa menjadi lebih jelas dan lebih fokus. Jika memungkinkan, paragraf yang gemuk bisa dipecah menjadi dua buah paragraf sehingga apa yang disampaikan dalam sebuah tulisan mudan dipahami oleh pembaca.

\section{B. CIRI DAN KOMPONEN PARAGRAF}

Dalam suatu tulisan misalnya buku atau artikel mengandung gagasan yang begitu luas. Ide tersebut tidak mungkin disajikan secara utuh, ide tersebut akan dipecah menjadi beberapa ide yang lebih kecil atau lebih spesifik dalam bentuk paragraf. Dalam suatu paragraf berisi satu ide pokok yang merupakan bagian dari ide yang lebih besar atau disebut dengan tema. Ide pokok tersebut dikembangkan dan dituangkan dalam beberapa kalimat, kalimat-kalimat tersebut tetap bertumpu pada ide pokoknya.

Widjono (2007) menjelaskan bahwa sebuah paragraf memiliki ciri-ciri sebagai berikut:

a. Kalimat pertama menjorok kedalam (indented) kurang lebih lima ketukan spasi. Jenis tulisan yang menggunakan ketukan lima spasi misalnya karangan biasa, dan juga surat. Sedangkan untuk jenis tulisan ilmiah formal misalnya makalah, skripsi, tesis, dan disertasi menggunakan delapan ketukan.

b. Paragraf memiliki pikiran utama yang dituliskan dalam sebuah kalimat topik

c. Paragraf memiliki kalimat-kalimat penjelas yang berfungsi untuk menjelaskan kalimat topik 
Paragraf yang baik harus memenuhi syarat diantaranya kesatuan, kepaduan, ketuntasan, dan konsistensi sudut pandang (Widjono, 2007). Selain itu, paragraf yang baik harus terdiri dari tiga unsur, yaitu kalimat topik (topic sentence), kalimat penjelas (supporting sentences / supporting details), dan juga kalimat penutup (concluding sentence) (Brent, 1980). Dalam satu paragraf hanya terdiri dari satu kalimat topik, sedangkan kalimat topik terdiri dari topik dan juga pembatas (controlling idea). Topik merupakan kata atau frasa kunci yang berisi pokok pembicaraan yang dikembangkan dalam suatu paragraf. Biasanya topik mencakup masalah yang cukup luas, oleh karena itu topik perlu dibatasi. Dalam suatu paragraf, pembatas berfungsi untuk mempersempit cakupan sebuah topik.

Kalimat topik hendaknya dirumuskan dengan menggunakan kalimat efektif, agar kalimat tersebut mudah dipahami pembaca. Kalimat topik harus dirumuskan secara jelas, lengkap, dan juga memenuhi unsur gramatikal atau memenuhi kaidah-kaidah ketatabahasaan yang berlaku. Kalimat topik yang baik akan mempermudah dalam mencari ide penjelas. Selain itu paragraf juga terdiri dari beberapa kalimat penjelas. Kalimat penjelas berfungsi untuk memberikan penjelasan yang merujuk pada kalimat topik. Kalimat kalimat penjelas hendaknya memberikan keterangan tambahan yang baru dan memberikan informasi atau keterangan-keterangan secara lengkap sehingga paragraf mudah dipahami oleh pembaca. Kalimat penjelas juga bisa berupa contoh-contoh, ilustrasi, bukti-bukti, alasan, perincian 
statistik, bahkan bisa berupa gambar yang tetap merujuk pada kalimat topik.

Hubungan antara kalimat topik dan juga kalimat penjelas dapat digambarkan sebagai berikut:

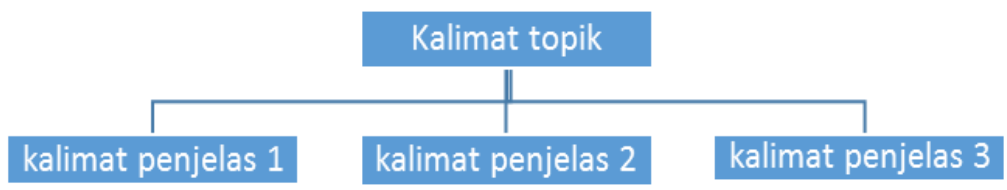

Berikut merupakan beberapa contoh kalimat topik :

- Kaliwatu merupakan salah satu destinasi wisata yang menarik di Malang.

- Merokok dapat membahayakan kesehatan.

- Kolestrol dapat memicu timbulnya penyakit yang membahayakan.

- Kadar asam yang tinggi sangat berbahaya bagi kehidupan dan lingkungan.

Sebagaimana dijelaskan di atas bahwa paragraf yang baik harus memenuhi prinsip keutuhan (unity) dan juga kepaduan (coherence). Keutuhan merupakan syarat utama dalam penulisan sebuah paragraf. Sebuah paragraf dikatakan utuh apabila kalimat-kalimat penjelas yang dikemukakan mengacu pada kalimat topik atau ide pokok paragraf (Masithoh, 2005). Dengan kata lain, apabila kalimat-kalimat penjelas yang diungkapkan tidak relevan dengan kalimat topik, maka suatau paragraf dikatakan tidak utuh. Sedangkan prinsip kepaduan berati kalimat yang dikembangkan dalam suatu paragraf saling terkait. Untuk menunjukkan adanya koherensi dalam 
suatu paragraf dapat mengguankan penanda kohesi yang sesuai. Adapun maksud dari kohesi yaitu penanda adanya hubungan antar bagian dalam suatu karangan, misalnya kata penghubung karena itu, oleh sebab itu, dengan demikian, dan sebagainya. Dengan adanya kohesi ini, suatu paragraf akan tampak sempurna dan lebih enak dibaca. Paragraf yang baik juga harus tersusun secara runtut atau teratur. Kalimat satu dengan kalimat yang lain harus saling berhubungan. Syarat lain yang harus dipenuhi dalam menulis paragraf adalah kelengkapan (completetness). Kalimat topik yang mengandung ide pokok harus dikembangkan dan dijelaskan agar dapat terbentuk sebuah paragraf. Pengembangan tersebut harus diungkapkan secara lengkap agar pembaca bisa memahami paragraf secara komprehensif.

\section{JENIS PARAGRAF}

Dalam sebuah karangan terdapat berbagai macam jenis paragraf. Menurut fungsinya, paragraf terdiri dari dua bagian yaitu, paragraf pengantar dan paragraf pengembang (Widjono, 2007). Fungsi dari paragraf pengantar yaitu untuk memberitahukan latar belakang serta menunjukkan pokok persoalan yang akan dibahas dalam suatu paragraf. Sedangkan paragraf pengembang berfungsi untuk menjelaskan atau menguraikan gagasan pokok dalam sebuah karangan. Paragraf pengembang bisa berisi tentang konsep, alasan, pembuktian, argumen, contoh-contoh, fakta, rincian yang berhubungan dengan ide pokok suatu paragraf.

Jika dilihat dari sudut pandang tujuan sebuah karangan, maka paragraf terbagi menjadi beberapa jenis, yaitu (a) 
Paragraf eksposisi, (b) Paragraf argumentasi, (c) Paragraf deskripsi, (d) Paragraf narasi, dan (e) Paragraf persuasi.

\section{a. Paragraf eksposisi}

Suratno (2010) menjelaskan bahwa paragraf eksposisi merupakan bentuk paragraf yang menerangkan dan menguraikan suatu pokok pikiran sehingga mampu memperluas pengetahuan pembaca yang dilengkapi dengan data, fakta, serta analisis. Paragraf eksposisi memiliki ciri yang bersifat informatif, serta diserta fakta atau data yang dapat mendukung informasi supaya lebih akurat. Contoh paragraf eksposisi:

Jambu biji memiliki banyak manfaat bagi kesehatan. Beberapa kandungan penting di dalam jambu biji seperti mineral dan vitamin mampu menyehatkan tubuh kita. Bahkan jambu biji memiliki kandungan vitamin $\mathrm{C}$ yang tinggi sehingga mampu mencegah tubuh kita dari berbagai penyakit. Selain itu, kandungan lycopene di dalam jambu biji bermanfaat sebagai zat anti-inflamasi dan mencegah pertumbuhan tumor.

\section{b. Paragraf argumentasi}

Paragraf argumentasi merupakan jenis paragraf yang mengungkapkan suatu gagasan atau sikap dan disertai dengan alasan sehingga pembaca mampu memahami dan meyakini kebenaran yang disampaikan penulis (Akhadiah, 1997). Contoh paragraf argumentasi:

Kasus kenakalan remaja saat ini menjadi sangat mengkhawatirkan. Makin banyaknya kasus kehamilan usia 
remaja dan penggunaan obat-obatan menjadi salah satu bukti kongkrit adanya degradasi moral. Hal tersebut hampir terjadi pada remaja usia sekolah. Kurangnya pengawasan orang tua menjadi salah satu penyebab terjadinya kenakalan remaja. Selain itu, pengaruh lingkungan, teman, dan kurangnya pemahaman tentang agama juga menjadi pemicu kenakalan remaja. Oleh karena itu, perlu adanya bimbingan khusus dan kerjasama antar pihak sekolah dan orang tua agar terjadi sinergi dalam menanggulangi adanya kenakalan remaja.

\section{c. Paragraf deskripsi}

Paragraf deskripsi meripakan paragraf yang berisi tentang penggambaran suatu objek, benda, tempat, maupun peristiwa tertentu secara jelas dan terperinci sehinggga pembaca seolaholah melihat dan merasakan sendiri apa yang dideskripsikan oleh penulis. Contoh paragaraf deskripsi:

Pantai Parangtritis merupakan salah satu objek wisata yang digemari di Daerah Istimewa Yogyakarta. Banyak pengunjung yang berdatangan karena keelokan pantai ini. Pantai Parangtritis memiliki ombak yang besar. Ombak pantai dapat mencapai ketinggian $2-3$ meter pada musim kemarau. Terdapat gunung-gunung pasir di sekitar kawasan pantai. Gunung-gunung pasir ini lebih dikenal dengan nama gumuk. Di pinggir pantai disediakan payung-payung besar yang dapat digunakan pengunjung untuk beristirahat sambil menikmati pemandangan. Selain itu terdapat wisata naik kuda, dokar, ataupun motor ATV di sepanjang pinggir pantai. 


\section{d. Paragraf narasi}

Paragaraf narasi merupakan paragraf yang menyajikan serangkaian peristiwa atau kejadian menurut uraian terjadinya ( kronologi) sehingga pembaca dapat memetik hikmah dari cerita itu. (Suparno, 2007). Umumnya paragraf narasi digunakan untuk menceritakan sebuah karangan fiksi. Contoh paragraf narasi:

Pada saat libur Hari Raya, kami sekeluarga pergi ke rumah paman yang ada di Malang. Perjalanan kami kurang lebih menghabiskan waktu selama tiga jam. Sepanjang perjalanan kami menikmati pemandangan yang indah, jalan yang berkelok-kelok, serta sungai yang dialiri air yang begitu jernih. Semua tampak menyejukkan mata. Sekali waktu kami menghampiri warung kopi yang terletak di sekitar bendungan Karangkates sambil menikmati indahnya pemandangan sekitar. Tidak lupa kami mengabadikan momen indah tersebut dengan kamera ponsel yang kami bawa. Setelah istirahat sejenak, kami melanjutkan perjalanan agar cepat sampai di rumah paman. Selang beberapa waktu kami tiba di rumah paman di kota Malang. Rumah paman yang mewah dan sejuk membuat kami merasa nyaman. Sesampai di sana kami membersihkan badan lalu menghabiskan waktu bersama keluarga paman. Perjalanan kali ini sungguh menyenangkan dan menjadi kenangan yang tidak akan pernah kami lupakan.

\section{D.PENGEMBANGAN PARAGRAF}

Sebagaimana dijelaskan sebelumnya bahwa paragraf terdiri dari kalimat topik dan juga kalimat penjelas. Dalam 
mengembangkan suatu paragraf diperlukan topik yang tidak terlalu luas (umum) dan juga tidak terlalu sempit (khusus). Pemilihan topik yang terlalu sempit akan menyulitkan penulis untuk mencari dan mengembangkan ide penjelas. Sebaliknya, topik yang terlalu umum tidak akan cukup jika dikembangkan dalam satu paragraf. Untuk memilih topik dalam suatu paragraf hendaknya memperhatikan panjang pendek suatu paragraf. Topik yang cocok untuk paragraf biasanya dapat dikembangkan dengan menggunakan kurang lebih 150 kata agar topik bisa dijelaskan secara tuntas dan memudahkan pembaca dalam memahami suatu paragraf. Topik yang cocok untuk dituliskan dalam suatu paragraf seharusnya topik yang cakupannya idenya dapat dibatasi (controlling idea). Salah satu usaha agar menghasilkan tulisan yang baik maka penulis harus memilih topik yang baik. Topik yang baik bisa membantu meningkatkan kualitas tulisan. Pemilihan topik dalam suatu paragraf hendaknya memperhatikan kriteria sebagai berikut:

a. Pilih pokok permasalahan yang paling menarik perhatian

Pemilihan topik yang menarik akan merangsang penulis untuk mencari bahan-bahan yang relevan. Dengan rasa tertarik terhadap permasalahan atau topik yang diangkat maka keterlibatan penulis sangat tinggi sehingga sangat membantu keberhasilan penulisan tersebut.

b. Pilih pokok permasalahan yang paling dekat dan paling dikuasai

Permasalahan yang diambil hendaknya yang familiar dengan penulis, pokok permasalahan yang diambil berada dalam jangkauan kemampuan penulis. Jika 
pokok permasalahan atau topik yang diambil kurang dikuasai dan berada diluar jangkauan penulis akan menyulitkan penulis dalam mengembangkan paragraf.

c. Pilih pokok permasalahan yang memiliki fakta dan data objektif

Pemilihan pokok permasalahan yang objektif dan sesuai dengan fakta akan memudahkan penulis untuk mengembangkan sebuah paragraf, karena jika permasalahan yang tidak sesuai dengan fakta ilmiah akan menyeret penuis pada permasalahan yang sbstrak dan fiktif.

d. Pilih pokok permasalahan yang spesifik

Pokok permasalahan yang terlalu luas akan menyulitkan penulis dalam mengembangkan sebuah paragraf. Semakin luas permasalahan yang dibahas dalam suatu tulisan, maka semakin besar kemungkinan kesulitan yang dihadapi penulis. Permasalahan yang terlalu luas cenderung membawa penulis pada pembahasan yang tidak terarah dan dangkal.

e. Pilih pokok permasalahan yang diketahui prinsipprinsip dan tata kerjanya

Penulis hendaknya memilih topik yang sudah diketahui prinsip-prinsip ilmiah dan cara kerjanya. Penulis hendaknya tidak mengambil pokok permasalahan yang sama sekali baru baginya

f. Pilih pokok permasalahan yang mudah ditemukan sumber-sumber acuannya

Sumber- sumber acuan sangat bermanfaat bagi penulis dalam mengembangkan sebuah pokok permasalahan yang akan ditulis. Semakin banyak sumber acuan yang 
dimiliki oleh penulis, semakin besar pula kemungkinan penulis mendalami pokok permasalahan yang dibahas.

g. Pilih pokok permasalahan yang bermanfaat dan layak dibahas

Permasalaha yang diambil hendanya yang mampu memberikan manfaat bagi pembaca. Pemilihan topik permasalahan yang telah banyak dikuasai oleh orang sebaiknya dihindari karena bisa menimbulkan rasa bosan bagi pembaca.

h. Pilih pokok permasalahan yang tidak bertentangan dengan etika dan moral

Permasalahan yang bertentangan dengan etika dan moral sebaiknya dihindari karena justru akan menimbulkan permasalahan bahkan tidak diterima oleh pembaca.

i. Pilih permasalahan yang merangsang minat baca bagi penulis maupun pembaca.

Pemilihan topik yang mampu merangsang minat baca penulis akana menimbulkan dampak positif diantaranya penulis akan mengakaji permasalahan tersebut sedalamdalamnya. Sedangkan dampak positif bagi pembaca diantaranya pembaca akan membaca secara cermat, kritis, dan sungguh-sungguh.

Dalam pengembangan suatu paragraf, diperlukan cara untuk menyusun kalimat topik. Kalimat topik berguna untuk mengikat kesatuan makna dalam suatu paragraf. Kalimat topik berfungsi untuk menyatukan beberapa kalimat penjelas yang dikembangkan dalam suatu paragraf, sehingga makna kalimat penjelas dapat fokus dalam satu ide. Ada beberapa cara untuk menempatkan kalimat topik dalam sebuah 
paragraf, yaitu di awal paragraf, di tengah paragraf, di akhir paragraf, serta di awal dan di akhir paragraf. Peletakan kalimat topik di awal paragraf dapat mempermudah pembaca dalam menemukan ide pokok suatu paragraf dan sangat membantu dalam proses membaca jenis skimming, skipping , dan juga scanning. Sedangkan peletakan kalimat topik di tengah paragraf secara teoritis dimungkinkan akan tetapi jarang dilakukan dalam kegiatan tulis menulis. Kalimat topik yang terletak di awal paragraf disebut sebagai paragraf deduktif, jika terletak di akhir paragraf disebut sebagai paragraf induktif, sedangkan jika terletak di awal dan akhir paragraf disebut sebagai paragraf deduktif-induktif.

Dalam mengembangkan suatu paragraf diperlukan kalimat-kalimat penjelas untuk mengembangkan ide pokok dalam suatu paragraf. Adapun fungsi dari kalimat penjelas adalah sebagai berikut:

a.Memberikan ide tambahan yang dapat mendukung, menjelaskan, dan menunjang kalimat topik.

b.Menerangkan kalimat topik. Kalimat topik biasanya masih bersifat umum maka perlu penjelasan yang dituangkan dalam kalimat penjelas.

c.Meyakinkan pembaca terhadap ide pokok yang disampaikan.

d.Memberikan gambaran atmosfer atau suasana dalam suatu tulisan.

Kalimat penjelas hendaknya disusun secara logis dan relevan dengan kalimat topik. Untuk memilih sebuah kalimat penjelas yang bagus maka perlu memperhatikan kriteria sebagai berikut: 
a. Adekuat, artinya kalimat penjelas yang dipilih harus tepat sesuai dengan kalimat topik.

b. Sigifikan, artinya kalimat penjelas yang digunakan hanya kalimat yang benar-benar relevan dengan kalimat topik dan juga penting.

c. Kecukupan, artinya jumlah kalimat topik yang ditulis tidak kurang dan tidak lebih.

d. Lengkap, artinya semua masalah dalam kalimat topik telah dijelaskan.

e. Baru, artinya semua penjelas mempunyai ide tambahan yang tidak tercantum dalam kalimat topik.

Untuk menghasilkan suatu paragraf yang berkualitas hendaknya diorganisasikan dengan baik. Sebelum memulai menulis, perlu membuat rancangan sebuah tulisan (outline) atau disebut juga sebagai kerangka karangan. Kerangka karangan memuat garis-garis besar dari suatu tulisan yang akan disusun, yang meliputi rencana kerja dan ketentuan tentang bagaimana sebuah tulisan tersebut akan disusun. Kerangka karangan yang baik memuat satu ide dalam sebuah pembahasan, sehingga penulis akan lebih mudah dalam mencari dan menentukan materi penujangnya. Selain itu pokok-pokok pikiran yang dimuat dalam outline harus tersusun dengan baik, logis, dan kronologis. Kerangka karangan juga harus memperhatikan prinsip kesejajaran, dalam artian pokok-pokok pembahasan dan sub babnya hendaknya dinyatakan dalam pernyataan yang seragam. Secara umum penyusunan kerangka karangan dapat membantu penulis menghindari kesalahan-kesalahan yang dapat terjadi saat menulis sebuah karangan. Pembuatan 
kerangka karangan memberikan beberapa manfaat bagi penulis, diantaranya:

a. Membantu melihat gagasan-gagasan secara global sehingga dapat diketahui hubungan timbal balik antar gagasan, kerincian, keharmonisan dan keseimbangan antara gagasan satu dengan gagasan lainnya.

b. Memudahkan penulis menciptakan klimaks yang berbeda-beda. Agar sebuah tulisan menghasilkan klimaks maka ide-ide yang disampaikan harus ditata sedemikian rupa.

c. Menghindari pengulangan pembahasan. Sering kali penulis tidak sengaja membahas suatu topik sampai beberapa kali sehingga menimbulkan rasa bosan terhadap pembaca. Selain itu, pembahasan yang dibahas lebih dari satu kali bisa menimbulkan kontradiksi antar ide.

d. Memudahkan penulis mencari bahan pendukung. Dengan membuat rincian topik yang telah tertata akan memudahkan penulis dalam mencari bahan yang akan dipakai untuk mengembangkan sebuah tulisan.

Untuk menyusun sebuah paragraf yang bagus perlu diperhatikan tahapan sebagai berikut:

1. Membuat outline

Pada tahap ini penulis perlu menentukan topik yang akan dituliskan dalam suatu paragraf dan mengumpulkan informasi-informasi pendukung

2. Menuliskan kalimat topik

3. Menyusun kalimat-kalimat penjelas yang mendukung kalimat topik 
4. Membuat kalimat penutup (concluding sentence). Kalimat penutup ini berfungsi untuk menegaskan kembali ide yang dibahas dalam kalimat topik.

5. Proses editing. Editing ini mencakup penulisan, tata bahasa, penggunaan tanda baca dan juga penggunaan ejaan.

\section{E. RANGKUMAN}

a. Paragraf merupakan bagian dari sebuah karangan yang terdiri dari beberapa kalimat yang tersusun secara runtut, logis dalam satu kesatuan ide yang tersusun secara utuh dan padu.

b. Paragraf memiliki ciri-ciri sebagai berikut:

- Kalimat pertama menjorok kedalam (indented) kurang lebih lima ketukan spasi.

- Paragraf memiliki pikiran utama yang dituliskan dalam sebuah kalimat topik.

- Paragraf memiliki kalimat-kalimat penjelas yang berfungsi untuk menjelaskan kalimat topik.

c.Paragraf eksposisi merupakan bentuk paragraf yang menerangkan dan menguraikan suatu pokok pikiran sehingga mampu memperluas pengetahuan pembaca yang dilengkapi dengan data, fakta, serta analisis.

d. Paragraf argumentasi merupakan jenis paragraf yang mengungkapkan suatu gagasan atau sikap dan disertai dengan alasan sehingga pembaca mampu memahami dan meyakini kebenaran yang disampaikan penulis.

e. Paragraf deskripsi meripakan paragraf yang berisi tentang penggambaran suatu objek, benda, tempat, maupun peristiwa tertentu secara jelas dan terperinci sehinggga 
pembaca seolah-olah melihat dan merasakan sendiri apa yang dideskripsikan oleh penulis.

f. Paragaraf narasi merupakan paragraf yang menyajikan serangkaian peristiwa atau kejadian menurut uraian terjadinya ( kronologi) sehingga pembaca dapat memetik hikmah dari cerita itu.

g. Kalimat penjelas memiliki beberapa fungsi sebagai berikut:

- Memberikan ide tambahan yang dapat mendukung, menjelaskan, dan menunjang kalimat topik.

- Menerangkan kalimat topik. Kalimat topik biasanya masih bersifat umum maka perlu penjelasan yang dituangkan dalam kalimat penjelas.

- Meyakinkan pembaca terhadap ide pokok yang disampaikan.

- Memberikan gambaran atmosfer atau suasana dalam suatu tulisan.

h.Untuk menyusun sebuah paragraf yang bagus perlu diperhatikan tahapan sebagai berikut:

- Membuat outline

- Menuliskan kalimat topik

- Menyusun kalimat-kalimat penjelas yang mendukung kalimat topik

- Membuat kalimat penutup (concluding sentence)

- Proses editing

\section{F. BAHAN DISKUSI}

1. Diskusikan dengan teman sekelompokmu mengenai ciri dan jenis paragraf!

2. Tulislah 5 contoh kalimat topik! 
3. Jelaskan mengenai perbedaan antara paragraf argumentasi dan paragraf eksposisi!

4. Jelaskan mengenai beberapa manfaat membuat kerangka karangan!

5. Buatlah masing-masing 1 contoh paragraf narasi, deskripsi, argumentasi, dan eksposisi! 


\section{BAB VII}

\section{SEJARAH DAN PERIODISASI SASTRA INDONESIA}

\section{Tujuan Instruksional}

Mampu memahami sejarah dan periodisasi sastra Indonesia, jenis sastra Indonesia

\section{A. PENGERTIAN SASTRA}

Pada dasarnya, sastra memiliki banyak pengertian, sebagaimana dikemukakan oleh beberapa ahli misalnya Sumardjo \& Saini (1997) yang menyatakan bahwa sastra merupakan suatu ungkapan pribadi manusia berupa pengalaman, pemikiran, perasaan, ide, serta keyakinan yang mampu membangkitkan pesona dengan alat bahasa. Wallek dan Werren (1995) berpendapat bahwa karya sastra merupakan karya imajinatif yang dipandang memiliki pengertian yang lebih luas dibandingkan karya fiksi. Sedangkan pengertian sastra Indonesia merupakan sastra yang berbahasa Indonesia, sedangkan hasilnya berupa puisi, cerpen, novel, roman, serta naskah drama berbahasa Indonesia (Yudiono, 2007). Pendapat lain juga mengatakan bahwa istilah sastra Indonesia berarti sastra (kesusastraan) berbahasa Indonesia yang lahir atau tumbuh sejak awal abad ke 20 dan selanjutnya berkembang marak bersama sastra daerah. Semi (1992) mengatakan, bahwa karya sastra merupakan hasil kreativitas pengarang yang menggunakan manusia dan segala macam segi kehidupannya sebagai objek kajiannya.Sastra meliputi segala bentuk dan macam tulisan yang ditulis oleh manusia, seperti catatan ilmu pengetahuan, kitab-kitab suci, surat-surat, dan sebagainya. Karya sastra bisa 
berbentuk lisan maupun tulisan. Kedua bentuk tersebut memiliki kekhasan pada keindahan bahasanya. Kosasih (2008) menjelaskan bahwa sastra memiliki ciri khas yaitu menggunakan bahasa yang indah, tertata dengan baik yang dilukiskan oleh para sastrawan sehingga menimbulkan ketertarikan bagi para pembacanya. Selain itu, sastra bersifat imajinatif,yang berasal dari hasil renungan, khayaan, maupun perasaan yang diwujudkan dalam kata-kata yang indah. Zulela (2012) juga memberikan penjelasan bahwa sastra merupakan salah satu kebutuhan manusia. Sastra merupakan bagian dari seni yang dapat memberikan kesenangan, hiburan, serta kebahagiaan kepada manusia. Selain itu karya sastra mampu menjadikan para pembaca lebih kaya akan pengetahuan serta pengalaman.

\section{B. FUNGSI SASTRA}

Sebagaimana dijelaskan di atas bahwa sastra merupakan sebagian kecil dari kebutuhan hidup. Sastra memiliki fungsi dalam kehidupan. Sebagaimana dijelaskan oleh Kosasih (2008) bahwa sastra memiliki dua fungsi yaitu:

\section{Fungsi Rekreatif (Delectare)}

Sastra merupakan seni yang mampu memberikan kesenangan atau hiburan kepada pembaca. Berbagai macam kehidupan disajikan oleh pengarang melalui cerita yang dituliskan dalam karya sastra. Dengan menikmati karya sastra, seseorang akan merasa terhibur, puas, dan memperoleh pengalaman batin tentang kehidupan manusia yang disajikan oleh pengarang. 


\section{Fungsi Didaktif (Decore)}

Fungsi sastra tidak hanya semata-mata menghibur, akan tetapi mampu memberikan pengetahuan tentang seluk beluk kehidupan dan memberikan pelajaran tentang nilainilai kebenaran. Masing-masing karya sastra memiliki kandungan fungsi yang berbeda. Ada karya sastra yang lbih condong pada aspek hiburan yang biasa disebut sebagai karya sastra popular. Sedangkan karya sastra yang lebih condong pada nilai didaktis disebut sebagai sastra serius (Kosasih, 2008).

\section{SEJARAH SASTRA INDONESIA}

Sejarah sastra merupakan cabang ilmu sastra yang mempelajari pertumbuhan dan perkembangan sastra suatu bangsa. Adapun objek kajian sastra yaitu segala peristiwa yang terjadi pada rentang masa pertumbuhan dan perkembangan sastra suatu bangsa. Sejarah sastra bisa menyangkut karya sastra, pengarang, penerbit, pengajaran, serta kritik sastra. Luxemburg (1982) menjelaskan bahwa dalam sejarah sastra dibahas periode-periode kesusastraan aliran, jenis, pengarang, serta reaksi pembaca.

Menurut Rosidi (1969) secara singkat sejarah sastra Indonesia dapat diringkas sebagai berikut. Pada abad ke-16 dan ke -17 perkenalan masyarakat Nusantara dengan bangsa Portugis, Belanda, serta Inggris telah mengubah nasib masyarakat Indonesia dari bangsa merdeka menjadi bangsa jajahan Belanda selama beratus-ratus tahun. Pada awal abad ke -20 politik Belanda yang awalnya sangat keras dan dengan berbagai cara ingin menguntungkan kepentingan mereka, 
pada akhirnya mulai melunak dengan melaksanakan politik etis. Adapun tujuan politik etis ini yaitu agar bangsa Indonesia merasa dekat dengan bangsa Belanda. Oleh karena itu mulailah dibuka beberapa sekolah untuk anak bumi putera yang memuat pelajaran tentang tata cara kehidupan, ilmu bumi negeri Belanda, pengetahuan umum, moral, dan bahasa Belanda. Usaha yang dilakukan Belanda tersebut membuat para pemimpin Indonesia giat memperjuangkan bahasa Melayu sebagai bahasa persatuan nasional sehingga tercetus Sumpah Pemuda. Sejak saat itu, para tokoh yang terrkeanal misalnya Ki Hajar Dewantara, Abdul Muis, dan yang lainnya yang awalnya terbiasa menggunakan bahasa Belanda dalam menulis dan berpidato, mulai beralih menggunakan Bahasa Indonesia. Pada zaman penjajahan Belanda abad ke-19 belum ada bahasa Indonesia, yang berkembang adalah bahasa daerah sehingga dengan sendirinya sastra yang berkembang pun berasal dari berbagai bahasa daerah itu. Diantara beberapa bahasa daerah bahasa Jawa, Sunda dan Melayu merupakan bahasa yang berperan penting dalam perkembangan sastra.

\section{PERIODISASI SASTRA INDONESIA}

Pembagian zaman periodisasi sastra Indonesia modern sampai sekarang masih menjadi bahan perdebatan karena belum ada suatu pembabakan waktu yang diterima secara penuh oleh para ahli sastra. Menurut Kosasih (2008) dan Jassin (1981) secara garis besar karya sastra dibagi menjadi dua periode, yaitu sastra lama dan sastra baru (modern). Sastra lama disebut juga sastra klasik atau kesusastraan tradisional. Sastra lama berkembang sebelum masuknya pengaruh Barat ke Indonesia. Jenis karya sastra lama menurut 
Kosasih (2008) yaitu mantra, pantun, talibun, pantun kilat, gurindam, syair, peribahasa, teka-teki, fabel, legenda, dan hikayat. Kosasih (2008) juga menjelaskan bahwa karya sastra lama memiliki beberapa ciri, yaitu:

1. Nama pengarang tidak diketahui (anonim)

2. Cerita yang dsajikan banyak diwarnai oleh hal gaib (Pralogis)

3. Kata-kata yang digunakan banyak menggunakan bahasa baku, misalnya alkisah, konon, dan sebagainaya.

4. Cerita yang disajikan berupa kehidupan istana, dewa, pahlawan, dan sebagainya.

5. Berkembang secara lisan, karena belum ada media cetak atau elektronik.

Sedangkan sastra Indonesia modern merupakan karya sastra yang berkembang pada abad 20-an. Kosasih (2008) menjelaskan karya sastra pada masa ini memiliki beberapa ciri yaitu

1. Bertema tentang kehidupan masyarakat sehari-hari, misalnya mengenai adat, pekerjaan, persoalan rumah tangga, serta adat.

2. Mendapat pengaruh dari kesusastraan Barat. Hal ini bisa dilihat dari tema serta tokoh-tokoh dalam cerita.

3. Nama pengarangnya dinyatakan dengan jelas.

Rosidi (1969) membagi sejarah sastra Indonesia dalam beberapa periode, yaitu:

1. Masa Kelahiran atau masa kebangkitan yang mencakup kurun waktu tahun 1900 -1945 yang dapat dibagi lagi menjadi beberapa periode, yaitu: 
a. Periode awal hingga 1933

Persoalan yang mewarnai karya sastra di masa ini adalah mengenai adat yang sedang mengalami akulturasi sehingga menimbulkan berbagai masalah bagi kelangsungan eksistensi masing-masing.

b.Periode 1933 -1942

Pada masa ini karya sastra diwarnai oleh pencarian tempat di tengah pertarungan kebudayaan Timur dan Barat dengan pandangan romantis-idealis

c.Periode 1942- 1945

Pada masa ini bersamaan dengan masa kependudukan Jepang yang melahirkan warna pelarian, kegelisahan, serta peralihan.

2. Masa Perkembangan yaitu pada kurun waktu 1945-1968, kemudian dibagi menjadi beberapa periode, yaitu:

a.Periode 1945-1953

Pada masa ini karya sastra diwarnai oleh perjuangan dan pernyataan diri di tengah kebudayaan dunia.

b.Periode 1953-1961

Pada masa ini karya sastra diwarnai oleh pencarian identitas diri dan penilaian kembali terhadap warisan leluhur.

c.Periode 1961-1968

Pada masa ini karya sastra diwarnai oleh perlawanan dan memperjuangkan martabat.

Selain pendapat Rosidi tersebut, Kosasih (2008) menjelaskan bahwa karya sastra modern terdiri dari beberapa angkatan, yaitu Angkatan Balai Pustaka, Angkatan Pujangga 
Baru, Angkatan '45, angkatan '66, angkatan 70 an, angkatan 80 an, angkatan reformasi, dan angkatan 2000.

\section{a. Angkatan Balai Pustaka}

Angkatan Balai Pusataka menghasilkan beberapa karya sastra Indonesia sejak tahun 1920. Karya-karya tersebut dikeluarkan oleh penerbit Balai Pustaka. Pada masa ini terdapat dukungan dari kaum terpelajar yang semakin sadar pada kenyataan bahwa bangsa yang sedang terjajah. Kondisi sosial masyarakat yang berupa konflik, serta kondisi ekonomi dan politik mewarnai karya sastra pada zaman ini. Selain itu adanya permasalahan adat serta tradisi juga ikut mewarnai karya sastra pada zaman ini. Beberapa jenis prosa yaitu roman, novel, cerita pendek, drama, dan puisi pada tahun ini mulai menggantikan kedudukan syair, pantun, gurindam dan hikayat. Diantara jenis prosa tersebut, roman merupakan sastra yang utama pada zaman ini yang berkaitan dengan permasalahan adat kawin paksa, permaduan, pertentangan paham antara kaum muda dan kaum tua, berlatar daerah, pedesaan, serta belum mempersoalkan cita-cita kebangsaan. Sumardjo (dalam Yudiono, 2007) menjelaskan bahwa romanroman angkatan Balai Pustaka memiliki ciri umum, diantaranya:

(a) Bersifat kedaerahan, karena mengungkapkan persoalan yang berlaku di wilayah tertentu, khususnya di daerah Minangkabau,

(b) Bersifat romantic-sentimental, karena banyak roman yang mematikan tokoh cerita atau dengan kata lain tokoh mengalami penderitaan yang luar biasa, 
(c) Bergaya bahasa seragam karena dikelola oleh Balai Pustaka sehingga tidak ada gaya bahasa perorangan,

(d) Bertemakan sosial, karena pada saat itu belum ada kesempatan mempersoalkan masalah-masalah politik, agama, watak, dan sebagainya.

Sedangkan menurut Kosasih (2008) karya-karya yang diterbitkan oleh Balai Pustaka secara umum bertema tentang kehidupan sosial, misalnya kesetiaan istri kepada suami atau orang tua, kepatuhan kepada adat, hasrat dan pentingnya belajar, dan rasa sayang dan hormat kepada sesama manusia. Novel-novel yang terbit pada periode Balai Pustaka merupakan kelanjutan dari tradisi sastra romantic Barat yang masuk ke Indonesia, baik yang masuk melalui lembaga pendidikan maupun media masa (Faruk: 2002). Balai Pustaka menerbitkan karya satra dalam tiga bahasa yaitu bahasa Melayu-Tinggi, bahasa Jawa dan bahasa Sunda; dan dalam jumlah terbatas dalam bahasa Bali, bahasa Batak, dan bahasa Madura. Novel yang pertama kali terbit pada zaman ini adalah novel karya Merari Siregar yang berjudul Azab dan Sengsara. Sedangkan novel yang paling digemari pada masa ini adalah novel Siti Nurbaya karya Marah Rusli. Beberapa sastrawan yang terkenal pada Angkatan Balai Pustaka diantaranya:

1. Merari siregar, karya-karyanya : Azab dan Sengsara (novel, tahun 1920), serta Binasa kerna Gadis Priangan (1931)

2.Marah Roesli, karya-karyanya : Siti Nurbaya (1922), Laihami (1924), dan Anak dan Kemanakan (1956) 
3.Muhammad Yamin, karya-karyanya: Tanah Air (1922), Indonesia Tumpah Darahku (1928), Ken Arok dan Ken Dedes (1934)

4.Nur Sultan Iskandar, karya-karyanya: Apa Dayaku Karna Aku Perempuan (1922), Karena Mertua (1932), Katak Hendak Menjadi Lembu (1934), Cinta Yang Membawa Maut (1926), Salah Pilih (1928), Tuba Dibalas Dengan Susu (1933), Neraka Dunia (1937) dan Hulubalang Raja (1934).

5. Abdul Muis, karya-karyanya: Salah Asuhan (novel, tahun 1928) , Surapati (1950), Robert Anak Surapati (1953) dan Pertemuan Jodoh (1933)

6. Lulis Sutan Suti, karya-katyanya: Tak Disangka (1923), Sengsara Membawa Nikmat (1928), Tak Membalas Guna (1932), dan Memutuskan Pertalian (1932)

7. Djamaluddin Adinegoro, karya-karyanya: Dara Muda (1927), Asmara Jaya (1928), dan Pertemuan (1927)

8. Aman Datuk Madjoindo, karya-karyanya: Menebus Dosa (1932), Si Cebol Merindukan Bulan (1934), dan Sampaikan Salamku Kepadanya (1935)

b. Angkatan Pujangga Baru

Angkatan Pujangga Baru merupakan angkatan periode kedua yaitu sekitar tahun 1930-1940 an. Adapun ciri dari karya sastra pada angkatan ini yaitu mengenai persoalan masyaralat kota, masalah yang universal tentang hubungan manusia baik sebagai masyarakat maupun individu, persoalan intelektual, emansipasi, pengaruh barat yang mulai masuk dan berupaya melahirkan budaya nasional, serta menonjolkan semangat nasionalisme, romantisme, individualisme, 
intelektualisme, dan materialisme. Pada masa ini sudah tidak ada lagi intervensi masalah adat, tradisi, agama, serta moral. Pada masa Pujangga Baru, karya sastra berupa puisi sangatlah dominan dan cerita pendek serta drama mulai ditulis. Adapun karya sastra pada zaman ini pada umumnya beraliran romantik karena adanya pengaruh Gerakan 80 di Belanda.

Pada masa ini yaitu pada tahun 1933 terbit majalah Pujangga Baru yang dipimpin oleh Sutan Takdir Alisjahbana, beserta Amir Hamzah dan Armijn Pane. Adapun tujuan dari terbitnya majalah ini yaitu untuk menumbuhkan kesusastraan baru yang sesuai dengan semangat zamannya, serta untuk mempersatukan para sastrawan dalam satu wadah, karena sebelumnya para sastrawan cerai berai karena menulis diberbagai majalah. Sebenarnya usaha untuk menerbitkan suatu majalah kesusastraan sudah muncul pada tahun 1921, 1925, dan 1929 akan tetapi usaha tersebut selalu gagal (Yudiono, 2007). Terbitnya majalah Pujangga Baru mendapat sambutan yang hangat dari beberapa kaum terpelajar, akan tetapi banyak pula mendapat kritikan dari para guru yang setia kepada pemerintah Belanda, karena majalah tersebut memasukkan bahasa daerah dan bahasa asing sehingga merusak bahasa Melayu. Majalah Pujangga Baru terbit hingga tahun 1942, kemudian oleh penguasa militer Jepang, majalah tersebut dilarang untuk diterbitkan karena dianggap kebarat-baratan dan progresif (Yudiono, 2007). Majalah Pujangga Baru juga tidak mendapat tanggapan oleh kaum bangsa Melayu, bahkan pernah dikirimkan kepada para Sultan, akan tetapi tidak mendapat sambutan hangat. Selain itu peminat majalah Pujangga Baru hanya sedikit. Pada saat itu, yang tercetak paling banyak sebanyak 400 eksemplar 
yang tersebar hanya terbatas di kalangan guru karena mereka dianggap memiliki perhatian terhadap permasalahan kebudayaan dan kesusatraan. Permasalahan lain yang muncul yaitu majalah Pujangga Baru juga tidak didukung modal keuangan, bahkan tidak menyediakan honorarium untuk para redaksi, namun masalah tersebut tidak menjadi masalah bagi para penulis, terbukti banyak tulisan yang masuk ke redaksi Pujangga baru. Namun, pada tahun 1949-1953 (setelah Indonesia merdeka) majalah tersebut dapat diterbitkan lagi dibawah kendali Sutan Takdir Alisjahbana dan didukung oleh beberapa tokoh lain yaitu Achdiat Mihardja, Asrul Sani, Chairil Anwar, Dodong Djiwapradja, Haijadi S, dan Rivai Apin. Angkatan Pujangga Baru diwarnai oleh puisi- puisi terkenal karya Amir Hamzah yang dibukukan dalam Nyanyi Sunyi (1937) dan Buah Rindu (1947). Puisi-puisi karya Amir Hamzah secara umum bernada romantisisme: kerinduan dan rasa sedih yang menimbulkan rasa sunyi serta berpasrah diri. Beberapa sastrawan yang terkenal pada periode ini yaitu:

1. Sutan Takdir Alisjabana, karya-karyanya Dian yang Tak Kunjung Padam (roman, tahun 1932), Tebaran Mega (kumpulan sajak, tahun 1935), Layar Terkembang ( roman, tahun 1936), dan Anak Perawan di Sarang Penyamun (roman, tahun 1940)

2. Hamka, karya-karyanya: Di Bawah Lindungan Ka'bah (1938), Tenggelamnya Kapal Van Der Wijck (1939), Tuan direktur (1950) dan Di Dalam Lembah Kehidupan (1940)

3. Armijn Pane, karya-karyanya: Jiwa Berjiwa (1939), Gamelan Djiwa- kumpulan sajak (1960), Belenggu 
(roman, 1940), Djinak-djinak Merpati (sandiwara, tahun 1950), dan Kisah Antara Manusia (1953)

4. Sanusi Pane, karya-karyanya: Pancaran Cinta (1926), Puspa Mega (1927), Sandhykala Ning Majapahit (1933), dan Kertajaya (1932)

5. Tengku Amir Hamzah, karya-karyanya: Nyanyi Sunyi (kumpulan sajak, tahun 1937), Begawat Gita (1933), dan Setanggi Timur (1939)

\section{c.Angkatan 1945}

Pengalaman hidup dan adanya gejolak sosial-politikbudaya telah mewarnai karya sastra Angkatan '45. Sumardjo (dalam Yudiono, 2007) menjelaskan bahwa Proklamasi Kemerdekaan sangat berpengaruh terhadap kegiatan kebudayaan termasuk pada kesusastraan. Adanya pemikiran kebudayaan dan kesusastraan tersebut tampak adanya majalah-majalah yang terbit pasca kemerdekaan, misalnya Panca raya (1945-1947), Nusantara (1946-1947), Arena (1946-1948 di Yogyakarta), dan sebagainya. Karya sastra yang berkembang pada angkatan ini yaitu puisi, cerpen, novel, serta drama yang diwarnai dengan perang. Karya sastra pada angkatan ini dikatakan lebih realistik dibanding karya Angkatan Pujangga baru yang lebih bersifat romantikidealistik. Karya-karya sastra pada angkatan ini lebih banyak bercerita tentang perjuangan merebut kemerdekaan seperti puisi-puisi yang ditulis oleh Chairil Anwar. Karya yang terkenal pada masa ini adalah Atheis yang ditulis oleh Achadiat Kartamiharja dan Dari Ave Maria ke Jalan Lain ke Roma yang ditulis oleh Idrus. Beberapa sastrawan yang terkenal pada zaman ini yaitu: 
1. Chairil Anwar, karya-karyanya: Kerikil Tajam (1949) dan Deru Campur Debu (1949)

2. Asrul Sani, (bersama Rivai Apin dan Chairil Anwar), karyanya Tiga Menguak Takdir (1950)

3. Idrus, karya-karyanya: Dari Ave Maria ke Djalan Lain ke Roma (1948), Aki (novel, tahun 1949), dan Perempuan dan Kebangsaan (novel, 1949)

4. Achdiat K. Mihardja, karyanya: Atheis (roman, tahun 1949). Hingga tahun 2006 dicetak ulang sebanyak 28 kali. Bentrokan dalam Asrama (1952), Debu Cinta Bertebaran (1973), dan Pak Dullah in Extremis (drama, tahun 1973).

5. Trisno Sumardjo, karyanya: Katahati dan Perbuatan (1952)

6. Utuy Tatang Sontani, karya-karyanya: Suling (drama, tahun 1948), Tambera (1949), Sayang Ada Orang Lain (1954), Di Langit Ada Bintang (1955), Bunga Rumah Makan (1948) dan Awal dan Mira (drama satu babak, tahun 1962)

7. Suman Hs, karya-karyanya: Kasih ta' Terlarai (1961), Mentjari Pentjuri Anak Perawan (1957), dan Pertjobaan Setia (1940)

\section{d.Angkatan 1950-1960-an}

Pada angkatan ini tampak terlihat adanya kesadaran baru dikalangan para sastrawan untuk memikirkan beberapa permasalahan kemasyarakatan dalam suasana kemerdekaan. Para sastrawan pun mulai membuat orientasi baru dengan menggarap bahan-bahan dari sastra dan kebudayaan Indonesia. Adapun ciri dari angkatan ini adalah karya sastra 
yang didominasi dengan cerita pendek dan kumpulan puisi. Beberapa sastrawan yang terkenal pada angkatan ini yaitu:

1. Pramoedya Ananta Toer, karya-karyanya: Keranji dan Bekasi Jatuh (1947), Bukan Pasar Malam (1951), Di Tepi Kali Bekasi (1951), Keluarga Gerilya (1950), Mereka Yang Dilumpuhkan (1951), Bukan Pasar Malam (1951), Kumpulan cerpen subuh (1950), Panggil Aku Kartini Saja (novel, tahun 1962), Cerita Dari Blora (1952), dan Gadis Pantai (1965)

2. Nh. Dini, karya-karyanya: Dua Dunia (1950) dan Hati Jang Damai (1960)

3. Sitor Situmorang, karya-karyanya : Dalam Sadjak (1950), Djalan Mutiara: kumpulan tiga sandiwara (1954), Pertempuran dan Saldju di Paris (1956), Surat Kertas Hidjau: kumpulan sadjak (1953), dan Wadjah Tak Bernama: kumpulan sadjak (1955)

4. Muchtar Lubis, karya-karyanya: Tak Ada Esok (1950), Jalan Tak Ada Ujung (1952), Tanah Gersang (1964), Si Djamal (1964), Marius Ramis Dayoh, Putra Budiman (1951), dan Pahlawan Minahasa (1957)

5. Ajip Rosidi, karya-karyanya:Tahun-tahun Kematian (1955), Di Tengah Keluarga (1956), Sebuah Rumah Untuk Hari Tua (1957), Cari Muatan (kumpulan sajak, tahun 1959), Anak Tanah Air (novel, tahun 1979), dan Pertemuan Kembali (1961)

6. Ali Akbar Navis, karya-karyanya: Robohnya Surau Kami (cerita pendek pilihan) (1955), Bianglala- kumpulan cerita pendek (1963), Hujan Panas (1964), dan Kemarau (novel, tahun 1967) 


\section{e.Angkatan '66}

H.B Jassin merupakan pencetus Angkatan '66. Angkatan lahir bersamaan dengan kondisi politik Indonesia yang mengalami kekacauan dikarenakan adanya teror dan paham komunis yang merajalela. Kaum komunis bermaksud untuk mengambil alih kekuasaan Negara serta mengganti ideologi Pancasila dengan ideologi komunis. Oleh karena itu, karya sastra yang lahir pada periode ini lebih banyak berwarna protes terhadap keadaan sosial dan politik pemerintah pada masa itu.

Ciri-ciri sastra pada masa Angkatan '66 lebih bercorak pada perjuangan antitirani, protes terhadap keadaan sosial dan politik, anti kezaliman, membela keadilan, mencintai nusa, bangsa, negara dan persatuan, kesadaran moral, serta pembelaan terhadap Pancasila dan agama (Yudiono, 2007). Kelahiran Angkatan 66 merupakan klimaks terhadap tirani yang berkepanjangan dan semangat melawan tirani dituangkan melalui hasil kesenian atau kesusastraan. Angkatan ini ditandai dengan terbitnya majalah Horison yang dipimpin oleh Mochtar Lubis dan redaksinya adalah H.B Jassin, Taufiq Ismail, Zaini, Soe Hok Djin, dan D.S.Moeljanto. Majalah ini terbit pada bulan Juli 1966 setelah melewati ketegangan yang terjadi selama berbulan-bulan dalam penumpasan PKI. Penerbit dari majalah Horison yaitu Yayasan Indonesia yang didirikan pada tanggal 31 Mei 1966 yang memiliki visi mengembalikan krisis budaya yang terjadi selama belasan yahun agar tumbuh semangat baru untuk memperjuangkan demokrasi dan martabat manusia Indonesia. Majalah Horison juga mengajak masyarakat untuk meninggalkan ruang sempit yang mengungkung masyarakat 
selama puluhan tahun sehingga mendapat kehidupan yang baru dan terbebas dari kekuasaan yang monolitik (Yudiono, 2007). Dengan kesadaran penuh Majalah Horison meyakini bahwa bidang sastra memiliki kedudukan strategis dalam rangka mendorong kreatifitas pemikiran individu maupun bangsa. Majalah Horison mengutamakan sastra yang berbentuk cerpen, sajak, kritik, dan esai. Pada awal terbitnya Horison terdapat artikel penting yaitu Deklarasi Angkatan '66 oleh H.B Jassin yang dimuat pada bulan Agustus 1966 Nomor 2 yang berjudul "Angkatan 66:Bangkitnya Satu Generasi". Pengarang atau penyair yang sering disebut sebagai ikon pada angkatan ini yaitu Taufiq Ismail dengan buku puisinya yang berjudul Tirani, Mansur Samin dengan kumpulan sajaknya yang berjudul Perlawanan, Abdul Wahid Situmeang dengan kumpulan sajaknya yang berjudul Pembebasan. Beberapa sastrawan yang terkenal Angkatan 66 secara detail dapat diuraikan sebagai berikiut:

1.Taufik Ismail, karya-karyanya: Malu (Aku) Jadi Orang Indonesia (1998), Tirani dan Benteng (1993), Buku Tamu Musium Perjuangan (1972), Sajak Ladang Jagung (1973), dan Puisi-puisi Langit (1990).

2.Abdul Hadi WM, karya-karyanya: Laut Belum Pasang (1971), Meditasi (1976), Potret Panjung Pengunjung Pantai Sanur (1975), Anak Laut Anak Angin (1982), dan Tergantung Pada Angin (1977)

3.Nasjah Djamin, karya-karyanya: Hilanglah Si Anak Hilang (1963) dan Gairah Untuk Hidup dan Mati (1968) 


\section{f. Angkatan 70-an}

Karya sastra pada masa ini berbeda dengan karya sastra sebelumnya. Karya sastra pada masa ini kebanyakan tidak menekankan makna kata dan digolongkan sebagai karya sastra kontemporer yang dipelopori oleh Sutardji Calzoum Bachri. Contoh karya sastra kontemporer pada masa ini yaitu puisi Tragedi Winka \& Sihka oleh Sutardji Calzoum Bachri. Ciri umum yang dimiliki puisi Sutardji yaitu mengesampingkan unsur makna dan lebih menekankan pada unsur permainan bunyi dan bentuk grafis. Puisi-puisi Sutardji terkumpul dalam sebuah buku yang berjudul O, Amuk, Kapak yang diterbitkan pada 1981.

Puisi-puisi pada angkatan 70-an dipengaruhi oleh semangat avant-garde. Adapun aliran yang digunakan pun sangat beragam, yakni munculnya karya sastra beraliran surealis, arus kesadaran, arketip, absurd, dan sebagainya. Penerbit yang sangat membantu dalam menerbitkan karya sastra pada zaman ini adalah penerbit Pustaka Jaya. Prosa yang menonjol pada masa ini banyak menyuarakan sastra daerah dan novel-novel yang terbit pada tahun pertama hingga pertengahan 1970-an menampilkan beberapa gejala lokal dan kehidupan sehari-hari misalnya keluarga, kepercayaan, ritual, dan kebiasaan sebuah komunitas (Kosasih, 2008). Beberapa sastrawan yang terkenal pada masa ini yaitu:

1. Umar Kayam, karya-karyanya: Seribu Kunangkunang di Manhattan (kumpulan cerepen, tahun 1972), Sri Sumarah (kumpulan cerpen, tahun 1985), Para Priyayi (novel, tahun 1992), dan Jalan Menikung (novel, tahun 2000) 
2. Putu Wijaya, karya-karyanya: Bila Malam Bertambah Malam (1971), Pabrik (1977), Stasiun (1977), Telegram (1972), dan sebagainya.

3. Goenawan Muhamad, karya-karyanya: Perikesit (1971), Asmaradana (1972), dan Potret Seorang Penyair Muda Sebagai Si Malin Kundang ( Esai, 1972)

4. Supardi Djoko Damono, karya-karyanya: Duka-Mu Abadi (1969), Mata Pisau (1974), Akuarium (1974), Hujan Bulan Juni (1994), Arloji (1999), Ayat-Ayat Api (2000), dan sebagainya.

5. Arif Budiman, karya-karyanya: Buku Kritik Chairil Anwar : Sebuah Pertemuan (1976)

g. Angkatan ' 80 -an

Karya sastra Indonesia pada masa angkatan 80-an tersebar luas di berbagai majalah dan penerbit umum.Sedangkan karya sastra Indonesia pada masa ini lebih dominan dengan roman percintaan. Sastrawan wanita yang terkenal pada masa itu yaitu Marga T. Pada era ini juga banyak berkembang sastra yang beraliran pop remaja, yaitu dengan lahirnya sejumlah novel populer yang dipelopori oleh Hilman dengan serial Lupus, Remy Sylado, Yudistira Ardinugraha, Noorca Mahendra, Seno Gumira Ajidarma, dan Kurniawan Junaidi.

Beberapa sastrawan yang terkenal pada masa ini yaitu:

1. Y.B Mangunwijaya, karyanya: Burung-burung Manyar (1981), Roro Mendut (1983), Genduk Duku (1985), dan sebagainya. 
2. Budi Darma, karya-karyanya: Ny Talis (1996), Rafilus (1988), Solilokui (Kumpulan esai, 1983), dan sebagainya.

3. Arswendo Atmowilito, karyanya: Canting (1986), Semesta Merapi-Merbabu (novel, 1977), dan sebagainya.

4. Remy Silado, karya-karyanya: Ca Bau Kan (1999) dan Kerudung Merah Kirmizi (2002)

g. Angkatan Reformasi

Sastrawan Angkatan Reformasi muncul seiring adanya pergeseran kekuasaan politik pada saat itu, yaitu jatuhnya kekuasaan pemerintah Orde Baru. Karya sastra pada angkatan reformasi lebih merefleksikan keadaan sosial dan politik yang terjadi, seingga keadaan tersebut banyak melatarbelakangi kelahiran karya-karya sastra puisi, cerpen, dan novel yang bertema sosial politik khususnya terkait reformasi. Berbagai pentas pembacaan sajak dan penerbitan buku antologi puisi juga didominasi oleh sajak-sajak yang bertema tentang sosialpolitik. Sastrawan yang terkenal pada zaman ini yaitu Widji Thukul dengan karyanya dan Puisi Pelo dan Darman. Bahkan, penyair-penyair yang awalnya jauh dari tema sosial politik, seperti Sutardji Calzoum Bachri,Ahmadun Yosi Herfanda, dan Acep Zamzam Noer, ikut meramaikan suasana dengan sajak-sajak social politik mereka (Kosasih, 2008).

h. Angkatan 2000-an

Angkatan 2000 ditandai oleh karya-karya yang memilki gaya penulisan yang berani dan vulgar. Contoh karya sastra yang menonjol pada masa ini yaitu karya Ayu Utami yang berjudul Saman dan Larung sebagai kelanjutan dari Saman. Pada masa ini juga muncul karya-karya Islami sebagai 
penyeimbang adanya karya-karya yang sifatya vulgar. Karya fiksi islami ini ditulis dengan pendekatan islami baik dari tema maupun pengemasannya. Bahasa yang digunakan pun juga lebih santun agar tidak menimbulkan kesan yang erotis atau vulgar. Karya fiksi islami ini didominasi oleh para penulis perempuan.

Beberapa sastrwana yang terkenal pada masa ini yaitu:

1. Ayu Utami, karya-karyanya: Saman (1998) dan Larung (2001)

2. Dewi Lestari, karya-karyanya: Supernova 1: Ksatria Putri dan Bintang Jatuh (2001), Supernova 2.1: Akar (2002), dan Supernova 2: 2 Petir (2004)

3. Habiburrahman El Shirazy, karya-karyanya: Ayat-ayat Cinta (2004), Di Atas Sajadah Cinta (2004), Ketika Cinta Berbuah Surga (2005), Pudarnya Pesona Cleopatra(2005), Ketika Cinta Bertasbih 1 (2007), Ketika Cinta Bertasbih 2 (2007), dan Dalam Mihrab Cinta (2007)

4. Andrea Hirata, karya-karyanya: Laskar Pelangi (2005), Sang Pemimpi (2006), Edensor (2007), Maryamah Karpov (2008), dan Padang Bulan dan Cinta Dalam Gelas (2010)

\section{E. RANGKUMAN}

a. Sastra merupakan suatu ungkapan pribadi manusia berupa pengalaman, pemikiran, perasaan, ide, serta keyakinan yang mampu membangkitkan pesona dengan alat bahasa. 
b. Sastra lama disebut juga sastra klasik atau kesusastraan tradisional merupakan sastra yang berkembang sebelum masuknya pengaruh Barat ke Indonesia.

c. Beberapa contoh karya sastra lama yaitu mantra, pantun, talibun, pantun kilat, gurindam, syair, peribahasa, teka-teki, fabel, legenda, dan hikayat.

d. Sastra Indonesia modern merupakan karya sastra yang berkembang pada abad 20-an.

e. Karya sastra lama memiliki beberapa ciri, yaitu:

- Nama pengarang tidak diketahui (anonim)

- Cerita yang dsajikan banyak diwarnai oleh hal gaib (Pralogis)

- Kata-kata yang digunakan banyak menggunakan bahasa baku, misalnya alkisah, konon, dan sebagainaya.

- Cerita yang disajikan berupa kehidupan istana, dewa, pahlawan, dan sebagainya.

- Berkembang secara lisan, karena belum ada media cetak atau elektronik.

f. Karya sastra baru memiliki beberapa ciri yaitu:

- Bertema tentang kehidupan masyarakat seharihari, misalnya mengenai adat, pekerjaan, persoalan rumah tangga, serta adat.

- Mendapat pengaruh dari kesusastraan Barat. Hal ini bisa dilihat dari tema serta tokoh-tokoh dalam cerita.

- Nama pengarangnya dinyatakan dengan jelas.

g. Karya sastra modern terdiri dari beberapa angkatan, yaitu Angkatan Balai Pustaka, Angkatan Pujangga Baru, Angkatan '45, angkatan '66, angkatan 70 an, 
angkatan 80 an, angkatan reformasi, dan angkatan 2000.

h. Roman-roman angkatan Balai Pustaka memiliki ciri umum, diantaranya:

- Bersifat kedaerahan

- Bersifat romantic-sentimental

- Bergaya bahasa seragam karena dikelola oleh Balai Pustaka sehingga tidak ada gaya bahasa perorangan

- Bertemakan sosial

i. Beberapa sastrawan yang terkenal pada Angkatan Balai Pustaka diantaranya: Merari siregar, Marah Roesli, Muhammad Yamin, Nur Sultan Iskandar, Abdul Muis, Lulis Sutan Suti, Djamaluddin Adinegoro, dan Aman Datuk Madjoindo.

j. Beberapa sastrawan yang terkenal pada angkatan Pujangga Baru yaitu: Sutan Takdir Alisjabana, Hamka, Armijn Pane, Sanusi Pane, dan Tengku Amir Hamzah.

k. Beberapa sastrawan yang terkenal pada Angkatan 45 yaitu: Chairil Anwar, Asrul Sani, Idrus, Achdiat K. Mihardja, Trisno Sumardjo, Utuy Tatang Sontani, dan Suman Hs.

1. Beberapa sastrawan yang terkenal pada angkatan 1950-1960 yaitu: Pramoedya Ananta Toer, Nh. Dini, Muchtar Lubis, Ajip Rosidi, dan Ali Akbar Navis

m. Beberapa sastrawan yang terkenal pada Angkatan 66 yaitu: Taufik Ismail, Abdul Hadi WM, dan Nasjah Djamin. 
n. Beberapa sastrawan yang terkenal pada angkatan 70 an yaitu: Umar Kayam, Putu Wijaya, Goenawan Muhamad, Supardi Djoko Damono, dan Arif Budiman.

o. Beberapa sastrawan yang terkenal di angkatan 80 an yaitu: Y.B Mangunwijaya, Budi Darma, Arswendo Atmowilito, dan Remy Silado.

p. Beberapa sastrwan yang terkenal di angkatan 2000 an yaitu: Ayu Utami, Dewi Lestari, Habiburrahman E1 Shirazy, dan Andrea Hirata

\section{F. SOAL EVALUASI}

1. Jelaskan apa yang dimaksud dengan sastra!

2. Diskusikan dengan teman sekelompokmu mengenai sejarah sastra Indonesia dan jelaskan masing-msing perbedaan antara sastra lama dan sastra modern!

3. Jelaskan mengenai sejarah sastra menurut Rosidi!

4. Jelaskan mengenai perbedaan karya sastra angkatan Balai Pustaka dengan Pujangga Baru!

5. Jelaskan perbedaan karya sastra angkatan 66 dan angkatan 70 an!

6. Bacalah masing-masing satu karya sastra angkatan Balai Pustaka dan Pujangga Baru kemudian buatlah ringkasan ceritanya! 


\section{BAB VIII \\ JENIS DAN BENTUK KARYA SASTRA}

\section{Tujuan Instruksional}

Mahasiswa mampu memahami jenis dan bentuk karya sastra

\section{A. JENIS-JENIS SASTRA}

Berdasarkan jenis bahasa maupun isinya, jenis (genre) sastra dikelompokkan menjadi dua yaitu sastra imajinatif dan sastra non imajinatif (Sumarjo dan Saini ,1986)

\section{Sastra Imajinatif}

Imajinasi bisa diartikan sebagai khayalan atau anganangan. Karya sastra imajinatif merupakan jenis karya sastra yang ditulis berdasarkan hasil khayalan penulis, akan tetapi masuk akal dan mengandung kebenaran yang mendramatisasikan hubungan antar manusia (Altenbernd dan Lewis (dalam Nurgiyantoro 2006). Sebuah karya atau cerita imajinatif berarti bukan merupakan suatu kejadian yang sebenarnya, akan tetapi pengarang mengemukakan hal tersebut berdasarkan pengalaman dan pengamatan terhadap kehidupan. Karya imajinatif bisa dikelompokkan menjadi dua jenis yaitu prosa dan puisi. Prosa merupakan sebuah karya naratif yang hanya bersifat fiktif atau tidak benar-benar terjadi di kehidupan nyata. Karena prosa merupakan karya yang imajinatif, maka tokoh, peristiwa, serta setting dalam prosa pun bersifat imajiner, sedangkan tokoh, peristiwa, dan seting dalam karya-karya non fiksi lebih bersifat faktual artinya terjadi di kehidupan nyata. Prosa fiksi mengandung 
beberapa unsur yang mencakup pengarang atau narator, isi penciptaan, bahasa, serta elemen-elemen pembangun karya sastra tersebut.

Adapun pemaparan isi dari karya prosa bisa dilakukan oleh pengarang melalui penjelasan ataupun komentar, melalui dialog maupun monolog, serta melalui lakon. Prosa dikelompokkan lagi menjadi dua jenis yaitu dari prosa fiksi dan drama. Prosa fiksi mencakup novel maupun roman, cerpen, dan novel pendek atau disebut juga sebagai novelet.

\section{Sastra Non-Imajinatif}

Sastra non-imajinatif merupakan sebuah karya sastra yang lebih menonjolkan unsur fakta dari pada unsur khayalan. Penggunaan bahasa pada sastra non imajinatif lebih bersifat denotatif. Beberapa contoh karya sastra astra non-imajinatif yaitu esai, kritik, biografi, otobiografi, sejarah, catatan harian, dan surat.

\section{B. UNSUR KARYA SASTRA INDONESIA}

Sebuah karya sastra yang baik dibangun dari beberapa unsur yang menjadikannya sebagai satu kesatuan yang utuh. Sebuah karya sastra setidaknya terbentuk dari dua unsur dasar, yakni unsur instrinsik atau unsur dari dalam karya sastra yang membangun terciptanya sebuah karya sastra dan unsur ekstrinsik yakni unsur dari luar yang turut mempengaruhi terciptanya karya sastra.

\section{Unsur karya sastra fiksi}

a.Unsur intrinsik 
Unsur intrinsik merupakan unsur-unsur yang membangun karya sastra itu sendiri. Unsur-unsur intrinsik tersebut secara langsung turut serta membangun cerita, oleh karena itu keberadaan unsur intrinsik sangat diperlukan. Unsur intrinsik sebuah karya sastra mencakup alur atau plot, tokoh, tema, latar atau setting, sudut pandang, bahasa atau gaya bahasa. (Nurgiyantoro, 2009).

\section{Setting}

Setting atau disebut juga latar merupakan tempat, hubungan waktu, dan lingkungan sosial tempat terjadinya peristiwa yang diceritakan. Latar tempat mengacu pada tempat terjadinya peristiwa yang diceritakan. Latar harus didukung oleh kehidupan sosial masyarakat, nilai, tingkah laku, dan suasana yang bisa berpengaruh terhadap penokohan dan pengalurannya (Nurgyantoro, 2009). Latar waktu mengacu pada saat terjadinya peristiwa yang diceritakan, atau mengacu pada waktu penulisan cerita dan urutan waktu kejadian yang dikisahkan dalam cerita. Sedangkan latar sosial menggambarkan perilaku kehidupan sosial masyarakat yang berhubungan dengan kebiasaan hidup, adat istiadat, tradisi, keyakinan, pandangan hidup, cara berfikir dan bersikap yang tercermin dalam kehidupan masyarakat yang kompleks (Nurgyantoro, 2009). Setting tidak hanya berupa fisik dalam suatu cerita, akan tetapi juga bersifat psikologis yang mampu menggambarkan suasana tertentu sehingga mampu menggerakkan emosi pembacanya.

\section{Tema}


Tema merupakan ide yang mendasari sebuah cerita sehingga oleh pengarang dijadikan sebagai pangkal untuk memaparkan karya fiksi yang diciptakannya. Tema dapat dikatakan sebagai hal penting dalam seluruh cerita. Tema yang diangkat dalan sebuah cerita dalam karya sastra bisa berupa hal-hal yang berkaitan erta dalam kehidupan, misalnya persoalan moral, kekuasaan, kasih sayang atau percintaan, etika, agama, sosial budaya, teknologi, serta tradisi. Berdasarkan jenisnya, tema dibedakan menjadi dua, yaitu tema mayor dan tema minor (Nurgiyantoro, 2009). Tema mayor merupakan tema pokok atau permasalahan yang dominan yang terdapat dalam sebuah cerita. Sedangkan tema minor atau tema bawahan merupakan tema yang mendukung tema mayor, permasalahan yang digambarkan dalam sebuah cerita merupakan cabang dari tema mayor.

Beberapa karya sastra yang tumbuh di zaman yang berbeda akan melahirkan tema yang berbeda pula, semua dipengaruhi oleh kehidupan pada zamannya. Sebagai contoh tema karya sastra pada zaman sebelum kemerdekaan akan berbeda dengan karya setelah kemerdekaan. Karya sastra yang lahir sebelum kemerdekaan lebih banyak membahas tentang persoalan adat mupun romantisme budaya, sedangkan pada zaman kemerdekaan dan sesudahnya karya sastra lebih mengedepankan unsur individualitas dan kebebasan. Pada masa setelah reformasi karya sastra lebih menekankan pada tema yang terkait dengan persoalan HAM dan demokrasi. 
Tema dalam sebuah cerita jarang sekali disampaikan secara langsung oleh pengarang, agar dapat merumuskan atau memahami tema sebuah karya fiksi, maka pembaca perlu mengenali unsur-unsur intrinsik yang dipakai oleh pengarang atau dengan kata lain, pembaca perlu melakukan apresiasi menyeluruh terhadap berbagai unsur karya sastra tersebut. Menurut Kosasih (2008) ada empat unsur intrinsik yang biasanya digunakan oleh pengarang dalam menyalurkan tema dalam sebuah cerita, yaitu melalui alur, penokohan, bahasa, serta simbol-simbol yang dipakai oleh pengarang.

Pengarang sering kali menyampaikan tema melalui alur cerita. Ketika seorang pembaca memahami peristiwa yang terjadi dalam sebuah cerita, maka pembaca akan menemukan beberapa peristiwa yang diurutkan berdasarkan sebab akibat, yaitu peristiwa A mengakibatkan peristiwa B, dan seterusnya. Selain alur, pengarang seringkali menyampaikan tema melalui tokoh yang ada dalam sebuah cerita. Penokohan meliputi peran dan sifat-sifat tokoh yang diciptakan oleh pengarang. Berbagai sifat yang dimiliki oleh tokoh cerita sengaja diciptakan oleh pengarang untuk dimuat dalam tema, misalnya tokoh antagonis dipertentangkan dengan tokoh protagonis. Bahasa atau dialog yang diucapkan oleh para tokoh dalam sebuah cerita serta komentar pengarang terhadap peristiwa-peristiwa yang terjadi dalam sebuah cerita bisa dijadikan sebagai media pengarang dalam menyampaikan sebuah tema.

\section{Gaya bahasa}

Gaya bahasa merupakan cara yang digunakan oleh pengarang untuk membangun estetika dalam sebuah cerita. 
Selain itu penggunaan bahasa dalam sebuah cerita berfungsi untuk mencipta nada atau suasana persuasif dan merumuskan dialog yang mampu memperlihatkan hubungan dan interaksi antartokoh. Bahasa juga mampu menggambarkan atau menandai karakter tokoh dalam sebuah cerita, misalnya karakter jahat menggunakan bahasa atau kata-kata yang kasar, tidak sopan, dan sebagainya. Sebaliknya tokoh yang baik menggunakan kata-kata yang baik, bijak, serta santun. Dalam hal ini, seorang pengarang mengolah sebuah cerita melalui gaya bahasa, pilihan kata, majas, gaya retoris agar menghasilkan sebuah karya sastra yang mengandung nilai estetis. Nurgiyantoro (1994: 273) menjelaskan bahwa pada umumnya bahasa yang ada dalam karya sastra mengandung unsur emotif.

\section{Sudut pandang}

Sudut pandang merupakan cara seorang pengarang dalam menampilkan para pelaku di dalam sebuah cerita (Aminuddin, 2011). Sudut pandang dibagi menjadi dua yaitu sudut pandang orang pertama dan sudut pandang orang ketiga. Sudut pandang orang pertama dibagi menjadi sudut pandang akuan sertaan atau disebut dengan first person central dan sudut pandang akuan tak sertaan atau disebut juga dengan first person peripheral. Dalam sudut pandang akuan sertaan, tokoh utama dalam sebuah cerita disampaikan dengan menggunakan kata ganti aku. Sedangkan sudut pandang akuan tak sertaan, pencerita merupakan tokoh pembantu yang hanya muncul di awal dan di akhir dalam sebuah cerita.

\section{Tokoh}


Dalam sebuah karya fiksi, ada beberapa istilah mengenai tokoh, penokohan, watak, karakter, serta perwatakan. Beberap istilah tersebut mempunyai arti yang berbeda. Tokoh merupakan pelaku cerita, sedangkan penokohan lebih merujuk pada cara pengarang dalam menampilkan tokohtokoh dan watak-wataknya dalam suatu cerita (Nurgyantoro, 2009). Tokoh dalam sebuah cerita tidak hanya berwujud manusia, akan tetapi bergantung pada apa yang diceritakan dalam sebuah cerita. Sedangkan watak atau karakter merupakan sifat dan sikap para tokoh tersebut dalam sebuah cerita.

Menurut Suyanto (2012) dalam menampilkan tokoh dan watak dalam sebuah cerita, ada beberapa cara yang dapat digunakan oleh pengarang, yaitu :

1) Metode telling, yaitu pemaparan watak tokoh dengan cara mengandalkan eksposisi dan komentar langsung dari pengarang. Dengan menggunakan metode telling ini, para pembaca akan lebih mudah memahami dan menghayati perwatakan dari tokoh sebuah cerita melalui penuturan langsung dari pengarang.

2) Metode showing, pengarang menggambarkan karakteristik tokoh dengan cara tidak langsung, atau tanpa ada penuturan langsung dari pengarang. Pengarang menyajikan karakteristik tokoh melalui dialog dan tingkah tokoh.

Nurgiyantoro (2009) membedakan tokoh dalam beberapa jenis penanaman berdasarkan dari sudut mana penamaan itu dilakukan. Berdasarkan sudut pandang dan tinjauan,tokoh dapat dikategorikan dalam beberapa jenis yaitu a) Tokoh utama dan tokoh tambahan. Tokoh utama 
merupakan tokoh yang diutamakan dalam sebuah cerita, sedangkan tokoh tambahan merupakan tokoh yang tidak terlalu diprioritaskan dalam cerita, tokoh tambahan ini pemunculan dalam sebuah cerita lebih sedikit dibandingkan tokoh utama. Tokoh tambahan berfungsi untuk melengkapi, dan mendukung tokoh utama. Perbedaan tersebut didasarkan pada segi peranan. b) Tokoh protagonis merupakan tokoh yang dikagumi dalam sebuah cerita, karena tokoh protagonis merupakan pengejawantahan dari norma-norma dan nilainilai yang ideal bagi kita. Sebaliknya, tokoh antagonis merupakan tokoh yang memiliki watak kurang baik, biasanya menyebabkan konflik dalam sebuah cerita. Perbedaan peranan ini berdasarkan fungsi penampilan tokoh. c) Tokoh sederhana dan tokoh bulat. Tokoh sederhana merupakan tokoh yang hanya memiliki satu kualitas sisi kepribadian yang diungkapkan oleh pengarang. d) Tokoh statis dan tokoh dinamis. Tokoh statis merupakan tokoh yang tidak mengalami pengembangan perwatakan sebagai akibat terjadinya konflik, sedangkan tokoh dinamis merupakan tokoh yang mengalami pengembangan perwatakan.

Untuk memahami watak tokoh dalam sebuah cerita, pembaca bisa menilai dari beberapa hal, diantaranya melalui (a) tuturan pengarang dalam menggambarkan karakteristik pelaku, (b) melalui gambaran tentang lingkungan kehidupan atau cara berpakaian, (c) gambaran bagaimana tokoh tersebut berbicara pada dirinya sendiri, (d) gambaran bagaimana tokoh lain berbicara tentang tokoh tersebut, (e) melalui bagaimana jalan pikiran tokoh tersebut, serta (f) reaksi antara tokoh dengan tokoh lainnya. 


\section{Alur atau plot}

Alur merupakan rangkaian cerita yang dibentuk oleh tahapan-tahapan peristiwa yang saling berkaitan sehingga menjadi sebuah cerita (Suyanto (2012). Alur dapat dianalisis dengan cara mencari dan mengurutkan beberapa peristiwa yang memiliki hubungan sebab akibat. Tarigan (2011) menjelaskan bahwa alur merupakan struktur gerak yang terdapat dalam fiksi atau drama. Alur bergerak dari suatu permulaan, pertengahan dan menuju akhir (ending). Tahap permulaan merupakan tahapan dimana pengarang memberikan informasi penting kepada pembaca, yang meliputi para tokoh, situasi para tokoh, merencanakan konflik yang akan terjadi, serta memberikan suatu indikasi mengenai resolusi dalam suatu cerita. Sedangkan pada bagian tengah (middle) pengarang mengembangkan konflik atau masalah yang muncul dari sebuah cerita. Sedangkan tahap akhir atau ending pengarang memberikan pemecahan masalah dari semua peristiwa yang terjadi dalam sebuah cerita. Alur dalam sebuah cerita mengatur jalinan peristiwa yang dialami oleh tokoh dalam hubungan sebab akibat, dengan kata lain peristiwa yang satu menyebabkan terjadinya peristiwa yang lain.

Sedangkan menurut Kosasih (2008) jalan cerita secara umum terbentuk beberapa bagian, diantaranya :

a. Pengenalan situasi cerita (exposition). Pada tahap ini pengarang memperkenalkan tokoh yang dikisahkan dalam cerita sertamenata adegan

b. Pengungkapan peristiwa (complication). Pada bagian ini peristiwa yang menimbulkan masalah maupun pertentangan bagi tokoh cerita mulai disajikan 
c. Adanya konflik (rising action). Pada bagian ini mulai terjadi peningkatan kegembiraan, kehebohan situasi yang menyebabkan kesulitan bagi para tokoh.

d. Terjadinya puncak konflik (klimaks/ turning point). Pada bagian ini pengarang memaparkan cerita tentang perubahan nasib dari para tokoh misalnya keberhasilan dalam menyelesaikan masalah.

e. Penyelesaian (ending). Tahap ini merupakan ekhir dari cerita yang berisi tentang nasib dari para tokoh setelah mengalami beberapa peristiwa. Penyelesaian cerika ini tidak selamanya dipaparkan langsung oleh pengarang, akan tetapi diserahkan pada imajinasi pembaca (akhir cerita dibiarkan menggantung, tanpa ada penyelesaian).

Beberapa susunan alur di atas terkadang tidak terjadi secara berurutan, terkadang tahapan ceritanya langsung pada bagian penyelesaian, lalu mengarah pada pengenalan, penyelesaian peristiwa dan terakhir menuju pada puncak konflik.

Pada umumnya alur sebuah cerita dikelompokkan menjadi : a) Alur tunggal, merupakan alur yang hanya terjadi pada sebuah cerita yang hanya memiliki satu jalan cerita saja. Alur tunggal biasanya terdapat pada cerpen. b) Alur ganda, merupakan alur yang terjadi pada cerita yang memiliki alur lebih dari satu. c) Alur mundur, flash-back, sorot balik merupakan alur yang mengisahkan kejadian yang tidak bersifat kronologis d) Alur maju adalah alur yang bersifat kronologis. Menurut Nurgyantoro (2012), jika dilihat berdasarkan urutan waktunya alur atau plot dapat dibedakan menjadi beberapa kriteria yaitu : 
a. Plot lurus atau progresif, plot ini ditandai dengan adanya beberapa peristiwa yang terjadi secara berurutan, sehingga dapat memunculkan peristiwa lainnya.

b. Plot sorot-balik atau flash-back, plot ini ditandai dengan adanya penceritaan peristiwa yang tidak berurutan, cerita bisa dimulai dari tengah ataupun akhir cerita.

c. Plot campuran, plot ini merupakan plot gabungan antara plot progresif dan plot sorot balik.

Perlu diketahui bahwasannya alur yang dikembangkan pada sebuah novel berbeda dengan alur dalam cerpen. Cerita yang dikembangkan dalam novel lebih rumit dan terkadang berbelit-belit, penuh kejutan sedangkan cerita dalam cerpen dikisahkan secara sederhana.

\section{Amanat}

Amanat merupakan ajaran moral atau pesan yang ingin disampaikan oleh pengarang kepada pembaca baik secara eksplisit maupun implisit (Sudjiman, 1988). Wujud amanat dapat berupa jalan keluar yang diajukan pengarang terhadap permasalahan dalam sebuah cerita, atau bisa berupa pandangan hidup pengarang tentang nilai-nilai kebenaran yang ingin disampaikan kepada pembaca.

\section{b.Unsur Ekstrinsik}

Unsur ekstrinsik merupakan segala faktor yang melatarbelakangi penciptaan sebuah karya sastra. Unsur ekstrinsik berada di luar karya sastra, akan tetapi secara tidak 
langsung mempengaruhi bangunan karya sastra itu. Unsur ekstrinsik sebuah karya sastra terdiri dari beberapa unsur, yang mencakup latar belakang kehidupan pengarang, keyakinan dan pandangan hidup pengarang, adat istiadat yang berlaku saat itu, situasi politik dan ekonomi, persoalan sejarah, pengetahuan agama dan sebagainya (Suroto, 1989). Beberapa unsur ekstrinsik tersebut mencakup berbagai aspek kehidupan sosial yang menjadi latar belakang penyampaian tema dan amanat cerita dan cukup berpengaruh terhadap totalitas keterpaduan cerita yang dihasilkan.

\section{Unsur Puisi}

Waluyo (1995) menjelaskan bahwa puisi memiliki beberapa unsur yang ditinjau dari struktur fisik puisi dan struktur batin puisi.

\section{a. Struktur fisik puisi}

Struktur fisik puisi meliputi beberapa unsur, diantaranya:

(1) Perwajahan / tipopgrafi puisi yaitu unsur pembeda antara puisi dengan drama dan prosa. Baris-baris puisi berbentuk bait, tidak berbentuk paragraf.

(2) Diksi atau pilihan kata. Kata-kata yang digunakan dalam puisi harus dipilih secara cermat, agar menghasilkan katakata yang puitis dan memiliki nilai estetik. Selain itu katakata dalam puisi memiliki kedudukan yang sangat penting karena berkaitan dengan makna. Kata-kata dalam puisi bersifat konotatif dan makna kata-kata tersebut bisa lebih dari satu. (3) Pengimajian yaitu gambaran visual melalui penyusunan kata sehingga tercipta makna yang jelas, serta menimbulkan khayalan atau imajinasi. Dengan daya imajinasi, pembaca seolah-olah merasa, mendengar atau 
melihat sesuatu yang diungkapkan oleh penyair dalam sebuah puisi.

(3) Kata konkrit yaitu kata yang diguankan oleh penyair untuk menggambarkan keadaan maupun suasana batin yang bertujuan untuk membangkitkan imaji pembaca. (4) bahasa figurative atau disebut dengan majas.

(5) Verifikasi yang meliputi rima (pengulangan bunyi pada bait maupun baris puisi agar menjadi indah), sedangkan ritma (pergantian naik turun, panjang pendek, keras lembut dari suatu bunyi).

(6) Bahasa Figuratif (Majas), yaitu bahasa yang digunakan oleh penyair untuk mengatakan sesuatu dengan cara membandingkannya dengan benda atau kata lain. Dengan kata lain, majas digunakan untuk mengiaskan atau menyamakan sesuatu dengan hal lain.

\section{b. Struktur batin puisi}

Struktur batin puisi mencakup beberapa unsur yaitu (1) tema, (2) tone, (3) feeling, dan (4) amanat atau tujuan (Tarigan, 1985).Tema merupakan pemikiran seorang pengarang dalam menciptakan sebuah puisi atau disebut juga sebagai dasar dari suatu puisi (Aminudin, 1987). Menurut Waluyo (dalam Kosasih, 2008) tema puisi dibedakan menjadi beberapa jenis yaitu tema ketuhanan, kemanusiaan, patriotisme/kebangsaan, kedaulatan rakyat, dan keadilan sosial. Tema tersebut mengikuti is dari Pancasila. Tema ketuhanan menggambarkan pengalaman batin, keyakinan, serta sikap penyair terhadap Tuhan. Beberapa nilai ketuhahan tersebut tampak pada diksi, ungkapan, ataupun lambing dari puisi, contoh puisi Khotbah karya W.S. Rendra. 
Tema kemanusiaan bermaksud mengungkapkan meyakinkan pembaca mengenai persamaan harkat dan martabat manusia. Adanya perbedaan pangkat,kekayaan serta kedudukan tidak boleh menimbulkan perbedaan perlakuan. Contoh puisi yang bertema kemanusiaan yaitu Gadis peminta-minta karya Toto Sudarto Bachtiar.Tema patriotisme yaitu menggambarkan perjuangan merebut kemerdekaan atau perjuangan para pahlawan dalam melawan penjajah. Tema patriotisme digambarkan melalui pesan penyair untuk mengembangkan rasa cinta tanah air. Contoh puisi yang bertema patriotism yaitu Diponegoro karya Chairil Anwar. Tema kedaulatan rakyat menggambarkan tentang sikap kesewenang-wenangan terhadap rakyat, contoh puisi berjudul Rakyat karya Hartoyo Andangjaya. Tema keadilan sosial menggambarkan atau menyuarakan kemiskinan dan kesenjangan sosial, contoh Potret Pembangunan dalam Puisi karya Rendra. Puisi angkatan ' 66 banyak bertemakan keadilan sosial.

Tone atau nada merupakan sikap seorang penyair terhadap pembaca sejalan dengan pokok pikiran yang disampaikan (Aminudin, 1987). Sikap yang disampaikan penyair bisa berupa ejekan, menggurui, nasehat, atau bisa berupa sindiran.

Feeling merupakan suatu bentuk ekspresi atau sikap penyair terhadap pokok persoalan yang terkandung dalam sebuah puisi yang mewakili perasaan penyair. Bentuk ekspresi yang diungkapkan oleh penyair dalam sebuah puisi lebih dipengaruhi oleh latar belakan sosiologis dan psikologis yang terbentuk dalam sebuah kepribadian, 
pengalaman, dan pengetahuan penyair. Bentuk-bentuk ekspresi yang dituangkan oleh penyair berupa rasa rindu, kegelisahan, pengagungan kepada Tuhan, rasa kasih terhadap manusia, dan sebagainya. Amanat yaitu pesan yang hendak disampaikan penyair melalui karya sastranya. Amanat biasanya duingkapkan secara implisit oleh penyair.

\section{BENTUK KARYA SASTRA}

1. Prosa

Prosa merupakan karya naratif yang bersifat fiksi yang berarti hanya sebuah imajinasi atau rekaan (Nurgiyantoro, 2006). Prosa diungkapkan oleh pengarang dengan mendramatisir hubungan-hubungan antar manusia namun mengandung nilai-nilai kebenaran dan masuk akal. Pengarang mengemukakan sebuah cerita berdasarkan pengalaman maupun pengamatan terhadap kehidupan nyata. Prosa terdiri dari beberapa jenis yaitu prosa lama dan prosa baru.

\section{a).Prosa Lama}

Prosa lama merupakan prosa yang berkembang dalam masyarakat lama, yaitu masyarakat tradisional di Indonesia. Istilah prosa lama juga dikenal dengan folklore atau cerita rakyat yang terjadi dalam kehidupan rakyat serta diwariskan dari generasi ke generasi secara lisan. Beberapa contoh prosa lama yaitu hikayat, dongeng, mite, legenda, fabel, dan sebagainya. Hikayat merupakan salah satu bentuk prosa lama yang bercerita tentang kehidupan para raja dan tokoh. Riwayat hidup atau kehidupan tokoh yang diceritakan 
adakalanya realistis sesuai dengan sumber informasi dan data yang valid, akan tetapi bisa juga sumber penceritaannya bercampur baur antara fakta dan fiksi atau berasal dari opini penulisnya. Hikayat terbagi menjadi beberapa jenis yaitu:

1) Cerita rakyat, misalnya Hikayat Si Miskin dan Hikayat Malin Dewa;

2) Epos dari India, misalnya Hikayat Sri Rama;

3) Dongeng-dongeng dari Jawa, misalnya Hikayat Pandawa Lima

4) Cerita-cerita Islam, misalnya Hikayat Raja Khaibar;

5) Sejarah dan biografi, misalnya Hikayat Abdullah;

6) Cerita berbingkai, misalnya Hikayat Hikayat Maharaja Ali.

Secara garis besar hikayat memiliki beberapa unsur, diantaranya:

1) Unsur dalam Hikayat Jenis Rekaan, :

- Dalam struktur penceritaan, istana dan kehidupannya menduduki peranan yang sangat penting

- Penceritaan bertujuan untuk menghibur, membawa para pembaca ke dalam alam impian keindahan dan kemegahan

- Tokoh utamanya selalu mendapat kemenangan dan kebahagiaan (terkadang serba tidak terduga)

- Lebih menekankan pada pentingnya ajaran moral, misalnya kearifan mengalahkan kelicikan, kesederhanaan mengalahkan keserakahan, dan keadilan mengalahkan kezaliman

- Cerita memilki pola stereotip, yaitu mengenai peperangan antar kerajaan, keajaiban dan 
kekuatan gaib, serta percintaan antara tokohtokoh istana.

2) Unsur dalam Hikayat Jenis Sejarah:

- Menyebutkan nama tempat yang memang benar adanya dalam peta sesungguhnya, misalnya Majapahit dan Negeri Cina.

- Tokoh-tokoh yang diceritakan merupakan tokoh kerajaan dan dikaitkan dengan tokoh besar lainnya, misalnya Nabi Adam, Iskandar Zulkarnain, dan sebagainya

- Cerita yang dikisahkan berupa silsilah suatu dinasti, misalnya Hikayat Banjar

- Dipenuhi oleh unsur cerita-cerita fiktif.

3) Unsur dalam Hikayat Jenis Biografi:

- Latar belakang cerita berangkat dari peristiwa sejarah atau peristiwa-peristiwa yang pernah terjadi me

- Unsur cerita focus pada kelebihan tokoh yang diceritakan misalnya moralitas, dan ilmunya.

- Tidak lepas dari unsur-unsur fiktif.

Dongeng merupakan sebuah cerita fiktif yang berasal dari imajinasi pengarang. Tema yang diangkat dalam cerita dongeng bersifat fiktif akan tetapi peristiwa atau tingkah laku para tokohnya bisa saja terjadi dalam kehidupan sehari-hari. Dongeng dikelompokkan menjadi beberapa jenis yaitu : a) Dongeng jenaka, yaitu dongeng yang bersifat menghibur atau komedi yang mampu membangkitkan tawa pembaca, misalnya Cerita Si Kabayan, b) Mite, yaitu dongeng yang menceritakan tentang para Dewa atau makhluk halus, misalnya Dongeng Dewi Sri, c) Legenda, yaitu dongeng yang 
menceritakan peristiwa yang berhubungan dengan keajaiban alam atau asal-usul sebuah tempat, misalnya Legenda Asal usul Danau Toba, d) Sage, yaitu dongeng yang menceritakan seorang tokoh yang berhubungan dengan sejarah, dan terdapat tambahan cerita yang bersifat khayal karena menyebar dari mult ke mulut, misalnya cerita Lutung Kasarung.

Kosasih (2008) menjelaskan bahwa dongeng memiliki karakteristik yang menarik karena tokohnya menghibur dan lucu, jalan cerita menegangkan, temanya baru, tempat dan kejadian dalam cerita sangat berkesan. Dongeng tidak hanya sebagai sarana hiburan akan tetapi mengandung nilai edukasi karena mengandung pesan moral yang disampaikan melalui cerita.

b).Prosa Baru

Prosa baru bisa diartikan sebagai karya sastra yang telah mendapat pengaruh dari sastra Barat. Prosa baru dibedakan menjadi prosa nonfiksi dan prosa fiksi. Yang termasuk prosa nonfiksi yaitu biografi, autobiografi, esai, dan kritik sedangkan karya fiksi misalnya novel, cerpen, dan roman.

\section{1). Biografi dan autobiografi}

Biografi merupakan tulisan yang berupa riwayat hidup seseorang yang ditulis oleh orang lain, sedangkan autobiografi merupakan tulisan yang berisi pengalaman hidup pengarang sendiri. Contoh biografi yaitu Diponegoro yang ditulis oleh M. Yamin dan contoh autobiografi yaitu Pengalaman Masa Kecil yang ditulis oleh Nur Sutan Iskandar. 


\section{2). Kritik}

Kritik merupakan pengkajian maupun evaluasi terhadap sebuah karya sastra yang mencakup sifat yang baik maupun yang buruk, kemudian memberikan pertimbangan dan memberikan penilaian yang mantap. Contoh: Tergantung pada Kata oleh A. Teeuw.

\section{3). Esai}

Esai merupakan karangan yang membahas suatu masalah secara sepintas dari sudut pandang penulis yang tidak hanya mencakup masalah sastra, akan tetapi membahas masalah kebudayaan lainnya. Contoh: Kesusastraan Indonesia Modern dalam Kritik dan Esai oleh H.B Jassin.

\section{4). Novel}

Novel merupakan salah satu jenis prosa fiksi yang menyuguhkan nilai-nilai yang berguna bagi pembaca serta menggambarkan para tokoh, gerak dan adegan peristiwa kehidupan nyata dengan alur yang kompleks. Novel mengemukakan sesuatu secara bebas, lebih banyak, lebih rinci, lebih detail, dan lebih banyak melibatkan berbagai permasalahan yang lebih komplek. Novel berisi tentang kehidupan manusia yang fundamental, yaitu mencakup agama, masyarakat, dan individu yang di dalamnya tidak bisa luput dari konflik. Novel memiliki unsur-unsur fiksi yang saling berhubungan sehingga membentuk sebuah cerita, unsur-unsur tersebut diantaranya tema, alur, latar, tokoh, dan penokohan, sudut pandang, gaya bahasa, serta amanat. Waluyo (2002) menjelaskan ciri yang ada dalam sebuah novel yaitu a) adanya perubahan nasib dari tokoh cerita; b) 
kehidupan tokoh utamanya terdiri dari beberapa episode; c) tokoh utama biasanya tidak sampai mati.

\section{5). Cerpen}

Berdasarkan makna katanya, cerpen merupakan salah satu jenis prosa yang memiliki cerita yang relatif pendek (Sumardjo dan Saini K.M., 1994). Adapun ukuran dari jumlah kata dari cerpen kurang lebih bisa diukur dari lama waktu membaca rata-rata sebuah cerpen yaitu kurang dari satu jam. Ciri khas dari sebuah cerpen tidak menyangkut panjang pendeknya kata atau halaman akan tetapi lebih pada cakupan permasalahan yang disampaikan. Tema serta nilai kehidupan yang disampaikanpun relatif sederhana. Cerpen tidak hanya dibuat berdasarkan kisah fiktif belaka, akan tetapi bisa berupa gambaran hidup seorang pengarang atau cerita yang menyangkut masalah kehidupan orang lain yang mengandung amanat atau pesan yang hendak disampaikan kepada pembaca. Sebagaimana karya fiksi lainnya cerpen juga memiliki ciri yaitu memiliki alur tunggal, jumlah pelaku terbatas dan peristiwa yang diceritakan juga terbatas. Karakter dari tokoh yang dikisahkan biasanya langsung ditunjukkan oleh pengarang melalui dialog, narasi ataupun deskripsi. Sedangkan bentuk konflik dalam cerpen bisa bervariasi, diantaranya konflik manusia dengan dirinya sendiri atau disebut dengan konflik batin, konflik manusia dengan sesamanya, konflik manusia dengan lingkungannya, baik lingkungan ekonomi, politik, sosial, dan budaya, konflik manusia dengan Tuhan atau keyakinannya (Kosasih, 2008). Cerpen memiliki beberapa unsur pembangun dalam cerita, yaitu alur atau plot, tokoh 
dan penokohan, tema, amanat, setting, sudut pandang, dan gaya bahasa.

\section{6). Roman}

Roman merupakan suatu karangan yang terbentuk dari pengembangan kehidupan tokoh dan menceritakan kehidupan sehari-hari seorang tokoh (Jassin, 1959). Roman dibangun berdasarkan beberapa unsur yaitu alur, penokohan, serta latar. Roman seringkali disamakan dengan novel, akan tetapi keduanya memiliki perbedaan, diantaranya roman mengisahkan tokoh dan cerita yang fiktif, menceritakan kehidupan tokoh secara rinci dan mendalam. Sedangkan novel hanya fokus pada satu peristiwa penting yang terjadi pada kehidupan tokoh cerita yang pada akhirnya menimbulkan pergolakan batin dan mengubah nasib tokoh dalam cerita tersebut.

\section{Puisi}

Puisi merupakan karya sastra yang kata-katanya disusun menurut syarat tertentu dengan menggunakan irama, sajak dan terkadang menggunakan kata kiasan (Sitomorang, 1983). Puisi ditulis dalam beberapa larik dan bait dan memiliki ciri dan sifat yang khas dibandingkan karya sastra lainnya, yaitu (a) imajinatif, (b) konotatif, (c) ekspresif, (d) sugesif, dan (e) asosiatif. Imajinatif merupakan daya pikir seorang penyair untuk menggambarkan kejadian tertentu berdasarkan suatu pengalaman atau kenyataan yang dituangkan dalam karya sastra sehingga kata-kata dalam puisi seolah dapat didengar, 
dilihat, maupun dirasakan oleh pembaca. Sedangkan maksud dari konotatif merupakan bahasa ungkapan perasaan tidak mengandung arti sebenarnya. Ekspresif berarti setiap bunyi maupun kata-kata yang dituliskan oleh penyair mampu memperjelas gambaran dan menimbulkan kesan yang kuat. Sugesif berarti bahasa yang digunakan penyair dalam puisi bersifat menyarankan atau mempengaruhi pembaca secara halus. Sedangkan asosiatif berarti bahasa yang digunakan dalam puisi yang akan mampu menimbulkan pikiran dan perasaan yang mendalam bagi pembaca.

Puisi dibedakan menjadi tiga jenis yaitu puisi lama, puisi modern dan pusi kontemporer. Yang termasuk puisi lama yaitu mantera, pantun, talibun, syair, serta gurindam (Setyawati dkk, 2004). Sedangkan yang termasuk puisi modern yaitu soneta.

\section{a.Puisi Lama}

Puisi lama merupakan jenis puisi yang terikat oleh beberapa aturan yaitu jumlah baris tiap bait, jumlah suku maupun rima dan biasanya bersifat anonim. Puisi lama merupakan sastra lisan yang disampaikan secara lisan dari individu ke individu lain

\section{Mantra}

Mantra merupakan salah satu jenis puisi lama yang diciptakan oleh penganut animisme dan dinamisme. Mantra termasuk sastra lisan dan jenis sastra yang tertua yang populer di masyarakat. Mantra biasanya hanya diucapkan atau dilafalkan oleh para pawang dan dukun. Mantra biasanya 
dibacakan saat acara-acara tertentu, misalnya berburu, pengumpulan hasil hutan, serta digunakan untuk membujuk atau menolak para hantu. Mantra biasanya diucapkan dengan cara dihafal dan mampu menimbulkan kekuatan gaib untuk membantu meraih tujuan-tujuan tertentu. Secara tekstual mantra mirip dengan geguritan, hanya saja mantra hisup dalam tradisi lisan sedangkan geguritan dalam tradisi tulis. Waluyo (1991) menjelaskan bahwa mantra mempunyai beberapa ciri khas, diantaranya : (a) memiliki pilihan kata yang seksama, (b) bunyi-bunyi atau kata-katanya diulangulang yang bertujuan untuk memperkuat daya sugesti, (c) kata-kata yang digunakan kurang familiar dalam kehidupan sehari-hari, (d) kata-kata yang digunakan biasanya hanya dipahami oleh sang pawang yang ahli membaca mantra, jika mantra tersebut dibaca dengan keras akan menimbulkan efek magis. Sebagaimana karya sastra lainnya, mantra tersusun atas beberapa unsur yang terjalin secara erat dan sistematis sehingga membentuk kesatuan dan keutuhan karya sastra. Secara garis besar, struktur mantra terdiri atas enam bagian, yaitu meliputi unsur judul, unsur pembuka, unsur niat, unsur sugesti, unsur tujuan, dan unsur penutup. Unsur judul merupakan kumpulan beberapa kata yang biasanya berisitentang tujuan mantra. Pembuka mantra yaitu kata-kata yang diguankan untuk membuka mantra, kata- kata tersebut biasanya tidak mengguankan bahasa Jawa melainkan bahasa arab, misalnya bismillahirrahmanirrahim. Unsur niat merupakan frasa yang menunjukkan judl mantra atau niat dari mantra, misalnya mantra menolak balak, atau mantra pakaian yang diucapkan seorang istri supaya suami sayang kepadanya. Unsur sugesti yaitu unsur yang berisi metafora 
ataupun analogi yang dianggap memiliki kekuatan tertentu untuk membantu membangkitkan potensi kekuatan gaib pada mantra. Setiap mantra memiliki unsur sugesti yang berbedabeda. Unsur tujuan yaitu maksud yang ingin dicapai saat mengucapkan mantra. Setiap mantra memiliki tujuan yang berbeda-beda. Yang terakhir yaitu unsur penutup, merupakan unsur yang digunakan untuk menutup mantra. Biasanya menggunakan kalimat atau kata-kata sebagaimana kata-kata doa dalam Islam. Berikut merupakan contoh mantra:

\section{Mantra Menolak Bala}

Tebu item tumbuh di ruat

Selasih tumbuh di batu

Tuju tikam

Urang dak keliat

Baleik segala tuju

Bukanku maleik tuju

Allah yang meleikkan tuju

Ayam burik ayam kelabu

Ngambur ke tengah lamen

Baleik segale tuju

Baleik seneng

Berarti nyamen

\section{Pantun}

Pantun merupakan jenis puisi lama yang memiliki ciri bersajak a $b$ a $b$, tiap baitnya terdiri dari empat baris, dua baris sampiran dan dua baris isi. Sampiran merupakan dua baris pertama dalam pantun, seringkali berkaitan dengan alam yang mencirikan budaya agraris. Sampiran biasanya tidak memiliki hubungan dengan bagian kedua yang 
menyampaiakan maksud, karena hanya untuk mengantarkan rima saja. Isi dari pantun yaitu berada di dua baris terakhir. Isi pantun merupakan tujuan dari pantun tersebut (Winarni, 2010). Pantun memiliki beberapa syarat, diantaranya: (a) Terdiri atas empat baris atau larik, (b) Tiap baris pantun terdiri dari 8 hingga 12 suku kata, akan tetapi lazimnya terdiri dari 10 suku kata, (c) Baris pertama dan kedua merupakan sampiran, (d) Baris ketiga dan keempat merupakan isi dan (e) sajak akhirnya berpola a-b-a-b. Berdasarkan isinya, pantun dibedakan menjadi beberapa jenis yaitu pantun anak muda, pantun orang tua, pantun jenaka, pantun nasihat, pantun teka-teki, pantun nasib, pantun agama, pantun kepahlawanan, pantun suka-cita, dan pantun duka cita. Sedangkan dari struktur bentuknya, pantun terdiri dari pantun biasa, pantun kilat atau karmina, seloka, dan pantun berkait. Berikut merupakan beberapa contoh pantun :

a. Pantun anak muda

Memancing ikan di atas sampan

Menggali cacing jadikan umpan

Sudah lama hidup sendirian

Gadis cantik boleh dong kenalan

b. Pantun orang tua

Air pasang bulan pun terang

Hanyutlah sampan dari Jawa

Jika dating hati yang bimbang

Bagai hilang rasanya nyawa 
c. Pantun jenaka.

Pohon padi daunnya tipis

Pohon nangka berbiji lonjong

Kalau Budi suka menangis

Kalau tertawa giginya ompong

(Kosasih, 2008)

d. Pantun nasihat

Siapa suka melihat panda

Panda turun ke tanah rawa

Siapa yang malas di masa muda

Akan menyesal di hari tua

e. Pantun teka teki

Taruhlah puan di atas pati

Benang sutra dilipat jangan

Kalu tuan bijak bestari

Binatang apa susu delapan

f. Pantun nasib

Seiring nada irama bepadu

Lagu tentang kisah seorang

Sungguh dinda sangat rindu

Rindu abang jauh di seberang

g. Pantun agama

Tubuh dijirat paduka tuan

Tidak cacat tidak selia

Didalam surga ada penantian 
Hanya untuk yang beramal mulia

h. Pantun kepahlawanan

Pergi ke Medan labuhan Belawan

Membawa peti berisi gelas

Selamat jalan para pahlawan

Pengorbananmu tak terbatas

\section{Talibun}

Talibun merupakan karya sastra yang terdiri atas sampiran dan isi. Talibun hampir sama dengan pantun, akan tetapi talibun memiliki larik lebih dari empat dan selalu genap, misalnya enam, delapan, sepuluh, dua belas, atau empat belas (Setyawati, 2004).

\section{Contoh Talibun 8 Baris}

Talibun delapan baris

Kalau anak pergi ke pekan

Yu beli belanak beli I kan panjang beli dahulu

Kalau anak pergi berjalan I bu cari sanak pun cari

Induk semang cari dahulu

Pasir bulan dalam perahu

Berlabuh tentang batu bara

Berkiawan lalu ke tepian

Ketika menghadap kemudinya

Kasih tuan hambalah tahu

Bagai orang menggenggam bara

Rasa hangat dilepaskan

Begitu benar malah kiranya

(Kosasih, 2008) 


\section{Syair}

Syair merupakan bentuk puisi klasik dan merupakan pengaruh kebudayaan Arab. Kosasih (2008) menjelaskan bahwa syair memiliki ciri-ciri sebagai berikut:

1) Terdiri dari empat baris;

2) Tiap baris terdiri dari 8 sampai 10 suku kata;

3) Tidak memiliki sampiran dan isi (semuanya merupakan isi);

4) Berima akhir a-a-a-a

Contoh syair

Lalulah berjalan

Ken Tambuhan diiringkan penglipur dengan tadahan

Lemah lembut berjalan perlahan-lahan

Lakunya manis memberi kasihan.

(Kosasih, 2008)

\section{Gurindam}

Gurindam merupakan salah satu jenis puisi yang berupa nasihat yang terdiri atas dua baris, memilki irama a a, kedua barisnya merupakan isi, baris pertama merupakan sebab, sedangkan baris kedua adalah akibat. isinya berupa nasihat (Setyawati, 2004). Contoh gurindam yang terkenal ialah kumpulan gurindam karangan pujangga Melayu klasik Raja Ali Haji dengan nama "Gurindam Dua Belas". Gurindam tersebut terdiri atas dua belas pasal dan berisi kurang lebih 64 buah gurindam.

a. Awal diingat akhir tidak Alamat badan akan rusak Barang siapa mengenal dua Tahulah dia barang terpedaya 
b. Mengumpat dan memuji hendaklah pikir

Di situlah banyak orang tergelincir

c. Barang siapa meninggalkan sembahyang

Seperti rumah takbertian

d. Jika hendak mengenal orang berbangsa

Lihat kepada budi dan bahasa

e. Apabila anak tidak dilatih

Jika besar ibu-bapaknya letih

(Kosasih, 2008)

6. Pantun Berkait / seloka

Pantun berkait atau disebut juga dengan pantun berantai merupakan pantun yang terdiri atas beberapa bait yang sambung-menyambung. Baris kedua dan keempat dari bait yang pertama dipakai lagi pada baris pertama dari ketiga pada bait kedua. Demikianlah juga hubungan antara bait kedua dan ketiga, ketiga dan keempat, dan seterusnya. Contoh:

Sarang garuda di pohon beringin

Buah kemuning di dalam puan

Sepucuk surat dilayangkan angin

Putih kuning sambutlah Tuan

Buah kemuning di dalam puan

Dibawa dari Indragiri

Putih kuning sambutlah

Tuan Sambutlah dengan si tangan kiri

Dibawa dari Indragiri

Kabu-kabu dalam perahu 
Sambutlah dengan si tangan kiri

Seorang mahluk janganlah tahu.

(Kosasih, 2008)

1. Peribahasa

Peribahasa merupakan kumpulan kalimat atau perkataan yang memiliki susunan yang tetap dan mengandung maksud tertentu. Peribahasa merupakan salah satu contoh karya sastra klasik dan masih bisa dijumpai dalam kehidupan masyarakat saat ini. Ditinjau dari segi isi, peribahasa dapat dibedakan menjadi beberapa jenis, yaitu:

(a) Nasihat.

Peribahasa nasihat berisi tentang masukan positif atau saran agar orang yang dinasihati dapat introspeksi diri sehingga mampu merubah tingkah lakunya tanpa merasa tersinggung. Contoh: "Kalah jadi abu, menang jadi arang."

Peribahasa ini diperuntukkan bagi orang yang bersengketa agar segera berdamai. Baik yang kalah maupun yang menang akan tetap mendapat kesusahan, oleh karena itu, lebih baik berdamai saja.

(b) Sindiran

Peribahasa sindiran digunakan untuk mengingatkan atau menyadarkan seseorang dengan tidak melukai hati nya.peribahasa sindiran ini diungkapkan secara tidak langsung, sedangkan peribahasa nasihat diungkapkan secara jelas (bagaimana seharusnya). Contoh: Menjilat air ludah

Peribahasa tersebut merupakan sindiran bagi orang yang suka mencaci-maki tanpa pertimbangan yang dalam, kemudian memujinya lagi. 
(c) Pujian

Peribahasa ini digunakan untuk memuji dan menggunakan bahasa yang halus, enak didengar dna diplomatis. Contoh: Bagai aur dengan tebing, merupakan peribahasa pujian kepada dua sahabat yang selalu akur.

\section{b. Puisi Baru}

Puisi baru merupakan jenis puisi yang lebih bebas dari pada puisi lama, baik dari segi jumlah baris, suku kata, maupun rima. Di antara jenis puisi baru yaitu soneta. Soneta merupakan puisi yang terdiri dari empat belas baris. Empat bait dibangun oleh dua quatrain dan dua terzina. Dua quatrain merupakan sampiran dan merupakan satu kesatuan yang disebut oktaf, sedangkan dua terzina merupakan isi dan merupakan satu kesatuan yang disebut sextet. Bagian sampiran dari soneta biasanya berupa gambaran alam, sedangkan sextet berisi tentang curahan atau jawaban atau simpulan dari apa yang dilukiskan dalam octav. Berikut merupakan contoh soneta

\section{Gembala}

Perasaan siapa takkan nyala (a)

Melihat anak berelagu dendang(b)

Seorang saja ditengah padang(b)

Tiada berbaju buka kepala (a)

Beginilah nasib anak gembala (a)

Berteduh dibawah kayu nan rindang (b)

Semenjak pagi meninggalkan kandang (b)

Pulang kerumah di senja kala (a) 
Jauh sedikit sesayup sampai (a)

Terdengar olehku bunyi serunai (a)

Melagukan alam nan molek permai (a)

Wahai gembala di segara hijau (c)

Mendengarkan puputmu menurutkan kerbau (c)

Maulah aku menurutkan dikau (c)

\section{c. Puisi kontemporer}

Puisi kontemporer merupakan puisi yang lahir dalam kurun waktu terakhir, biasanya kurang memperhatikan aspek kesantunan berbahasa (menggunakan bahasa ejekan dan sindiran). Puisi kontemporer tidak terlalu memperhatikan kata-kata simbolik atau lambang intuisi, gaya bahasa, irama, dan sebagainya karena dianggap tidak begitu penting lagi.

Apabila dilihat dari cara penyair mengungkapkan isi atau gagasannya, puisi dibagi menjadi tiga jenis: puisi naratif, puisi lirik, dan puisi deskriptif.

1) Puisi naratif

Puisi naratif merupakan puisi yang berisi tentang ungkapan cerita atau penjelasan penyair. Puisi naratif terdiri dari dua jenis yaitu balada (cerita tentang orang-orang perkasa atau tokoh pujaan) dan romansa (puisi cerita yang menggunakan bahasa romantis yang berkisah tentang percintaan dan diselingi oleh perkelahian dan petualangan). Contoh puisi naratif yaitu Balada Orang-orang Tercinta karya WS Rendra. 
2) Puisi lirik

Puisi lirik merupakan puisi yang digunakan untuk mengungkapkan gagasan pribadi dari penyairnya. Puisi lirik digolongkan menjadi beberapa jenis, yaitu elegi, ode, dan serenada (Waluyo, 1991). Elegi merupakan jenis puisi lirik yang berisi tentang unkapan duka dari seorang penyair, misalnya "Buah Rindu" karya Amir Hamzah. Ode merupakan jenis puisi lirik yang berisi tentang pujian terhadap seseorang (pahlawan), pujian terhadap suatu hal ataupun keadaan, contoh Ode yang sangat terkenal yaitu "Teratai" karya Sanusi Pane dan "Ode Buat Proklamator" karya Leon Agusta. Sedangkan serenade yaitu jenis puisi lirik yang menggambarkan suasana senang, misalnya Serenada Merah Padam karya W.S. Rendra. Berikut merupakan contoh Ode.

\section{Ode Buat Proklamator}

Bertahun setelah kepergiannya kurindukan dia kembali Dengan gelombang semangat halilintar dilahirkan sebuah negeri; dalam lumpur dan lumut, dengan api menyapu kelam menjadi untaian permata hijau di bentangan cahaya abadi;

yang senantiasa membuatnya tak pernah berhenti bermimpi menguak kabut mendung, menerjang benteng demi benteng membalikkan arah topan, menjelmakan impian demi impian Dengan seorang sahabatnya, mereka tandatangani naskah itu Mereka memancang tiang bendera, merobah nama dan peta, 
berjaga membacakan sejarah, mengganti bahasa pada buku. Lalu dia meniup terompet dengan selaksa noda kebangkitan sukma

Kini kita ikut membubuhkan nama di atas bengkalainya; meruntuhkan sambil mencari, daftar mimpi membelit bulan perang saudara mengundang musnah, dendam tidur di hutan hutan, di sawah terbuka yang sakti Kata berpasir di bibir pantai hitam dan oh, lidahku yang teriepit, buih lenyap di laut biru derap suara yang gempita cuma bertahan atau menerkam

$Y a$, walau tak mudah, kurindukan semangatnya menyanyi kembali bersama gemuruh cinta yang membangunkan sejuta rajawali

Tak mengelak dalam bercumbu, biar berbisa perih dirabu Berlapis cemas menggunung sesal mutiara matanya yang pudar

Bagi negeriku, bermimpi di bawah bayangan burung garuda.

(Kosasih, 2008)

3) Puisi deskriptif

Puisi deskriptif merupakan jenis puisi yang menggambarkan kesan penyair terhadap suatu hal, benda, ataupun keadaan yang menarik perhatiannya (Kosasih, 2008). Dalam hal ini puisi deskriptif disajikan oleh penyair melalui kritikan atau sindiran. Contoh puisi deskriptif yaitu puisi yang berisi kritik sosial, ironi, puisi impresionistik dan satire. Puisi 
kritik sosial yaitu puisi yang berisi tentang perasaan tidak senang seorang penyair terhadap seseorang ataupun keadaan. Penyair mengungkapkan perasaan tersebut dengan cara membeberkan ketidakberesan suatu keadaan atau orang yang dikritiknya. Puisi impresionistik yaitu puisi yang menggambarkan kesan seorang penyair terhadap suatu hal. Sedangkan satire yaitu puisi yang berisi tentang ungkapan ketidakpuasan seorang penyair terhadap suatu hal atau keadaan. Ungkapan tersebut dinyatakan dengan cara menyindir. Berikut merupakan contoh satire:

\section{GURINDAM EMPAT}

Karya : Taufik Ismail.

Ayahmu kaya raya berbagai rupa caranya

Mengapa engkau bangga Cuma menumpang nama

Pamanmu generasi komisi angkatan pertama Engkau dan ponakanmu generasi komisi I dan III Silsilah dan wajah jelas bukan preman pasar

Tapi praktek bisnismu sunyi akhlak begitu kasar Jembatan ditelan, kapal diuntal, proyek habis dikunyah 100 keluarga kenyangnya tereng (Suryaman \& Wiyatmi, 2013)

6. Drama

Drama merupakan karya sastra yang berisi tentang kehidupan dan dipertunjukkan dalam bentuk action dan 
dialog (Supriyadi, 2006). Hal yang terpenting dalam suatu drama yaitu dialog, karena dialog yang terjadi di atas panggung menentukan isi dari cerita suatu drama. Drama memiliki beberapa perbedaan dengan karya sastra lain, misalnya puisi dan prosa, perbedaan tersebut terletak pada tujuan penulisan naskah. Naskah drama ditulis dengan tujuan utamanya untuk dipertunjukkan, sedangkan naskah prosa dan puisi ditulis untuk dibaca dan dihayati. Menurut Waluyo (2002) drama dikelompokkan menjadi beberapa jenis yaitu (1) tragedy / drama duka, yaitu drama yang menggambarkan kisah sedih dari tokoh cerita, bersifat serius, memunculkan rasa kasihan dan ketakutan, serta menampilkan tokoh yang bersifat kepahlawanan. (2) melodrama, yaitu cerita yang sentimental, dan mengharukan, (3) komedi, yaitu drama yang berisi dialog candaan dan bersifat menghibur penonton, terkadang ada unsur sindiran, (4) dagelan, yaitu drama yang berisi tentang dialog candaan yang menghibur. Bahasa yang digunakan biasanya cenderung kasar dan fulgar.

Pada dasarnya, naskah drama dibagi menjadi beberapa babak. Dalam satu babak dibagi menjadi beberapa adegan. Apabila dalam satu drama terdiri dari satu babak, maka drama tersebut disebut sebagai drama satu babak atau drama pendek. Sedangkan drama yang terdiri dari tiga atau lima babak disebut sebagai drama panjang (Sumardjo \& Saini, 1986).

Wiyanto (2002) menjelaskan bahwa drama terdiri dari beberapa unsur yang mendukung sehingga dapat membangun cerita yaitu tema, alur atau plot, latar dan waktu, tokoh, gaya bahasa, amanat, dan dialog. 


\section{a. Tema}

Tema merupakan intisari sebuah cerita yang diungkapkan oleh pengarang. Dalam suatu drama tema akan dikembangkan menjadi cerita kemudian dibagi menjadi beberapa adegan dan babak. Babak pertama dalam suatu drama merupakan pembukaan, yang berisi tentang beberapa hal yang berkaitan dengan waktu, tempat, dan beberapa tokoh yang terlibat dalam sebuah drama. Babak kedua merupakan munculnya beberapa konflik. Babak ketiga merupakan puncak dari konflik yang terjadi dalam suatu cerita. Babak ke empat merupakan penyelesaian konflik, dan babak kelima merupakan ending dari sebuah cerita, apakah nasib tokoh berakhir bahagia atau sebaliknya.

b. Alur

Alur merupakan rangkaian peristiwa yang saling berkaitan dan menunjukkan hubungan sebab akibat. Dalam suatu drama, alur dibedakan menjadi dua jenis, yaitu alur konvensional dan alur nonkonvensional. Alur konvensional yaitu alur yang menyajikan suatu peristiwa secara urut, peristiwa tersebut terjadi sehingga mengakibatkan terjadinya peristiwa lainnya. Sedangkan alur nonkonvensional yaitu alur yang menyajikan suatu peristiwa secara tidak runtut.

\section{c. Latar dan waktu}

Latar merupakan tempat dan waktu terjadinya peristiwa dalam sebuah cerita. Latar biasanya dibuat selogis mungkin disesuaikan dengan jenis drama yang dipentaskan.

\section{d. Tokoh}

Tokoh dalam suatu drama tidak hanya berupa manusia, akan tetapi juga bisa berupa hewan atau tumbuhan. Tokoh dalam drama dibedakan menjadi tiga jenis yaitu protagonist, 
antagonis, dan tritagonis. Pemilihan tokoh dalam drama merupakan hal yang sangat penting, karena berkaitan dengan aspek penjiwaan. Para tokoh harus menguasai isi naskah drama dan menjiwai peranannya agar para penonton bisa mengerti apa yang disampaikan dalam drama tersebut. Menurut Kosasih (2008) tokoh-tokoh dalam drama dibedakan menjadi empat kelomok, yaitu (1) tokoh Gagal atau Tokoh Badut (The Foil), yaitu tokoh yang pendiriannya bertentangan dengan tokoh lain. Kehadiran tokoh ini berfungsi untuk menegaskan tokoh lain, (2) tokoh Idaman (The Type Character), yaitu tokoh yang berperan sebagai pahlawan dengan karakternya yang gagah, adil, atau terpuji, (3) tokoh Statis (The Static Character) yaitu tokoh yang memiliki peran yang sama, tanpa ada perubahan dari awal hingga akhir cerita, (4) tokoh yang berkembang, yaitu tokoh yang mengalami perkembangan selama cerita berlangsung.

e. Gaya Bahasa

Gaya bahasa yang digunakan dalam cerita drama hendaknya menarik dan disesuaikan dengan tema serta watak tokoh yang ada. Penggunaan gaya bahasa juga sangat menentukan kualitas sebuah cerita. Gaya bahasa bisa berupa pertentangan, penegasan, sindiran, dan perbandingan.

\section{f. Amanat}

Amanat merupakan pesan moral yang disampaikan oleh pengarang melalui sebuah cerita. Pesan moral yang dalam sebuah cerita tidak disampaiakan secara langsung oleh penulis, akan tetapi penonton bisa menyimpulkan sendiri apa pesan moral yang hendak disampaikan dalam sebuah cerita.

g. Dialog 
Dialog merupakan percakapan yang terjadi antara dua orang atau lebih. Dialog yang diperankan harus disesuaikan dengan karakter dari tokoh cerita, dengan kata lain dialog mampu menunjang gerak laku tokohnya. Disamping itu, dialog yang diucapkan di atas pentas harus lebih tajam dan tertib daripada ujaran sehari-hari, dan yang paling penting adalah dialog disampaikan secara wajar dan alamiah.

\section{RESENSI KARYA SASTRA (NOVEL DAN CERPEN)}

Resensi merupakan tulisan yang berisi tentang tinjauan terhadap kualitas sebuah buku. Resensi dilakukan agar para pembaca berminat membaca buku ynag dibahas atau di resensi, selain itu resensi bertujuan untuk memandu pambaca dalam memahami buku tersebut. Gaya bahasa yang digunakan dalam meresensi buku umumnya menggunakan bahasa persuasif. Beberapa hal yang dicantumkan dalam meresensi buku atau karya sastra diantaranya identitas biku, pengarang, ringkasan buku/ karya sastra serta penilaian terhadap kelebihan dan kelemahan buku / karya sastra.

Beberapa aspek yang dinilai dalam meresensi buku / karya sastra mencakup aspek organisasi da nisi penulisannya. Yang dimaksud dengan organisasi (dalam novel) yaitu alur, penokohan, latar amanat, serta tema. Kemudian dari unsur bahasa mencakup struktur kalimat, gaya bahasa, diksi, serta hubungan antar kalimat. Selain itu hal lain yang tidak kalah penting yaitu mengenai layout dan pencetakannya (kesalahankesalahan pencetakan, tanda baca, mencetak kata, dan sebagainya) karena beberapa kesalahan tersebut dapat mengganggu kenyamanan pembaca. 
Adapun kangkah-langkah dalam meresensi sebuah karya sastra menurut Kosasih (2008) adalah sebagai berikut:

1. Membaca dan memahami isi karya sastra. Pemehaman terhadap isi karya sastra bertujuan agar penulis resensi lebih mudah dalam memberikan tanggapan terhadap karya sastra

2. Membuat ringkasan dengan menggunakan bahasa sendiri. Ringkasan yang dibuat secara umum, tidak perlu terlalu rinci.

3. Membuat penilaian yang mencakup kelebihan dan kelemahan karya sastra dengan disertai alasan dan contoh.

Berikut merupakan contoh resensi novel Oleh Pretty Himmatunnisa dalam Mizan Online (Kosasih, 2008):

\section{Misteri Burung Merah}

Sukses dengan novelnya yang berjudul Perjalanan Dua Purnama, Sharon Creech mencoba untuk menciptakan novel berikutnya yang tidak kalah dengan judul Misteri Burung Merah. Dalam novelnya kali ini Sharon Creech menghadirkan perpaduan yang indah antara humor, kasih sayang, dan filosofi sederhana. Misteri Burung Merah karya Sharon Creech ini menceritakan tentang petualangan seorang remaja bernama Zinnia Taylor, 14 tahun, yang memiliki keluarga besar. Mereka terdiri dari ayah-ibu, 3 saudara perempuan Gretchen, May dan Bonnie, 3 saudara laki-laki Will, Ben dan Sam, serta Paman Nate dan Bibi Jessie--karena rambutnya yang merah maka Pam Nate menjulukinya si Burung Merah. Zinnia Taylor menjadi lebih dekat dengan 
keluarga Paman Nate dibandingkan dengan keluarganya sendiri sejak Rose anak tunggal Paman Nate meninggal pada usia 4 tahun karena menderita batuk rejan. Mereka tinggal di sebuah kota bernama Bybanks yang sebagian besar berupa daerah pertanian.

Pada suatu musim semi, Zinny--panggilan dari Z innia Taylor-menemukan jalan setapak di belakang rumahnya. Pada saat pertama kali Zinny menemukan jalan setapak itu, Paman Nate dan Bibi Jessie terlihat seolah mengetahui sesuatu tentang jalan menuju perbukitan itu dan mereka tak ingin orang lain menemukannya. Zinny pun berusaha untuk membersihkan jalan setapak yang telah ditumbuhi rumput dan semak liar itu setelah ia mempelajari di museum bahwa jalan ini adalah jalur Bybanks-Chocton ratusan tahun yang lalu. Nama-nama tempat yang dilalui oleh jalan setapak itu pada peta di museum terdengar menakjubkan dan aneh seperti Jalan Dara, Lembah Gagak, Bukit Jari Bayi, Bukit Berunang Ngantuk, bahkan Lembah Hantu dan Bukit Bayangan Kematian justru terdengar menakutkan.

Misteri dalam novel ini dimulai ketika tiba saat kematian Bibi Jessie yang terjadi setelah Zinny memperlihatkan sebuah medali dan ular yang ditemukannya pada jalan setapak. Seluruh keluarga Zinny, terlebih lagi Paman Nate merasa sangat kehilangan atas kematian Bibi Jessie. Zinny merasa sangat bersalah karena tidak seharusnya ia memperlihatkan ular yang ditemukannya pada Bibi Jessie karena Bibi Jessie sangat takut pada ular meskipun dokter mengatakan bahwa kematiannya karena diabetes.

Sejak saat itu pula Paman Nate memiliki kebiasaan aneh, berkeliaran, memotret, berbicara pada diri sendiri dan 
kepada orang tak tampak. Salah satunya adalah Bibi Jessie, Si Burung Merahnya, dan ia menghabiskan sebagian besar waktunya untuk mencoba menangkapnya. Terkadang ia terlihat berkeliaran ke arah padang rumput serta perbukitan di sekitar jalan setapak sambil membawa sebatang tongkat untuk memukul apa saja yang mirip dengan ular karena Bibi Jessie paling takut terhadap ular. Zinny pun bertekad menyingkap seluruh jalan setapaknya untuk mengungkap misteri di balik jalan setapak itu yang mungkin berhubungan dengan $\mathrm{Si}$ Burung Merah, Bibi Jessie.

Meskipun novel ini termasuk dalam kategori fi ksi misteri, namun bahasa yang digunakan dalam novel ini terkesan ringan dan mudah untuk dinikmati terlepas dari kesan serius yang biasa dibangun pada novel novel misteri detektif. Bahkan, novel ini dipenuhi dengan humor-humor ringan yang menjadi lucu karena sikap yang diambil o leh pelakunya adalah apa adanya.

Hal yang menarik adalah pertanyaan yang selalu diajukan penghuni Bybanks setiap kali bertemu keluarga Taylor, "Kamu Taylor yang mana?" Pertanyaan tersebut kerap kali muncul karena jarak usia antara Zinny dan saudarasaudaranya terlalu dekat sehingga membuat mereka sulit untuk dibedakan. Sampai-sampai seseorang menyarankan ibu Zinny untuk melakukan KB.

Lama kelamaan Zinny dan saudara-saudaranya menjadi bosan untuk menjelaskan Taylor yang mana mereka pada setiap orang, terlebih pada ayah ibu mereka. Mereka pun mencari cara agar orang lain dapat membedakan mereka dengan mudah dan tepat. Gretchen pun selalu memakai baju hijau (Green), May menggunakan pita multiwarna, Zinny 
melukiskan bunga zinnia pada semua pakaiannya, Bonnie mengenakan pita warna biru (Blue), Will hanya memakan makanan serba putih (White), Ben menjadikan buncis (Bean) sebagai menu tetapnya, dan Sam memilih sop. Namun usahausaha ini terkadang sia-sia karena masih saja ada orang yang salah dalam membedakan mereka.

Hal menarik lainnya juga terlihat pada usaha keras Jake untuk mendekati Zinny yang selalu disalahartikan oleh Zinny sebagai usaha Jake mendekati May dengan perantara Zinny. Pikiran itu muncul karena Zinny merasa bahwa ia sudah sering kali ditipu oleh cowok-cowok yang menyuapnya dengan banyak hadiah hanya untuk mendapatkan May. Selain penuh dengan humor, novel ini juga dilengkapi dengan fi losofi fi losofi sederhana seperti "Hidup adalah semangkuk spageti, di dalamnya engkau bisa mendapatkan bakso daging" serta "Bahkan monyetpun bisa jatuh dari pohon" yang disulam oleh Bibi Jessie sebagai hiasan dinding.

Sebagai novel yang juga menghadirkan sentuhan kasih sayang dalam keluarga dalam kisahnya, agaknya novel ini sangat cocok untuk dinikmati anak-anak hingga remaja bahkan oleh dewasa sekalipun. Novel ini sendiri dibagi dalam 46 bagian, di mana setiap bagiannya memiliki judul sehingga tidak akan terasa membosankan ketika membacanya.

Keluarga besar Taylor dalam novel ini diciptakan oleh Sharon Creech karena terilhami oleh keluarganya sendiri yang juga merupakan keluarga besar. Sedangkan Bybanks itu sendiri terinspirasi dari kota Quincy, Kentucky, tempat sepupu Sharon Creech tinggal di sebuah pertanian.

Kekuatan novel ini terletak pada pembentukan karakter tokohnya yang kuat, juga terletak pada penggunaan 
bahasanya yang simpel namun padat. Sebagai novel terjemahan, hasil penerjemahan novel ini ke dalam bahasa Indonesia juga patut diacungi jempol karena mampu mempertahankan kekuatan pemilihan kata dalam bahasa Indonesia yang biasa lebih bertele-tele dalam bahasa Inggris.

\section{E. RANGKUMAN}

a.Berdasarkan jenis bahasa maupun isinya, jenis (genre) sastra dikelompokkan menjadi dua yaitu sastra imajinatif dan sastra non imajinatif

b.Karya sastra imajinatif merupakan jenis karya sastra yang ditulis berdasarkan hasil khayalan penulis, akan tetapi masuk akal dan mengandung kebenaran yang mendramatisasikan hubungan antar manusia.

c. Sastra non-imajinatif merupakan sebuah karya sastra yang lebih menonjolkan unsur fakta dari pada unsur khayalan.

d.Unsur intrinsik sebuah karya sastra mencakup alur atau plot, tokoh, tema, latar atau setting, sudut pandang, bahasa atau gaya bahasa.

e. Setting merupakan tempat, hubungan waktu, dan lingkungan sosial tempat terjadinya peristiwa yang diceritakan.

f. Tema merupakan ide yang mendasari sebuah cerita sehingga oleh pengarang dijadikan sebagai pangkal untuk memaparkan karya fiksi yang diciptakannya.

g. Gaya bahasa merupakan cara yang digunakan oleh pengarang untuk membangun estetika dalam sebuah cerita.

h.Sudut pandang merupakan cara seorang pengarang dalam menampilkan para pelaku di dalam sebuah cerita.

i. Alur merupakan rangkaian cerita yang dibentuk oleh tahapan-tahapan peristiwa yang saling berkaitan sehingga menjadi sebuah cerita. 
j. Amanat merupakan ajaran moral atau pesan yang ingin disampaikan oleh pengarang kepada pembaca baik secara eksplisit maupun implisit.

k.Unsur ekstrinsik merupakan segala faktor yang melatarbelakangi penciptaan sebuah karya sastra.

1. Struktur fisik puisi meliputi beberapa unsur, diantaranya:

- Perwajahan / tipografi puisi

- Diksi atau pilihan kata.

- Pengimajian

- Kata konkrit

- Bahasa figurative atau disebut dengan majas

- Verifikasi yang meliputi rima dan ritma

- Bahasa Figuratif (Majas)

m. Prosa merupakan karya naratif yang bersifat fiksi yang berarti hanya sebuah imajinasi atau rekaan.

n. Beberapa contoh prosa lama yaitu hikayat, dongeng, mite, legenda, fabel, dan sebagainya.

o. Biografi merupakan tulisan yang berupa riwayat hidup seseorang yang ditulis oleh orang lain.

p. Autobiografi merupakan tulisan yang berisi pengalaman hidup pengarang sendiri.

q. Kritik merupakan pengkajian maupun evaluasi terhadap sebuah karya sastra yang mencakup sifat yang baik maupun yang buruk, kemudian memberikan pertimbangan dan memberikan penilaian yang mantap.

r. Esai merupakan karangan yang membahas suatu masalah secara sepintas dari sudut pandang penulis yang tidak hanya mencakup masalah sastra, akan tetapi membahas masalah kebudayaan lainnya.

s. Novel merupakan salah satu jenis prosa fiksi yang menyuguhkan nilai-nilai yang berguna bagi pembaca serta 
menggambarkan para tokoh, gerak dan adegan peristiwa kehidupan nyata dengan alur yang kompleks.

t. Roman merupakan suatu karangan yang terbentuk dari pengembangan kehidupan tokoh dan menceritakan kehidupan sehari-hari seorang tokoh.

u. Puisi dibedakan menjadi tiga jenis yaitu puisi lama, puisi modern dan pusi kontemporer.

v. Yang termasuk puisi lama yaitu mantera, pantun, talibun, syair, serta gurindam.

w. Mantra merupakan salah satu jenis puisi lama yang diciptakan oleh penganut animisme dan dinamisme.

x. Talibun merupakan karya sastra yang terdiri atas sampiran dan isi.

y. Syair memiliki ciri-ciri sebagai berikut:

- Terdiri dari empat baris

- Tiap baris terdiri dari 8 sampai 10 suku kata

- Tidak memiliki sampiran dan isi (semuanya merupakan isi)

- Berima akhir a-a-a-a

z. Gurindam merupakan salah satu jenis puisi yang berupa nasihat yang terdiri atas dua baris, memilki irama a a, kedua barisnya merupakan isi, baris pertama merupakan sebab, sedangkan baris kedua adalah akibat. isinya berupa nasihat.

\section{E.SOAL EVALUASI}

1. Jelaskan perbedaan antara sastra imajinatif dan sastra nonimajinatif!

2. Jelaskan perbedaan antara metode showing dan metode telling! 
3. Jelaskan bagaiamana cara agar pembaca bisa memahami watak tokoh dalam sebuah cerita!

4. Buatlah masing-masing satu contoh pantun jenaka, pantun nasihat, pantun teka-teki, pantun nasib, dan pantun agama!

5. Buatlah masing-masing satu contoh dari puisi baru dan cerpen!

6. Carilah salah satu puisi karya penyair tertentu. Analisislah puisi tersebut berdasarkan unsur fisiknya !

7. Bacalah masing-masing satu cerpen atau novel angkatan Pujangga Baru dan Balai Pustaka, kemudian buatlah analisis unsur intrinsik dan ekstrinsiknya!

8. Pilihlah salah satu judul novel dan cerpen kemudian buatlah resensi dari karya tersebut! 


\section{BAB IX}

\section{APRESIASI SASTRA}

\section{Tujuan Instruksional :}

Mahasiswa mampu menguasai konsep teoritis tentang apresiasi sastra

\section{A. PENGERTIAN APRESIASI SASTRA}

Apresiasi berasal dari kata apreciatio (Bahasa Latin) yang berarti mengindahkan atau menghargai. Pengertian apresiasi sastra banyak dijelaskan oleh beberapa ahli diantaranya, Gove (dalam Aminudin, 2014) istilah apresiasi mempunyai makna pengenalan melaui perasaan batin dan pemahaman atau pengakuan terhadap nilai keindahan yang diungkapkan oleh pengarang. Selain itu, Effendi (1973) mendefinisikan apresiasi sebagai kegiatan menggauli karya sastra secara dengan sungguh-sungguh sehingga mampu menumbuhkan pengertian, penghargaan, kepekaan pikiran kritis dan perasaan yang baik terhadap sebuah karya sastra. Dari dua pengertian tersebut dapat disimpulkan bahwa apresiasi sastra merupakan kegiatan membaca, memahami, menikmati, mengevaluasi karya sastra baik sastra yang berupa teks maupun pertunjukan secara langsung. Kegiatan apresiasi sastra secara langsung misalnya bisa dilakukan dengan melihat, mengenal, memahami, menikmati, memberikan penilaian terhadap kegiatan pertunjukan membaca puisi, drama, baik pementasan di televisi, radio, maupun pertunjukan secara langsung. Sedangkan apresiasi sastra secara tidak langsung bisa dilakukan dengan mempelajari teori sastra, mempelajari sejarah sastra, 
membaca artikel yang berhubungan dengan karya sastra, membaca buku atau esei yang memberikan penilaian terhadap karya sastra. Sedangkan menurut Saryono (2009) apresiasi sastra merupakan kegiatan pengindahan, penikmatan, penjiwaan, serta penghayatan karya sastra secara individual maupun momentan, subjektif, eksistensial, rohaniah,khusuk serta total sehingga dapat memperoleh sesuatu agar kepedulian, kepekaan, kecintaan, serta ketajaman terhadap karya sastra mampu tumbuh dan berkembang.

Squire dan Taba (dalam Aminudin, 2014) menjelaskan bahwa apresiasi melibatkan tiga unsur inti yaitu aspek kognitif, aspek amotif, dan aspek evaluatif. Aspek kognitif yaitu berkaitan dengan intelek pembaca dalam memahami unsur sastra yang bersifat obyektif baik yang berhubungan dengan unsur intrinsik maupun ekstrinsik sebuah karya sastra. Unsur intrinsik sastra yang bersifat obyektif misalnya mencakup tulisan, aspek bahasa, serta struktur wacana yang berhubungan dengan makna yang tersurat. Sedangkan unsur ekstrinsik sastra mencakup biografi pengarang, latar proses penciptaan karya sastra, latar belakang sosial budaya yang menunjang kehadiran suatu teks sastra. Aspek emotif yaitu berkaitan dengan keterlibatan unsur emosi pembaca dalam menghayati keindahan suatu sastra. Dalam hal ini,unsur emosi juga memiliki peranan penting dalam memahami unsur yang sifatnya subyektif. Unsur subyektif tersebut berupa bahasa yang dipaparkan dan mengandung makna konotatif interpretatif serta unsur-unsur lainnya misalnya penampilan tokoh dan setting yang sifatnya metaforis. Sedangkan 
aspek evaluatif yaitu berhubungan dengan kegiatan memberikan penilaian terhadap baik buruk, keindahan, kesesuaian dalam suatu sastra. Aspek evaluatif ini tidak harus berupa karya kritik akan tetapi secara personal dimiliki oleh pembaca.

\section{B. FUNGSI APRESIASI SASTRA}

Fungsi apresiasi sastra sangat erat kaitannya dengan tujuan apresiasi sastra yaitu menyuguhkan pengalaman, pengetahuan, kesadaran serta hiburan. Agar tujuan tersebut tercapai maka fungsi sastra harus disesuaikan pula. Menurut Saryono (2009) apresiasi sastra memiliki beberapa fungsi diantaranya fungsi eksperensial, fungsi informasional, fungsi penyadaran, dan fungsi rekreatif. Masing-masing fungsi tersebut dijelaskan sebagai berikut:

a.Fungsi eksperensial

Yang dimaksud dengan fungsi eksperensial yaitu menyuguhkan, menawarkan, serta menyediakan pengalaman manusia kepada pelaku apresiasi sastra agar mampu menjiwai, menghayati dan menikmati pengalamanpengalaman tersebut sebagai bahan perenungan. Adapun pengalaman-pengalaman yang dapat dinikmati atau diambil oleh pelaku apresiasi sastra terbatas pada pengalaman-pengalaman yang umumnya diperoleh manusia, misalnya pengalaman moral, humanistis, psikologis,filosofis, religius-sufistis, magis-mistis, sosial budaya, sosial politis, dan sebagainya. Proses perenungan makna pada saat mengapresiasi karya sastra sepenuhnya bergantung pada ketajaman nurani, rasa,kadar penjiwaan, penghayatan, serta budi pelaku apresiasi sastra. 
b. Fungsi informatif

Fungsi informatif yaitu menyediakan, menawarkan, serta menyuguhkan pengetahuan agar pengetahuan tersebut dapat dijiwai, dihayati, dan dinikmati oleh pelaku apresiasi sastra. Adapun pengetahuan yang dapat diambil oleh pelaku apresiasi sastra hanyalah pengetahuan yang sifatnya lumrah atau umum, misalnya moral, psikologis, filosofis, sossial budaya, sosial politis, dan sebagainya. Proses pemerolehan pengetahuan pada karya sastra bergantung pada kedar penjiwaan, nurani, penghayatan, serta budi pelaku apresiasi sastra.

c. Fungsi penyadaran

Fungsi penyadaran dalam apresiasi sastra maksudnya fungsi menyediakan, menawarkan, menghidangkan beberapa sinyal kesadaran kepada pelaku apresiasi sastra agar mampu menyadari beberapa hal misalnya hakikat kehidupan, tanggungjawab manusia, kewajiban manusia, kebebasan hidup, dan sebagainya. Adapun sinyal-sinyal kesadaran yang disajikan dalam sebuah karya sastra tidak dapat diidentifikasi secara pasti, namun secara umum kesadaran tersebut dapat diidentifikasi terbatas pada halhal yang berkaitan dengan kehidupan, misalnya hakikat hidup, tanggungjawab, hakikat permainan kekuasaan dan politik, dan sebaganya. Sedangkan ekspresi kesadaran yang dirasakan oleh pengapresiasi sastra juga bersifat subjektif atau individual artinya tergantung pada kepekaan, ketajaman nurani, penghayatan, serta penjiwaan pelaku apresiasi sastra. 


\section{d. Fungsi rekreatif}

Yang dimaksud dengan fungsi rekreatif yaitu menyediakan, menawarkan, serta menyajikan hiburan secara jasmaniah maupun rohaniah kepada pelaku apresiasi sastra. Hiburan yang ditawarkan dalam sebuah karya bisa berupa humor, kekonyolan, sindiran, keindahan, dan sebagainya sehingga mampu memberikan kesenangan, keriangan, keantusiasan, keterpukaan kepada pelaku apresiasi sastra.

\section{PENDEKATAN DALAM APRESIASI SASTRA}

Kegiatan apresiasi sastra dapat dilakukan dengan menggunakan beberapa pendekatan yang bermacam-macam. Keanekaragaman pendekatan tersebut ditentukan oleh tiga hal, yaitu pertama tujuan dan apa yang hendak diapresiasi dalam suatu karya sastra, kedua proses apresiasi dilakukan melalui kegiatan seperti apa, dan ketiga landasan teori yang digunakan dalam apresiasi sastra tersebut seperti apa. Pemilihan pendekatan dalam mengapresiasi sastra sangat ditentukan oleh tujuan dari kegiatan apresasi itu sendiri, sebagai contoh apabila seseorang ingin mengapresiasi sastra dan bertitik tolak pada apa yang akan diapresiasi, maka dapat menggunakan pendekatan parafrastis, emotif, analitis, historis, sosiopsikologis, serta didaktis. Berikut akan dijelaskan beberapa pendekatan dalam mengapresiasi sebuah karya sastra.

1. Pendekatan parafrastis. 
Pendekatan parafrastis diartikan sebagai suatu strategi dalam memahami makna yang terkandung dalam sebuah karya sastra dengan cara mengungkapkan kembali gagasan yang disampaikan oleh pengarang dengan menggunakan kalimat yang berbeda (Aminudin, 2014). Adpun tujuan dari kegiatan ini yaitu untuk menyederhanakan kalimat atau kata yang dipakai oleh pengarang sehingga mempermudah pembaca dalam memahami makna yang terkandung dalam sebuah karya sastra. Pada dasarnya, penerapan dari pendekatan parafrastis ini berangkat dari pemikiran bahwa gagasan yang sama yang disampaikan oleh pengarang dapat disampaikan melalui bentuk yang berbeda artinya menggunakan kalimat yang berbeda. Kemudian simbolsimbol yang mengandung makna konotatif dapat diganti dengan lambang atau bentuk yang memiliki makna yang jelas. Selain itu adanya kalimat atau baris yang mengalami penghilangan dapat dikembalikan lagi pada bentuk dasarnya. Sebagaimana kita ketahui bahwa biasanya pengarang menggunakan kalimat yang padat dan singkat. Pengungkapan kembali suatu gagasan yang disampaikan oleh pengarang dengan menggunakan kalimat atau media yang berbeda akan mempertajam pemahaman si pembaca.

\section{Pendekatan emotif}

Pendekatan emotif dalam mengapresiasi karya sastra berarti menemukan unsur-unsur emosi yang terdapat dalam sebuah karya sastra (Aminudin, 2014). Wujud dari emosi yang terdapat dalam karya sastra bisa berhubungan dengan keindahan maupun isi atau gagasan lucu dan menarik yang disajikan dalam karya sastra. Selain itu, wujud emosi dalam 
sebuah karya sastra bisa berwujud gaya bahasa misalnya metaphor, simile, dan setting yang disajikan.

Adanya pendekatan emotif ini didasari oleh beberapa prinsip, yaitu pandangan bahwa karya sastra merupakan bagian dari karya seni agar bisa dinikmati dan mampu memberikan hiburan pada masyarakat atau pembaca. Selain itu, diharapkan pembaca dapat menemukan unsur estetika maupun humor yang terdapat dalam suatu karya sastra. Beberapa contoh pertanyaan yang berkaitan dengan pendekatan emotif yaitu apakah ada unsur estetik dalam suatu karya sastra yang dibaca? Bagaimana cara pengarang menyajikan suatu keindahan dalam sebuah karya sastra? Dan seterusnya.

\section{Pendekatan analitis}

Pendekatan analitis bisa diartikan sebagai usaha memahami gagasan yang disampaikan oleh pengarang serta memahami cara dan sikap pengarang dalam menyampaikan ide, elemen intrinsik serta hubungan antar elemen tersebut sehingga terbangun keselarasan dan kesatuan hingga pada akhirnya terbangun totalitas makna maupun bentuk karya sastra (Aminudin, 2014). Penggunaan pendekatan analtis ini akan membantu pembaca dalam mengenal unsur intrinsik dalam sebuah karya sastra. Proses apresiasi dengan mengguankan pendekatan ini dilakukan dengan membaca teks sastra secara keseluruhan, kemudian membuat pertanyaan seputar unsur intrinsik dalam karya sastra misalnya bagaimann setting, alur, penokohannya, dan sebagainya. Setelah melakukan proses membaca, hal yang perlu dilakukan 
adalah menganalisis setiap unsur karya sastra dan memahami bagaimana mekanisme hubungannya. Kegiatan analisis ini tidak harus meliputi keseluruhan dari aspek yang terkandung dalam karya sastra. Pembaca bisa membatasi analisis hanya pada dua unsur saja misalnya gaya bahasa dan penokohannya.

\section{Pendekatan historis}

Pendekatan historis berarti pemahaman mengenai biografi pengarang, sejarah yang melatarbelakangi terciptanya karya sastra, serta perkembangan kehidupan penciptaan karya sastra tersebut dari zaman ke zaman (Aminudin, 2014). Pendekatan ini dilatarbelakangi oleh prinsip dasar bahwa karya sastra merupakan bagian dari zamannya. Artinya karya sastra pada zaman tertentu bisa jadi memiliki perbedaan, persamaan, serta hubungan dengan karya sastra lain yang berada pada zaman lainnya. Pemahaman mengenai biografi pengarang juga mendasari adanya pendekatan historis ini, sebab hal tersebut berhubungan dengan upaya pemahaman makna yang terkandung dalam sebuah karya sastra.

5. Pendekatan sosiopsikologis

Pendekatan sosiopsikologis ini berkaitan dengan pemahaman terhadap latar belakang kehidupan sosial budaya, kehidupan masyarakat, sikap pengarang terhadap kehidupannya atau zamannya pada saat karya sastra itu diciptakan (Aminudin, 2014). Pendekatan sosiopsikologis ini seringkali rancu dengan pendekatan historis, karena sama-sama memahami hal-hal yang 
berkaitan dengan pengarang,akan tetapi keduanya sebenarna memiliki perbedaan. Dalam pendekatan historis dibahas mengenai biografi pengarang, hubungan karya sastra tersebut dengan karya sastra sebelumnya maupun karya sastra pada umumnya, serta latar belakang sejarah dari terciptanya suatu karya sastra, sedangkan pendekatan sosiopsikologis lebih menekankan pada aspek kehidupan sosial masyarakat pada masa itu, sikap pengarang terhadap lingkungan, serta bagaimana hubungan antara karya sastra tersebut dengan zaman itu.

\section{Pendekatan didaktis}

Pendekatan didaktis merupakan pendekatan yang berusaha menemukan serta memahami gagasan yang disampaikan pengarang, serta tanggapan evaluatif dan sikap pengarang terhadap kehidupan. Gagasan maupun tanggapan evaluative seorang pengarang terwujud dalam suatu pandangan etis, filosofis, agamis, dan mengandung nilainilai yang dapat menumbuhkan dan memperkaya kehidupan rohaniyah pembaca karya sastra. Pendekatan didaktis ini memerlukan daya intelektual, kepekaan rasa, atau sikap dari pembaca karena penemuan nilai dalam karya sastra bersifat interpretatif. Dengan kata lain, pembaca harus memiliki kepekaan rasa serta intelektual agar mampu memahami pesan yang tersirat dari karya sastra. Akan tetapi nilai-nilai yang terkandung di dalam karya sastra tidak semuanya tersirat, namun diungkapkan secara eksplisit oleh pengarang sehingga pembaca tidak kesulitan dalam meafsirkan makna. 


\section{D.ALIRAN DAN TEORI APRESIASI SASTRA}

Adanya berbagai unsur teks sastra yang sangat kompleks, maka terdapat berbagai aliran maupun teori dalam ananisis sebuah teks sastra (Aminudin, 2014). Beberapa aliran dan teori tersebut secara singkat dijelaskan sebagai berikut:

a. Aliran Fenomenologi

Dalam menganalisis sebuah karya sastra aliran fenomenologi lebih menekankan pada aspek makna dan nilai yang terkandung dalam sebuah karya sastra. Agar mampu memahami makna yang terkandung dalam suatu teks sastra, maka pembaca seharusnya memiliki kemampuan untuk memahami realitas yang digambarkan oleh pengarang secara tersurat dalam sebuah karya sastra. Selain itu pembaca harus mampu mengasosiasi dan mengabstraksikan makna dalam sebuah teks sastra dan disertai dengan perenungan terhadap nilai-nilai yang dipaparkan dalam sebuah karya sastra.

b.Aliran Hermeneutika

Menurut aliran hermeneutika, untuk memahami makna yang tergambar dalam sebuah teks sastra maka diperlukan telaah hubungan teks tersebut dengan kehidupan sosial budaya yang melatarbelakangi terciptanya karya sastra tersebut. Aliran hermeneutika bertolak belakang dengan aliran fenomenologi yang berupaya memahami makna puisi melalui transendensi subjektif terhadap realitas yang semata-mata terdapat dalam sebuah karya sastra. Aliran hermeneutika berpendapat bahwa realitas dalam teks sastra tidak dapat dilepaskan dari kehidupan dan waktu. Fokus dari kajian hermeneutika yaitu pada proses penguraian dan 
pemahaman sebuah karya sastra. Dalam hal ini teks karya sastra dipandang sebagai objek estetik dan dianalisis dengan cara pemisahan dari unsur subjek. Proses analisis dari teks tersebut dianggap sebagai interpretasi Hamdi (dalam Anshari, 2009).

c. Aliran Formalisme

Menurut Sudjiman (1990) formalism merupakan aliran kritik sastra yang mementingkan aspek atau pola bunyi serta kata-kata yang formal atau tradisional.

Aliran ini menekankan pada aspek kebahasaan yang terdapat pada karya sastra yang mencakup adanya penyimpangan bahasa, keunikan bahasa, pembangun struktur wacana, serta konvensi yang melatarbelakangi suatu karya sastra. Kaum formalisme hanya memandang sebuah karya sastra dari segi intrinsiknya, terbebas dari faktor sejarah, biografi pengarang / penulis, serta konteks sejarah yang melatarbelakangi karya sastra. Kaum formalis beranggapan bahwa teks sastra merupakan fakta kebendaan yang terbangun atas kata-kata dan menolak anggapan bahwa teks sastra merupakan pencerminan individu maupun gambaran masyarakat. Selain itu, aliran formalism juga menggunakan konsep defamiliarisasi dan deotomisasi yang digunakan untuk mempertentangkan karya sastra dengan kenyataan sehari-hari. Menurut mereka, sesuatu yang sudah akrab dan secara otomatis diserap, dalam suatu karya sastra hal tersebut dipersulit sehingga menjadi asing dan ganjil sehingga pembaca lebih tertarik terhadap bentuk karya sastra (Saleh, 2014). Aliran formalism ini merupakan reaksi terhadap pendekatan sastra yang menganut filsafat positivism 
(aliran Positivistik) yang beranggapan bahwa segala ilmu pengetahuan harus berasaskan fakta yang dapat diamati, sedangkan ilmu pengetahuan tidak didasrkan pada panca indera akan ditolak karena dianggap sebagai spekulasi kosong. Pemikiran kaum positivism ini mempunyai pengaruh yang kuat terhadap ahli sastra.

\section{d. Aliran Strukturalisme}

Aliran strukturalisme memiliki asumsi dasar bahwa teks sastra merupakan keseluruhan yang unsur-unsurnya memiliki peranan yang hakiki, mempunyai koherensi batiniah dan merupakan kesatuan yang bulat. Adapun bagian dari unsur-unsur tersebut memiliki makna sepenuhnya dari makna keseluruhan teks dan pada akhirnya terjadi lingkaran hermeneutika. Aliran Strukturalisme klasik (Strukturalisme Perancis) lebih menekankan pada deskripsi bahasa dalam sebuah karya sastra. Sedangkan strukturalisme Amerika (New Criticism) menekankan pada isi, adanya ambiguitas, serta ironi yang terdapat pada karya sastra. Selain itu, terdapat aliran Strukturalisme Praha yang memiliki pemikiran bahwa aspek tanda merupakan media primer dalam pemaparan dan keberadaannya tidak dapat dilepaskan dari fungsi sosial dan estetik yang dimiliki oleh tanda tersebut. Selain itu yang menjadi kajian dalam telaah sastra yaitu unsur pembaca serta respon dari pembaca.

\section{E.APRESIASI SASTRA DI SEKOLAH DASAR}

Pembelajaran Bahasa Indonesia di sekolah dasar tidak hanya mencakup beberapa skil berbahasa yaitu menulis, 
membaca, berbicara, dan menyimak, akan tetapi juga ada kegiatan apresiasi sastra. Secara umum tujuan pembelajaran Bahasa Indonesia di Sekolah Dasar diarahkan agar mampu meningkatkan kemampuan siswa dalam berkomunikasi secara lisan maupun tulisan serta dapat menumbuhkan apresiasi terhadap karya sastra. Apresiasi terhadap karya di sekolah dasar diwujudkan dengan cara menikmati dan memanfaatkan karya sastra agar dapat memperluas wawasan, menghaluskan budi pekerti, meningkatkan pengetahuan dan keterampilan berbahasa siswa. Selain itu apresiasi sastra bertujuan agar siswa mampu menghargai dan membanggakan sastra Indonesia sebagai khasanah budaya serta intelektual manusia Indonesia.

a. Pembelajaran sastra di sekolah

Pembelajaran sastra di sekolah dasar dilaksanakan melalui empat keterampilan berbahasa, yaitu mendengarkan karya sastra, membicarakan unsur yang terkandung dalam karya sastra, membaca keanekaragamn karya sastra anak, menuliskan apa yang terkandung dalam pikiran, perasaan, dan seterusnya (Zulela, 2012). Dengan mempelajari sastra, diharapkan siswa mampu menghargai orang lain, mengerti hidup, mengerti kesulitan orang lain, memahami orang lain, memahami watak orang lain, serta belajar menghadapi sebuah persoalan karena di dalam sebuah karya sastra disajikan nilai-nilai yang berkaitan dengan kehidupan. Kemampuan bersastra di sekolah dasar juga bersifat apresiatif, karena sastra dapat menanamkan rasa peka terhadap kehidupan. Jika dibandingkan dengan ilmu lainnya, misalnya ilmu kimia, fisika, dan sebagainya 
yang memberikan manfaat bagi manusia dibidang jasmani, sastra lebih menekankan pada aspek rohani atau kejiwaan yang mana sastra mampu memberikan kebahagiaan atau hiburan. Dari beberapa uraian tersebut, maka pembelajaran sastra di sekolah sangat perlu diajarkan sedini mungkin karena dapat dijadikan sebagai titik tumpu pembangunan karakter siswa. Oleh karena itu pembelajaran sastra haruslah menjadi salah satu prioritas yang nantinya akan memiliki kontribusi yang sangat besar dalam perkembangan kepribadian anak.

\section{b.Manfaat sastra dalam pendidikan}

Seagaiamana diuraikan sebelumnya bahwa pembelajaran bahasa Indonesia tidak hanya mencakup skil berbahasa tapi juga bersastra. Sastra merupakan salah satu bagian dari kebutuhan manusia yang terwujud dalam kesenian serta keindahan yang ada di dalamnya. Sastra yang menggunakan bahasa sebagai media merupakan usaha manusia untuk merekam serta mewujudkan pengalaman keindahannya agar manusia lain dapat menikmatinya. Selain itu sastra memberikan hiburan serta kesenangan kepada orang lain. Pembelajaran sastra yang ada lingkup sekolah pada dasarnya memiliki tujuan membina anak di sekolah dasar dalam mengapressiasi sastra sehingga mereka mampu mengembangkan kearifan, kejelian, serta ketelitian untuk mengambil makna kehidupan yang disajikan dalam karya sastra. Dalam konteks pembelajaran sastra, Zulela (2012) berpendapat bahwa sastra perlu diajarkan kepada peserta didik karena memiliki manfaat yang sangat besar, diantaranya: 
1. Sastra mampu menunjukkan kebenaran hidup, artinya sastra mampu memberikan pengalaman dan pelajaran yang berguna yang dapat diambil oleh penikmat karya sastra. Dengan adanya pengalaman dan pelajaran tersebut, diharapkan mempu menjadikan manusia menjadi lebih baik, memahami kehidupan, memahami tanggungjawab, mengerti manusia lain, dan seterusnya.

2. Sastra bermanfaat untuk memperkaya rohani, artinya dengan membaca karya sastra penikmat karya sastra semata-mata tidak hanya memperoleh atau mencari hiburan saja, akan tetapi juga fokus terhadap persoalan yang digambarkan dalam karya sastra, pelukisan watak dan mencari makna yang terkandung dalam karya sastra.

3. Sastra melampaui batas bangsa dan zaman, artinya karya sastra yang ada beratus-ratus tahun lalu masih bisa dinikmati dan digemari oleh penikmat karya sastra pada zaman sekarang, misalnya cerita Mahabarata, Ramayana yang mengandung cerita tentang pengalaman hidup, kesetiaan, penghianatan, dan sebagainya.

4. Sastra mampu mendorong kemampuan santun berbahasa, artinya bahasa yang diungkapkan oleh penyair atau penulis melalui karya sastra mampu dipelajari bahkan diikuti oleh penikmat atau pembaca karya sastra.

5. Sastra mampu menjadikan manusia berbudaya, artinya keindahan, kebaikan, kebenaran yang terkandung dalam karya sastra mampu memberikan dampak 
positif terhadap para penikmat karya sastra misalnya berbudi luhur, disiplin, dan berbudaya.

Selain ada beberapa manfaat yang dapat diambil, karya sastra juga memilki beberapa nilai, diantaranya:

1. Sastra mampu memberikan hiburan, rasa senang, kegembiraan, kenikmatan, imajinasi, pengalaman kepada anak-anak. Adapun implikasi dari kesenangan menikmati dan membaca karya sastra pada akhirnya akan menmbuhkan dan meningkatkan minat baca anak.

2. Sastra memberikan dampak positif terhadap perkembangan bahasa anak, baik secara lisan maupun tulisan. Dengan kebiasaan membaca karya sastra, secara tidak langsung pemerolehan bahasa atau keterampilan berbahasa anak akan meningkat karena kosakata mereka bertambah.

3. Sastra membantu perkembangan kognitif siswa. Perkembangan kognitif dan penalaran siswa secara tidak langsung akan meningkat karena kegiatan apresiasi sastra, misalnya melalui proses membaca, mengamati, merangkum, bahkan mengkritik sastra.

4. Sastra memiliki peranan penting dalam perkembangan kepribadian anak. Cerita yang disajikan maupun watak tokoh dalam karya sastra secara tidak langsung akan memiliki dampak yang positif bagi kepribadian anak, misalnya cara mengendalikan emosi, menumbuhkan sifat rendah hati, penyayang, penolong, dan sebagainya. 
5. Pembelajaran dan penghayatan terhadap karya sastra akan menimbulkan pemahaman terhadap makna yang terkandung dalam karya sastra. Pemahaman ini mencakup unsur intrinsik maupun ekstrinsik sebuah karya sastra. Proses pengahayatan terhadap karya sastra bisa dilakukan dengan menganalisis tema, memparafrasekan puisi, menganalisis cerita drama, dan sebagainya.

\section{c. Kegiatan menulis cerita untuk anak SD}

Sebelum menulis karya sastra anak, perlu memperhatikan hakikat serta hal-hal yang berkaitan dengan karya sastra anak. Pada dasarnya karya sastra anak merupakan sastra yang ditujukan untuk anak-anak, bukan sastra tentang anak. Bahasa, cerita, serta penyajiannya harus ditsesuaikan dengan anak-anak selaku pembacanya. Kegiatan sastra anak menurut Zulela (2012) secara produktif meliputi kegiatan menulis dan berbicara. Kegiatan menulis yaitu menulis karya sastra sesuai dengan jenisnya yaitu fiksi, puisi, dan drama yang sesuai dengan anak SD. Sedangkan kegiatan berbicara merupakan kegiatan menceritakan kembali dengan mengguankan bahasa yang komunikatif dan menyenangkan mengenai isi cerita yang perbah didengar, dibaca, maupun yang ditontonnya, dengan kata lain kegiatan ini dikenal dengan istilah mendongeng. Sehubungan dengan pentingnya pembelajaran sastra di sekolah, terdapat genre sastra yang dapat dijadikan acuan dalam proses pemahaman maupun menulis satra untuk anak. Agar lebih jelas, berikut akan dipaparkan genre sastra 
anak SD kelas rendah dan sastra anak SD kelas tinggi sebagaimana yang dijelaskan oleh Zulela (2012).

\section{Sastra anak SD kelas rendah}

Sastra untuk kelas rendah terdiri dari bermacam genre baik yang berbentuk tulisan maupun yang berbentuk lisan, misalnya berupa lagu-lagu, syair lagu, tembang dolanan, permainan huruf, buku bergambar dan cerita petualangan. Syair lagu merupakan puisi yang dilagukan dan mengandung unsur keindahan dengan menggunakan bahasa sebagai medianya. Baik syair lagu, puisi, memiliki keindahan bahasa lewat permainan bahasa yang dilantunkan, pengulangan kata maupun pengulangan bunyi. Sedangkan di dalam tembang dolanan terdapat nilai-nilai yang berkaitan dengan adat istiadat, budi pekerti, sopan santun, moral, unsur kejenakaan yang memiliki keterkaitan dengan kondisi masyarakat setempat.

Selain puisi, tembang dolanan, syair lagu, terdapat juga sastra anak yang berupa cerita lisan. Sessuai dengan namanya, cerita lisan merupakan cerita yang disampaikan secara lisan. Dalam cerita lisan ini, bisanya disampaikan nilai-nilai yang mengandung unsur mendidik, misalnya mengenai sikap, moral, perbuatan baik, perbiatan buruk, disiplin dan sebagainya. Cerita yang disampaikan orang tua kepada anak atau guru kepada muridnya hendaknya bervariasi, hal tersebut dilakukan untuk menghindari rasa bosan yang mungkin dirasakan oleh anak. 


\section{Sastra anak SD kelas tinggi}

Jenis karya sastra untuk anak SD kelas tinggi (kelas IV, V, dan VI) berupa cerita fiksi, novel, cerpen, fiksi realistic, fiksi fantasi, komik sastra anak, dan fiksi historis. Cerita fiksi anak tidak berbeda dengan karya fiksi orang dewasa, hanya saja cerita yang diangkat dalam fiksi anak berkisar tentang kehidupan anak yang sesuai dengan perkembangan kejiwaan anak, misalnya mencakup emosi, moral, perasaan, dan pikiran yang disajikan melalui cerita dan bahasa yang dapat dipahami oleh anak. Dengan mempelajari cerita fiksi anak, diharapkan anak mampu menikmati cerita fiksi, memahami hal-hal yang berkaitan dengan kehidupan, mampu belajar tentang kehidupan melalui cerita yang disajikan dalam karya sastra. Sedangkan fiksi realistic merupakan cerita fiksi yang mengisahkan kehidupan anak secara nyata. Misalnya kehidupan seorang penambal ban, pemulung, petualangan naik gunung, dan sebagainya. Dengan membaca serta memahami cerita fiksi realistic ini diharapkan anak mampu memahami realitas kehidupan dan menjadikannya sebagai pembelajaran.

Fiksi fantasi merupakan cerita yang menampilkan tokoh, alur, karakter yang masih diragukan kebenarannya. Maksudnya cerita yang disajikan sulit diterima oleh akal, misalnya cerita mengenai kucing yang bisa berkomunikasi atau berbicara denagn manusia, dan sebagainya. Cerita fiksi fantasi dikembangkan dengan menghadirkan dunia lain dan dunia yang sebenarnya. Komik merupakan cerita yang disajikan dengan gambar dan disertai kata-kata sebagai penjelasan, memperdalam penyampaian gambar secara keseluruhan. Sebagaimana karya sastra lainnya, komik bisa 
dijadikan sebagai sarana untuk menyampaikan pesan, pengetahuan, yang dikemas dalam bentuk cerita yang menghibur dan ringan. Fiksi historis merupakan cerita yang mengisahkan peristiwa yang luar biasa yang bersifat historis atau dapat diartikan sebagai gambaran kehidupan di masa lalu. Meskipun namanya adalah fiksi, cerita yang disajikan haruslah sesuai dengan fakta atau kebenaran sejarah. Latar yang disajikan haruslah disesuaikan dengan kondisi di masa lalu, misalnya bentuk rumah, pakaian, jalan, dan sebagainya.

Berikut merupakan penjelasan langkah-langkah menulis karya fiksi untuk anak SD menurut Zulela (2012):

1. Menentukan tema

2. Menentukan tokoh cerita

3. Menuliskan draf alur cerita yang mencakup kapan cerita tersebut berawal, klimaks dari cerita, serta akhir dari cerita tersebut

4. Memilih gaya bahasa atau pilihan kata yang tepat, sederhana, dan mudah dipahami oleh anak SD

5.Mengembangkan cerita, dengan cara mendeskripsikan cerita dengan bahasa yang hidup, menyenangkan, dan disesuaikan dengan isi cerita baik berupa cerpen, cergam, cerita rakyat, dan sebagainya.

6. Meminta masukan dari pembaca

Sedangkan langkah-langkah menulis puisi untuk anak SD dijelaskan oleh Zulela (2012) sebagai berikut:

1. Menentukan tema 
2. Merenung atau mengahyati tentang pesan yang akan disampaikan

3. Memilih kata kunci yang tepat untuk menggambarkan pesan yang akan disampaikan

4. Mengimplementasikan pesan dengan kata yang tepat

5. Memperhatikan tone atau nada (permainan bunyi bahasa)

6. Membaca puisi tersebut dengan cermat, dan diungkapkan

Berikut merupakan contoh puisi anak:

\section{Bunga Mawar}

Karya: Ni Komang Herawati

Bunga mawar oh bunga mawar

Mekar kau kini

Sangat indah rupamu

Batangmu berduri-duri

Saat kupetik kau menusuk tanganku

Tapi aku tak marah

Karena kau harum merekah

Bunga mawar

Kan kusiram setiap hari

Kan ku jaga sepanjang hari

\section{F. GENRE KARYA SASTRA DI SEKOLAH DASAR}

Sebagaimana karya sastra pada umumnya,karya sastra anak memiliki jenis atau genre yang bermacam-macam. Lukens (1999) membagi genre karya sastra anak ke dalam 
beberapa macam, yaitu: realisme, fiksi formula, fantasi, sastra tradisional, puisi, dan sastra nonfiksi.

a. Realisme

Realisme merupakan jenis cerita yang biasanya bertemakan tentang masalah sosial yang dihadapi oleh tokoh dalam cerita. Konflik yang disajikan dalam cerita biasanya seputar tentang kehidupan anak, misalnya akibat suka berbohong, maka tidak akan dipercaya. Karakteristik umum dari realisme yaitu menampilkan tokoh dengan karakter yang menarik serta dikemas dalam latar tempat dan waktu yang memungkinkan. Sedangkan alur yang disajikan dalam cerita dikemas secara sederhana, logis, cerita yang disajikan seolah-olah memang terjadi, penyelesaian konflikpun masuk akal dan mudah dipahami oleh siswa. Realisme dibagi menjadi beberapa jenis yaitu realism tentang binatang, realisme historis, dan realisme olahraga, (realisme tentang tokoh) (Zulela, 2012).

1.Realisme binatang

Realisme binatang meripakan cerita seputar binatang yang bersifat nonfiksi, misalnya habitat binatang, ciri fisik, cara hidupnya, dan sebagainya yang tidak mengandung unsur personifikasi (Nurgiyantoro, 2004). Cerita realisme binatang dapat dikemas dengan cara yang menarik misalnya penjelajahan binatang, cara bertahan hidup, cara berdaptasi dengan lingkungannya, dan sebagainya yang benar-benar terjadi dalam kehidupan binatang. Perlu diketahui bahwa cerita bibatang yang mengandung unsur fiksi misalnya binatang yang mampu berbicara, memiiliki konflik dengan binatang lainnya sebagaimana manusia, sehingga tidak 
realistik dan sulit diterima oleh akal, maka cerita tersebut tidak dikategorikan sebagai cerita realisme binatang.

\section{Realisme historis}

Realisme historis merupakan cerita yang menyajikan peristiwa yang terjadi di masa lampau. Adapun latar yang disajikan dalam sebuah cerita harus dideskripsikan mengikuti kondisi yang terjadi di masa lampau, misalnya bentuk rumah, cara berpakaian, kondisi lingkungan, senjata, peralatan dan sebagainya (Nurgiyantoro, 2004). Acuan pengembangan alur biasanya diambil dari tokoh utama dalam suatu cerita. Contoh cerita sejarah yaitu cerita zaman kerajaan Mataram, Pangeran, Diponegoro, dan sebagainya.

3. Realisme olahraga

Realisme olahraga merupakan cerita yang berkaitan dengan dunia olahraga, baik yang berhubungan dengan pemain olahraga, jenis olahraga, tim olahraga, dan sebagainya. Cerita realisme olahraga dapat disisipkan nilainilai kejujuran, kedisiplinan, menghormati ras atau agama lain, dan sebagainya yang dikemas dengan cerita dan bahasa yang menarik.

b. Fiksi formula

Fiksi formula merupakan cerita fiksi yang berkaitan dengan kehidupan anak dan mengandung rasa penasaran lewat teknik penyajian cerita oleh pengarang. Fiksi formula biasanya bercerita tentang detektif dan misteri, cerita romantis dan cerita serial.

1. Cerita detektif dan misteri 
Cerita detektif dan misteri biasanya menyajikan cerita yang menimbulkan rasa ingin tahu melalui peristiwa atau tindakan yang misterius namun pada akhirnya peristiwa tersebut dapat diselesaikan dengan masuk akal (Nurgiyantoro, 2004). Penyajian alur cerita detektif dan misteri dilakukan dengan hati-hati yang bertujuan untuk menunjukkan kekuatan tokoh utama. Cerita detektif biasanya diakhiri dengan kebahagiaan dari pihak yang benar, hukuman bagi pihak yang salah, penyelesaian suatu masalah, serta pengungkapan sebuah misteri atau kasus.

2. Cerita romantis

Cerita romantic merupakan cerita yang menggambarkan kasih sayang. Perlu diketahui bahwa cerita romantic berbeda dengan romansa atau romance yang tidak dapat diketegorikan sebagai cerita formula karena dalam cerita tersebut penulis lebih memperlihatkan kebebasan imajinasi dan kreativitas dalam mengembangkan suatu cerita (Nurgiyantoro, 2004)

\section{Cerita serial}

Cerita serial merupakan cerita yang diterbitkan secara terpisah namun merupakan satu kesatuan unit. Focus pengorganisasian cerita tersebut dapat dilakukan dengan beberapa cara, pertama novel (cerita) dengan dokumentasi perkembangan tokoh dan dikembangkan dengan alur yang terpisah akan tetapi masih memiliki kemiripan tema. Kedua, novel atau cerita dikembangkan dengan satu tokoh utama akan tetapi ada sedikit perubahan karakter sehingga adanya urutan novel menjadi tidak penting. Ketiga, novel (cerita) yang disajikan dengan tokoh yang konstan dan tidak ada perubahan 
sehingga akan memudahkan anak dalam memahami cerita.

\section{c. Fantasi}

Cerita fiksi fantasi merupakan cerita yang menampilkan tokoh, alur, tema yang kebenarannya masih diragukan baik sebagian cerita maupun keseluruhan cerita. Pada adasarnya cerita fiksi ini ada yang realistic, akan tetapi sebagian ada yang tidak logis dan sulit diterima oleh akal. Contoh dari cerita fiksi yang ditampilkan dalam televise yaitu sinetron Tuyul dan Mabak Yul, cerita mengenai binatang yang dapat bicara selayaknya manusia, dan sebagainya. Fiksi fantasi terdiri dari dua jenis, yaitu fiksi fantasi tinggi dan fiksi sains. Fiksi fantasi tinggi merupakan cerita yang menampilkan tokoh yang meyakinkan dan konsisten. Cerita fantasi tinggi ini biasanya ditandai dengan adanya konflik antara pihak yang baik dan yang jahat. Ending cerita dari fantasi fiksi ini dimenangkan oleh pihak yang baik. Sedangkan fiksi sains merupakan cerita yang spekulatif yang diangkat dari dunia nyata, misalnya terkait dengan permasalahan manusia akan tetapi penyelesaiannya dalam lingkup ilmiah. Unsur penokohan dalam cerita fiksi sains ini tidak terlalu ditonjolkan, cerita fiksi sain lebih mengutamakan konflik misalnya hal-hal yang berkaitan dengan kemanusiaan. Fiksi jenis ini juga dapat dikembangkan dengan menampilkan tokoh manusia robot atau cerita tokoh sejarah yang dapat dijadikan panutan dalam hidup.
d. Sastra tradisional 
Sastra tradisional ini berasal dari tradisi yang tidak diketahui kapan dimulai, siapa penciptanya, kapan waktunya serta dikisahkan secara lisan dan turun temurun. Yang termasuk dalam genre sastra tradisional yaitu fabel, dongeng, legenda, epos, dan mitos.

\section{e. Puisi}

Puisi merupakan karya sastra yang memiliki keindahan baik dari segi bahasa maupun permainan bunyi bahasa. Pilihan kata dalam puisi berkaitan dengan makna dan unsur estetika dalam puisi tersebut. Bahasa yang digunakan dalam puisi singkat, padat akan tetapi kaya akan makna. Selain itu format puisi juga memiliki ciri khas yaitu lebih pendek dibandingkan dengan karya fiksi lainnya. Hal tersebut adakalanya juga bertujuan agar pusi tersebut memiliki keindahan secara visual. Genre puisi anak bisa berupa tembang tradisional, lirik tembang nina bobo, puisi naratif (puisi yang di dalamnya mengandung cerita atau cerita yang dikisahkan lewat puisi), dan puisi personal (Nurgiyantoro, 2004). Perlu diingat bahwa puisi anak disampaikan dalam bahasa sederhana dan umumnya belum menggunakan bahasa kias.

\section{f. Non fiksi}

Karya sastra nonfiksi bisa berupa buku nonfiksi yang berisi tentang informasi yang ditulis secara artistik baik dari segi bahasa maupun gambar yang disajikan sehingga dapat menimbulkan efek yang menyenangkan dan mudah dipahami oleh pembaca (anak-anak). Menurut Nurgiyantoro (2004) tidak semua buku nonfiksi bisa dimasukkan dalam kategori atau jenis karya nonfiksi. Apabila buku nonfiksi tidak memperhatikan keharmonisan bentuk bahasa serta isi 
sebagai sesuatu yang diungkapkan oleh penulis maka buku tersebut bukan termasuk genre non fiksi. Bacaan nonfiksi bisa berupa biografi dan buku informasi. Biografi berisi tentang riwayat hidup seseorang atau tokoh. Penyajian riwayat hidup seseorang tidak dipaparkan secara keseluruhan, akan tetapi dibatasi pada hal-hal tertentu yang menarik untuk diketahui oleh pembaca. Dewasa ini, biografi disajikan dengan bentuk yang beragam, misalnya berbentuk komik yang menarik agar anak-anak lebih tertarik untuk membaca.Sedangkan buku informasi menyajikan beberapa konsep, fakta, dan informasi yang mampu menambah pengetahuan dan menstimulasi rasa ingin tahu pembaca (anak-anak).

\section{G.RANGKUMAN}

a. Apresiasi sastra merupakan suatu kegiatan menggauli karya sastra secara dengan sungguh-sungguh sehingga mampu menumbuhkan pengertian, penghargaan, kepekaan pikiran kritis dan perasaan yang baik terhadap sebuah karya sastra.

b. Apresiasi sastra memiliki beberapa fungsi diantaranya fungsi eksperensial, fungsi informasional, fungsi penyadaran, dan fungsi rekreatif.

c. Beberapa pendekatan dalam mengapresiasi sebuah karya sastra diantaranya pendekatan parafrastis, emotif, analitis, historis, sosiopsikologis, serta didaktis.

d. Apresiasi sastra bertujuan agar siswa mampu menghargai dan membanggakan sastra Indonesia sebagai khasanah budaya serta intelektual manusia Indonesia.

e. Beberapa manfaat pembelajaran sastra di sekolah diantaranya: 
- Sastra mampu menunjukkan kebenaran hidup

- Sastra bermanfaat untuk memperkaya rohani

- Sastra melampaui batas bangsa dan zaman

- Sastra mampu mendorong kemampuan santun berbahasa

- Sastra mampu menjadikan manusia berbudaya

f. Beberapa nilai yang dapat diambil dari karya sastra diantaranya:

- Sastra mampu memberikan hiburan, rasa senang, kegembiraan, kenikmatan, imajinasi, pengalaman kepada anak-anak.

- Sastra memberikan dampak positif terhadap perkembangan bahasa anak, baik secara lisan maupun tulisan.

- Sastra membantu perkembangan kognitif siswa.

- Sastra memiliki peranan penting dalam perkembangan kepribadian anak.

- Pembelajaran dan penghayatan terhadap karya sastra akan menimbulkan pemahaman terhadap makna yang terkandung dalam karya sastra.

g.Langkah-langkah menulis karya fiksi untuk anak SD:

- Menentukan tema

- Menentukan tokoh cerita

- Menuliskan draf alur cerita yang mencakup kapan cerita tersebut berawal, klimaks dari cerita, serta akhir dari cerita tersebut

- Memilih gaya bahasa atau pilihan kata yang tepat, sederhana, dan mudah dipahami oleh anak SD

- Mengembangkan cerita, dengan cara mendeskripsikan cerita dengan bahasa yang hidup, menyenangkan, dan disesuaikan dengan isi cerita baik berupa cerpen, cergam, cerita rakyat, dan sebagainya. 
- Meminta masukan dari pembaca

h. Langkah-langkah menulis puisi untuk anak SD:

- Menentukan tema

- Merenung atau mengahyati tentang pesan yang akan disampaikan

- Memilih kata kunci yang tepat untuk menggambarkan pesan yang akan disampaikan

- Mengimplementasikan pesan dengan kata yang tepat

- Memperhatikan tone atau nada (permainan bunyi bahasa)

- Membaca puisi tersebut dengan cermat, dan diungkapkan

i. Realisme binatang meripakan cerita seputar binatang yang bersifat nonfiksi, misalnya habitat binatang, ciri fisik, cara hidupnya, dan sebagainya yang tidak mengandung unsur personifikasi.

j. Realisme historis merupakan cerita yang menyajikan peristiwa yang terjadi di masa lampau.

$\mathrm{k}$. Realisme olahraga merupakan cerita yang berkaitan dengan dunia olahraga, baik yang berhubungan dengan pemain olahraga, jenis olahraga, tim olahraga, dan sebagainya.

1. Fiksi formula merupakan cerita fiksi yang berkaitan dengan kehidupan anak dan mengandung rasa penasaran lewat teknik penyajian cerita oleh pengarang.

m. Cerita fiksi fantasi merupakan cerita yang menampilkan tokoh, alur, tema yang kebenarannya masih diragukan baik sebagian cerita maupun keseluruhan cerita.

\section{H.BAHAN DISKUSI}

1. Jelaskan apa yang dimaksud dengan apresiasi sastra menurut beberapa ahli! 
2. Diskusikan dengan teman sekelompokmu mengenai jenis karya sastra anak, dan jelaskan karakteristik karya sastra tersebut!

3. Berikan penjelasan mengapa sastra perlu diajarkan di sekolah!

4. Jelaskan hubungan antara pembelajaran sastra dengan perkembangan kognitif siswa!

5. Salah satu manfaat mempelajari sastra yaitu sastra mampu menunjukkan kebenaran hidup. Jelaskan maksud dari pernyataan tersebut!

6. Buatlah masing-masing satu contoh puisi anak, pantun anak, dan cerpen anak! 


\section{DAFTAR PUSTAKA}

Akhadiah, Sabarti, dkk. 1997. Pembinaan Kemampuan Menulis Bahasa Indonesia. Jakarta: Erlangga.

Aminudin. 2011. Pengantar Apresiasi Karya Sastra. Bandung: Sinar Baru Algensindo.

Bloomfield, L. 1995. Bahasa. Jakata: PT Gramedia -Pustaka Utama

Chaer, Abdul. 1994. Linguistik Umum. Jakarta: Rineka Cipta. Chaer, Abdul. 2007. Pengantar Semantik Bahasa Indonesia. Jakarta : PT.Rineka Cipta

Chaer, Abdul. 2008. Morfologi Bahasa Indonesia: Pendekatan Proses. Jakarta: Rineka Cipta

Chaer, Abdul. 2009. Sintaksis Bahasa Indonesia (Pendekatan Proses). Jakarta: PT Renika. Cipta.

Chaer, Abdul. 2012. Linguistik Umum. Jakarta: Rineka Cipta. Chaer, Abdul. 2015. Psikolinguistik:Kajian Teoretik. Jakarta: Rineka Cipta.

Dardjowidjojo, Soenjono. 2008. Psikolinguistik: Pengantar Pemahaman Bahasa Manusia.Jakarta: Yayasan Obor Indonesia.

Effendi, S. 1973. Bimbingan Apresiasi Puisi. Ende Flores: Nusa Indah.

Faruk. 2002. Novel-novel Indonesia Tradisi Balai Pustaka 1920-1942. Yogyakarta: Gama Media. 
Indah, Rohmani Nur. 2008. Psikolinguistik : Konsep dan Isu Umum. Universitas Islam Negeri (UIN) Malang.

Jassin, H.B. 1981. Tifa Penyair dan Daerahnya. Jakarta: Gunung Agung.

Jassin, H.B. 1959. Tifa Penyair dan Daerahnya. Jakarta: Gunung Agung.

Kartono, Kartini. 1990. Psikologi Anak (Psikologi Perkembangan). Bandung: Mandar Maju

Kentjono, Djoko. 1982. Dasar-dasar Linguistik Umum. Jakarta: Fakultas Sastra UI

Kosasih, E. 2008. Apresiasi Sastra Indonesia. Jakarta: Nobel Edumedia

Kridalaksana, Harimurti. 2008 . Kamus Linguistik . Jakarta : PT. Gramedia Pustaka Utama

Lukens, Rebecca, J.1999.A Critical Handbook of Children's Literature. New York. Longman.

Luxemburg.1982.Pengantar Ilmu Sastra. Dick Hartoko (Terj.) Jakarta: Gramedia.

Maksan, Marjusman. 1994. Ilmu Bahasa. Padang: IKIP Padang

Muslich, Masnur. 1990. Garis-Garis Besar Tata Bahasa Baku Bahasa Indonesia. Malang: YA3 
Muslich, Masnur. 2008 . Fonologi Bahasa Indonesia . Jakarta : Bumi Aksara.

Muslich, Masnur. 2012. Fonologi Bahasa Indonesia: Tinjauan Deskriptif Sistem Bunyi Bahasa Indonesia. Jakarta: Bumi Aksara.

Nurgiyantoro.2004. Sastra Anak: Persoalan Genre.

Humaniora.Vol.16.107-122.

Nurgiyantoro, Burhan. 2009. Penilaian dalam Pengajaran Bahasa dan Sastra. Yogyakarta: BFFE-Yogyakarta.

Nurgiyantoro, Burhan. 2009. Teori Pengkajian Fiksi. Yogyakarta: Gajah Mada University Press.

Pateda, M. 1990. Linguistik Sebuah Pengantar. Bandung:Angkasa

Ramlan, M. 1983. Morfologi: Suatu Tinjauan Deskriptif. Yagyakarta: UP Karyono

Ramlan, M. 1987. Morfologi: Suatu Tinjauan Deskriptif. Yagyakarta: CV Karyono

Rosidi, Ajip. 1969. Ikhtisar Sejarah Sastra Indonesia.Bandung: Binatjipta.

Samsuri. 1991. Analisis Bahasa.Jakata: Elangga

Saryono, Djoko. 2009. Dasar Apresiasi Sastra. Yogyakarta: Elmatera Publishing.

Semi, Atar M.1992. Anatomi Sastra. Bandung: Rosda Karya.

Setyawati dkk. 2004. Sastra Melayu Lintas Daerah.Jakarta: Pusat Bahasa Departemen Pendidikan Nasional 
Situmorang. 1983. Puisi dan Metodologi Pengajarannya. Ende Flores: Nusa Indah

Soeparno. 2002. Dasar-Dasar Linguistik Umum.Yogyakarta: PT Tiara Wacana Yogya

Suandi, Nengah, dkk. 2013. Keterampilan Berbahasa Indonesia Berorientasi

Integrasi Nasional dan Harmoni Sosial.

Sudjiman, Panuti. 1988. Memahami Cerita Rekaan. Jakarta: PT.Pustaka Jaya

Sudjiman, Panuti. 1990, Kamus Istilah Sastra, Jakarta: UI Press

Sumardjo, Jakop dan Saini K.M. 1986. Apresiasi Kesusasteraan. Jakarta: Gramedia.

Sumardjo, Saini K.M.1994. Apresiasi Kesusasteraan. Jakarta: Gramedia Pustaka Utama

Sumarjo, Yakob dan Saini K.M. 1997. Apresiasi Kesusastraan. Jakarta: PT Gramedia

Suparno, Yunus. 2007. Keterampilan Dasar Menulis. Jakarta : Universitas Terbuka.

Supriyadi. 2006. Pembelajaran Sastra yang Apresiatif dan Integratif di Sekolah

Dasar. Jakarta: Direktorat Jenderal Pendidikan Tinggi.

Suratno. 2010. Bahasa Indonesia. Jakarta: CV Buana Raya. 
Suyanto, Edi. 2012. Perilaku Tokoh dalam Cerpen Indonesia. Bandar Lampung: Universitas Lampung.

Tarigan, Henry Guntur.1985. Prinsip-Prinsip Dasar

Sastra.Bandung: Angkasa

Tarigan, Henry Guntur. 2011. Prinsip-prinsip Dasar Sastra.

Bandung: Angkasa

Verhaar, J.W.M. 1996. Asas-asas Linguistik Umum. Yogyakarta: Gadjah Mada University Press

Verhaar, J.W.M. 2010. Asas- Asas Linguistik Umum. Yogykarta: Gadha Mada University Pess.

Venhaar, J.W.M. 2012. Asas-Asas Linguistik Umum. Yogyakarta: Gadjah Mada University Press

Waluyo, Herman. 1991. Teori dan Apresiasi Puisi. Jakarta: Erlangga

Waluyo, Herman J. 1995. Teori dan Apresiasi Puisi. Jakarta: Erlangga

Waluyo, Herman J. 2002. Apresiasi Puisi. Jakarta: Gramedia Pustaka Utama.

Wellek, Rene dan Austrin Warren. 1995. Teori Kesusastraan. Melani Budianta (Terj.) Jakarta: Gramedia.

Widjono. 2007. Bahasa Indonesia Mata Kuliah Pengembangan Kepribadian di Perguruan Tinggi. Jakarta: PT Grasindo. 
Winarni, Sri. 2010. Bunga Rampai Pantun.Trawas: TB Pustaka Ilmu

Wiyanto, Asul. 2002. Terampil Bermain Drama. Jakarta: Grasindo

Yudiono, K.S. 2007. Pengantar Sejarah Sastra Indonesia. Jakarta: Grasindo.

Zulela, M.S. 2012. Pembelajaran Bahasa Indonesia. Bandung: Remaja Rosdakarya. 
